\title{
Are Takeover Premiums Really Premiums? Market Price, Fair Value, and Corporate Law
}

\author{
Lynn A. Stout $\dagger$
}

\section{INTRODUCTION}

The acquiring firm in a corporate takeover almost invariably pays an enormous premium over market price for the stock of the target company. ${ }^{2}$ Corporate scholars find this puzzling. ${ }^{2}$ According to the widely accepted theory of the efficient stock market, ${ }^{3}$ the shares of target firms should trade at prices that fully and accurately reflect the value of the firms' assets and expected earnings. ${ }^{4}$ The stock should be worth no less, and no more. As a result, corporate commentators have become preoccupied with explaining takeover premiums. ${ }^{5}$ Many argue that average premiums of fifty per cent must be evidence that acquiring firms expect to substantially improve their targets' earnings and that takeovers promote

† Associate Professor of Law, The George Washington University National Law Center. A.B. 1979, M.P.A. 1982, Princeton University; J.D. 1982, Yale University. I would like to thank Bernard Black, Philip Hamburger, Reinier Kraakman, Saul Levmore, Fred Zacharias, Win Whittaker, and especially William Wang for their helpful comments and suggestions, and Richard Cohn for his research assistance.

1. See Black, Bidder Ozerpayment in Takeovers, 41 STAN. L. Rev. 597, 601 (1989) (takeover premiums averaged 50\% over market in 1980's); Kraakman, Taking Discounts Seriously: The Implications of "Discounted" Share Prices as an Acquisition Motive, 88 Coloum. L. Rev. 891, 892 (1988) (takeover premiums average $50 \%$ ).

2. Sep, e.g., Black, supra note 1, at 598 (source of takeover gains "a continuing puzzle"); Coffee, The Uncertain Case for Takeoter Reform: An Essay on Stockholders, Stakeholders and Bust-Ups, 1988 WIs. L. REv. 435, 443 ("saurce of takeover gains remains a mystery"); Wang, Some Arguments that the Stock Market Is Not Efficient, 19 U.C. Davis L. REv. 341, 398 (1986) (takeover gains "controversial").

3. Sep infra Section I.A. (efficient market theory). See generally Gilson \& Kraakman, The Mechanisms of Markel Efficiency, 70 VA. L. REv. 549 (1984) (same); Stout, The Unimportance of Being Efficient: An Economic Analysis of Stock Market Pricing and Securities Regulation, 87 Mich. L. REv. 613 (1988) (same).

4. As this Article argues, stock prices can fully incorporate all information relevant to rational estimates of earnings and assets without accurately reflecting stocks" "intrinsic value." See infra notes 32-36, 283-320 and accompanying text.

5. The literature debating the source of takeover premiums is vast and growing. See, e.g., R. Gilson, The Law and Finance of Corporate ACQuisitions 255-498 (1986) (more than 200 pages discussing how corporate acquirers extract gains implied by takeover premiums); Black, supra note 1, at 606-34 (explaining premiums); Coffee, Regulating the Market For Corporate Control: $A$ Critical Assessiment of the Tender Offer's Role in Corporate Governance, 84 Colum. L. Rev. 1145, 1162-75 (1984) (same); Kraakman, supra note 1, at 893-908 (same). 
economic efficiency. ${ }^{8}$ Others conclude that acquiring firms must be harming their own shareholders by paying too much for target firms. ${ }^{7}$

Curiously, the burgeoning takeover literature largely overlooks the most straightforward explanation for premiums. ${ }^{8}$ If the bidder who buys a controlling block of shares in a target firm is "cornering the market" in a unique good with a limited supply, it seems natural that buying larger and larger quantities of stock should inevitably bid up the market price. The idea that large stock transactions exert such "price pressure" has intuitive appeal. Investors, underwriters, and corporate managers have long presumed that selling a large block of stock depresses the market price of that stock, while buying a large block raises the price. ${ }^{9}$ Why, then, has the academic literature disregarded that obvious explanation for premiums?

The answer seems to be that most contemporary scholars reject the concept of price pressure because it is inconsistent with modern financial economics. ${ }^{10}$ According to orthodox capital asset pricing theory, ${ }^{11}$ investors should be able to buy or sell very large amounts of any particular stock without changing its prevailing market price. ${ }^{12}$ In economic terms, inves-

6. E.g., Easterbrook \& Fischel, The Proper Role of a Target's Management in Responding to a Tender Offer, 94 HaRv. L. REv. 1161, 1173-74 (1981) [hereinafter Easterbrook \& Fischel, Proper Role] (source of premium is acquirer's ability to use firm's assets more efficiently, so takeovers benefit both shareholders and society); Easterbrook \& Fischel, Corporate Control Transactions, 91 YalE. L.J. 698, 705-06 (1982) [hereinafter Easterbrook \& Fischel, Corporate Control] (acquirers pay premiums in belief they can manage target company more efficiently); see infra notes 128-35 and accompanying text (widely accepted argument that takeovers produce social gains).

7. E.g., Black, supra note 1, at 599 (bidders overpay); Coffee, supra note 2, at 443-44 (premiums constitute wealth transfer from acquiring shareholders); see infra notes 136-39 and accompanying text (overpayment theory).

8. The possibility that takeover premiums reflect nothing more than price pressure has been largely neglected. See infra note 150; see also infra notes 125-39 and accompanying text (reviewing traditional explanations for premiums).

9. R. Brealey \& S. Myers, Principles of Corporate Finance 297 (3d ed. 1988) (corporations and regulatory commissions believe issuing stock lowers price); Asquith \& Mullins, Equity lssues and Offering Dilution, $15 \mathrm{~J}$. FIN. EcoN. 61, 61 (1986) ("Financial executives, investment bankers and many regulators argue that selling equity causes a firm's stock prices to fall."); see infra notes 43-45 and accompanying text (market practices presuming inelastic demand).

10. W. Klein \& J. Coffee, Business Organization and Finance 323 n.29 (3d ed. 1988) (most current scholars reject "older" theory that large transactions alone lead to price changes; demand should be almost perfectly elastic); see, e.g., Carney, Signalling and Causation in Insider Trading, 36 CATH. U.L. REv. 863, 877 (1987) (demand for stocks is perfectly elastic and volume irrelevant to prices); Easterbrook, Insider Trading, Secret Agents, Evidentiary Privileges, and the Production of Information, 1981 Sup. CT. REv. 309, 335-36 (demand for stock should be highly elastic; investors should be able to buy arbitrarily large amounts at market price); Gilson \& Kraakman, supra note 3, at 629-31 (suggestion that large transactions exert pressure on prices by altering supply is erroneous and inconsistent with modern financial theory). The assumption of perfectly elastic demand enjoys similar prominence in the finance literature. Asquith \& Mullins, supra note 9, at 61-62 (finance literature assumes stock demand horizontal, so price is not changed by large transactions); Shleifer, Do Demand Curies for Stocks Slope Down?, 41 J. Fin. 579, 579 (1986) (several important propositions in corporate finance rely on ability of investors to buy or sell any amount of stock without affecting market price).

11. See infra notes $27-40$ and accompanying text (Capital Asset Pricing Model).

12. See R. BReAley \& S. MYers, supra note 9, at 296-98 (modern efficient market theory implies perfectly elastic demand); Kraakman, supra note 1, at 899 n.25 (efficient capital market theory implies horizontal demand function); Shleifer, supra note 10, at 579 (common asset pricing models built on efficient market theory, including Capital Asset Pricing Model, predict horizontal 
tor demand for individual stocks should be "perfectly elastic," and the demand function for shares should be horizontal. ${ }^{13}$

As policymakers increasingly embrace financial theory as a guide to corporate and securities policy, the notion of perfectly elastic demand is being absorbed by, and is changing, the basic structure of corporate law. The belief that takeover premiums reflect efficiency gains rather than simple price pressure has led courts to hold state anti-takeover statutes unconstitutional ${ }^{14}$ and commentators to argue that management of target firms should be precluded from mounting a defense to an unwanted bid. ${ }^{16}$ The assumption that market price is not influenced by large transactions also is crucial to the widely accepted proposition that in an efficient market, the price of a firm's shares is an accurate reflection of the stock's intrinsic value. That proposition has inspired state legislatures to limit dissenting shareholders' rights to appraisal, ${ }^{16}$ and the SEC to undertake a major revision of the Federal disclosure system. ${ }^{17}$

Those are only four examples of the importance of demand elasticity assumptions in corporate law and theory. The presence or absence of price pressure is fundamental to our understanding of both market behav-

demand).

13. See infra note 28 (shape of demand function); infra notes $27-28$ and accompanying text (perfect demand elasticity).

14. E.g., Edgar v. MITE Corp., 457 U.S. 624, 643 (1982) (plurality opinion) (Illinois antitakeover statute struck down as unreasonable burden on commerce; statute blocked tender offers, depriving shareholders of opportunity for premium and harming efficient reallocation of economic resources to their highest valued use (citing Easterbrook \& Fischel, Proper Role, supra note 6)); Dynamics Corp. of Am. v. CTS Corp., 794 F.2d 250, 253, 263-264 (7th Cir. 1986) (takeover at premium prict efficiently moves corporate assets to thase who value them most; striking down Indiana statute under Commerce Clause), affd in part and rev'd in relevant part, 481 U.S. 69, 92 (1987) (noting argument that takeovers reallocate corporate assets "into the hands of management who can use them most effectively"); Fleet Aerospace Corp. v. Holderman, 637 F. Supp. 742, 761 (S.D. Ohio) (injunction entered on likelihood that Ohio anti-takeover statute would be held unconstitutional burden on efficiency-enhancing tender offers), aff d, 796 F.2d 135 (6th Cir. 1986), vacated, 481 U.S. 1026 (1987); Icahn v. Blunt, 612 F. Supp. 1400, 1416 (W.D. Mo. 1985) (Missouri anti-takeover law unconstitutional under Commerce Clause for posing unreasonable burden on acquisitions that improve efficiency and transfer scarce resources to higher valued uses).

15. Sep, e.g., Easterbraok \& Fischel, Proper Role, supra note 6, at 1164 (arguing that target management should acquiesce to all premium demands); Gilson, A Structural Approach to Corporalions: The Case Against Defensite Tactics in Tender Offers, 33 STAN L. Rev. 819 (1981) (same); cf. Bendix Corp. v. Martin Marietta Corp., 547 F. Supp. 522, 542 (D. Md. 1982) (declining to enjoin tender offer, because tender offers reallocate corporate resources to their highest uses, and nationwide effects are substantial); Koenings v. Joseph Schlitz Brewing Co., 123 Wis. 2d 490, 505, 368 N.W.2d 690, 698 (Wis. Ct. App.), rev'd on other grounds, 126 Wis. 2d 349, 377 N.W.2d 593 (1985) (invalidating "golden parachutes" and noting that management faced with takeover should remain passive and refrain from defensive tactics (citing Easterbrook \& Fischel, Proper Role, supra note 6)). See generally infra notes 178-81 and accompanying text (view that target management should not adopt defensive tactics in response to premium bid).

16. A number of states now deny appraisal to dissenting stockholders whose shares are listed on an arganized exchange on the theory that they can simply sell their shares and receive a price that reflects true value. See infra notes $277-83$ and accompanying text (stock market exception to appraisal).

17. The "integrated" disclosure system limits the obligation of large, publicly held firms to provide information directly to investors, on the SEC's explicit assumption that market price already accurately reflects that information. See infra notes $315-17$ and accompanying text. 
ior and the relationship of stock price to value. As a result, demand elasticity also is a critical factor in determining, inter alia, the appropriate regulation of stock "manipulation,"18 the need to limit underwriters' stabilizing purchases, ${ }^{19}$ the economic benefits and harms of insider trading, ${ }^{20}$ the wisdom of the "fraud on the market" theory of investor reliance, ${ }^{21}$ and the legitimacy of investment strategies that rely on efficient market prices as a surrogate for value. ${ }^{22}$ Because assumptions concerning the elasticity of investor demand for stocks are crucial determinants of policy on all these issues, the hypothesis that investor demand is perfectly elastic deserves thorough and critical examination.

The notion of perfectly elastic demand has gained currency because it enjoys theoretical support from the widely accepted ${ }^{23}$ variant of efficient market theory known as the Capital Asset Pricing Model (CAPM) ${ }^{24}$ As in the case of any other economic theory, the validity of the CAPM depends upon the validity of its underlying assumptions. One assumption underlying the GAPM is that investors make identical estimates of the risks and returns of various stocks. Demand is perfectly elastic because at below-market prices all investors agree the stock is a bargain and want to buy it, while at above-market prices all investors perceive the stock as overpriced and want to sell. ${ }^{25}$

Although the assumption of "homogeneous beliefs" was a useful simplifying tool for the pioneers who developed the CAPM, it is pure fiction. If investors did not disagree about the merits of securities, there would not be a stock market. ${ }^{28}$ This Article examines the consequences for corporate doctrine of abandoning the assumption of homogeneous beliefs.

18. See infra note 120 and accompanying text.

19. See infra note 121 and accompanying text.

20. See infra notes $236-40$ and accompanying text.

21. See infra note 314 .

22. See infra notes 304,312 and accompanying text.

23. Sep R. BREAley \& S. MYers, supra note 9, at 163 (CAPM "reigning" pricing model); Gilson \& Kraakman, supra note 3, at 561 n.41 ("widely accepted" CAPM); Gordon \& Kornhauser, Efficient Markets, Costly Information and Securities Research 60 N.Y.U. L. REv. 761, 776 (1985) (CAPM "most prominent" of stock pricing theories). See generally R. BREALEY \& S. MYERS, supra note 9, at 149-99 (describing development and nature of CAPM).

24. The CAPM holds that investors value stocks by looking only at their expected returns discounted by nondiversifiable market risk; that prices in an efficient market will be accurate indicia of stock value as measured by those two factors; and that because investors can choose from among a large number of efficiently priced substitute stocks, there will be no demand to purchase any stock above market price, and infinite demand to purchase below market. See infra notes $27-40$ and accompanying text.

25. See infra note 52 and accompanying text.

26. See Carney, Shareholder Coordination Costs, Shark Repellents, and Takeout Mergers: The Case Against Fiduciary Duties, 1983 A.B.F. REs. J. 341, 385 ("[e]xchanges in securities markets are built [upon] differing expectations [for] future performance of particular firms"); Gordon \& Kornhauser, supra note 23 , at $781 \mathrm{n} .49$ ("differences and changes in beliefs are . . . the occasions for trade"). A certain number of stock transactions can be attributed to investors' changed liquidity preferences-that is, their desire to transform equity into cash, or vice versa. But liquidity needs seem a weak explanation for a stock market in which more than fifty percent of outstanding shares change hands every year. See Stout, supra note 3, at 704 n.450 (secondary market characterized by heavy 
Part I begins by describing the CAPM and the theoretical foundations of the assumption of perfectly elastic demand. Part I then presents an alternate model of stock pricing that recognizes that investor estimates of stock value may differ. In contrast to the CAPM, the "heterogeneous beliefs" model posits that the demand for stocks is downward-sloping. In other words, the market participants are correct-large transactions do change stock prices. Part I reviews the empirical evidence and concludes that it supports that view.

The possibility that trading exerts price pressure in turn suggests a need to reexamine many aspects of corporate law and theory that are premised, explicitly or implicitly, on the assumption of perfectly elastic demand. To illustrate, Part II examines the important policy implications of demand elasticity assumptions in three controversial areas of corporate doctrine: corporate takeovers, insider trading, and stock valuation in the appraisal context. In each of those areas, the possibility that demand is downward-sloping provides a satisfying explanation for market behavior that is difficult to reconcile with the CAPM. More important, it undermines the wisdom of a regulatory scheme increasingly premised on the assumption of perfectly elastic investor demand.

\section{Demand Elasticity: Theories and Evidence}

\section{A. The Perfect Elasticity Hypothesis}

Economists use the phrase "demand elasticity" to refer to the degree to which a change in the price of a particular good changes the quantity demanded by consumers. ${ }^{27}$ Demand is described as "perfectly elastic" when even a slight rise in price causes consumer demand to fall to zero, while a slight price decline causes demand to expand infinitely. Another way to interpret the notion of perfectly elastic demand is to describe the demand function as horizontal. ${ }^{28}$ At market price, investors are indifferent between buying or selling any amount of a particular security. Below market price, everyone wants to buy; above market price, no one wants to.

The hypothesis that investor demand for particular stocks should be perfectly elastic (also called the "horizontal demand" hypothesis) is a necessary corollary of the CAPM. The CAPM, in turn, is premised on two of the most fundamental tools of the modern financial economist: portfolio theory and the theory of the efficient stock market.

Portfolio theory predicts that investors valuing financial instruments like stocks focus primarily on the expected return of their investment, in

\footnotetext{
turnover, with stocks changing ownership on average every other year).

27. See generally R. LiPSEY \& P. SteIneR, Economics 90-99 (4th ed. 1975); P. SAMuelson \& W. NoRdhaus, ECoNomics 423-32 (13th ed. 1989).
}

28. FIGURE 1: 
the form of dividends paid and proceeds upon resale. ${ }^{28}$ Investors are also concerned, however, about variation in return that cannot be eliminated by holding a diversified portfolio. ${ }^{30}$ Because investors dislike such nondiversifiable "market risk," they demand compensation to accept it. They will only buy stocks with a high degree of market risk if those stocks pay a risk premium in the form of higher expected returns. ${ }^{31}$

Efficient market theory predicts that in a well-developed securities market, publicly available information relevant to stock values is so quickly reflected in market prices that, as a general matter, investors cannot ex-

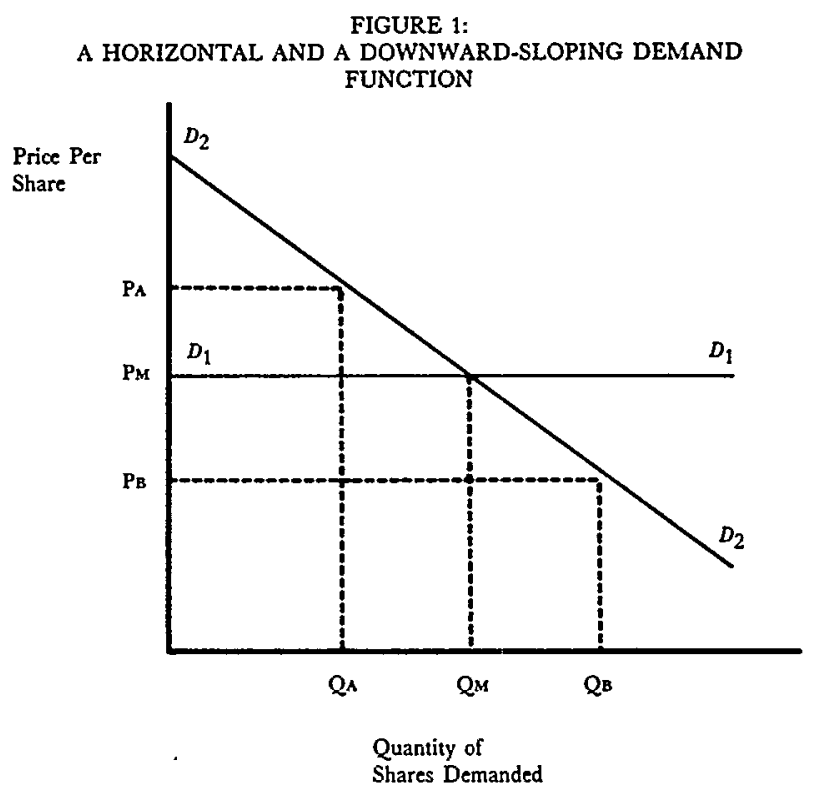

A horizontal demand function for stock is depicted by line $D_{1}-D_{1}$. At market price $\mathrm{PM}_{\mathrm{M}}$ any amount of stock can be bought or sold. At price $\mathrm{PA}_{\mathrm{A}}$, above market, investor demand is zero. At price $\mathrm{PB}$, below market, demand is infinite. A downward-sloping demand function is shown by line $D_{2}-D_{2}$. At $P M$, investors want to buy quantity $Q_{M}$. Raising price to $P_{A}$ reduces demand to $Q_{A}$; decreasing price to $P_{B}$ increases the quantity demanded to QB.

29. See generally R. BREALEY \& S. MYERS, supra note 9, at 125-44. Investors apply a discount to income to be received at a later date, so that future income from dividends and resale price is discounted to present value. Id. at 11-42.

30. Variation in returns is also known as "risk." A stock that pays a $\$ 10$ dividend in its first year and nothing in its second year is "riskier" than a stock that pays a $\$ 5$ dividend in both years. Id. at 125-143.

31. Market or "beta" risk is variation, usually due to macroeconomic factors, that affects all stocks at the same time. Diversifiable or "alpha" risk is variation unique to a particular corporation. Portfolio investors are indifferent to alpha risk, because it is eliminated by holding a diversified portfolio. Id. at 149-99. Investors should only be willing to purchase "high beta" stocks whose nondiversifiable risk exceeds that of a market portfolio if those stocks have higher expected returns, while investors will accept lower-than-market returns from "low beta" stocks whose risk is less than market. Id. at 149-65. 
pect to profit from trading on such information. ${ }^{32}$ The stockholder who decides to sell in response to bad news finds that by the time she has placed her order, the price she can get for her stock has already declined. Similarly, the investor motivated by good news to buy discovers a higher market price already reflects the new information. ${ }^{33}$ Attempts by investors to identify overpriced or underpriced stocks are futile in an efficient market; the shareholder who buys at market price gets exactly what she pays for. ${ }^{34}$

The CAPM incorporates portfolio theory into efficient market theory to predict that, because investors value stocks according to their risk-adjusted returns, stocks with identical estimated levels of market risk should trade at prices that imply an identical estimated rate of return. ${ }^{35}$ Otherwise, one would be a bargain relative to the other-an impossibility in an efficient market. $^{36}$

32. This is the familiar Efficient Capital Markets Hypothesis (ECMH). See Gilson \& Kraakman, supra note 3, at 549-52 (acceptance and importance of ECMH); Stout, supra note 3, at 619-22 (influence of efficient market theory). See generally R. BREALEY \& S. MYers supra note 9, at 279-99 (describing development and nature of ECMH). Differences in the level of information reflected in market prices form the basis for the commonly adopted distinctions among "weak form" efficiency (prices reflect all information concerning past patterns of price changes), "semi-strong" efficiency (prices reflect all published information), and "strong form" efficiency (prices reflect not just public information, but all available information). See id. at 287-88; Gilson \& Kraakman, supra note 3 , at 555-56 nn.24-27 and accompanying text.

33. According to the ECMH, if a stock is underpriced by the market, an investor who buys it can expect returns greater than those to be achieved investing in stocks of other corporations. The resulting profit opportunity induces hoards of investors and analysts to work far into the night, investigating information relevant to stock values. When new information indicates that the value of a stock has changed, they quickly recognize this and bid price up or down accordingly. So speculators' efforts ensure that the market price of securities quickly reflects all available information useful to predicting their value. Of course, in a perfectly efficient market there is no incentive to look for arbitrage opportunities. A minor degree of inefficiency is required to oil the gears of the efficient market machine. See Grossman \& Stiglitz, On the Impossibility of Informationally Efficient Markets, 70 AM. ECON. REv. 393 (1980).

34. This formulation of the ECMH is implicitly premised on homogeneous investor beliefs. If investors have different opinions concerning stock values, the shareholder who buys at market price may get a price that incorporates all available information yet still departs from that particular investor's estimate of the stock's intrinsic value. See infra notes 53-65 and accompanying text (individuals may disagree with market's valuation). In other words, the ECMH suggests that new information is incorporated into prices quickly, to the extent it is incorporated at all. It does not necessarily imply that all information is so fully and accurately digested that market price is always the best indicator of inherent value. See infra notes $283-320$ and accompanying text (market price not necessarily accurate).

Although market efficiency precludes trading strategies based on short-term price changes in response to new information, efficiency does not necessarily prevent careful investors from profiting from long-term analysis. See infra notes 311-20 and accompanying text (heterogeneous beliefs suggest careful analysis can produce profits over long term); see also Gilson \& Kraakman, supra note 3, at 555-56 nn.24-27 (describing tests of market efficiency, which focus on success of short-term trading strategies).

35. Efficient market theory addresses only expected or anticipated returns in light of publicly available information. It may, of course, turn out that one stock does substantially better than another selling at the same price. But their expected returns ex ante are the same.

36. But see supra note 34, infra notes 283-320 and accompanying text (if investor opinions differ, market price based on opinions of lay investor who sets price at margin may incorporate all public information while still departing from expert opinion of value).

A second reason to question the accuracy of market prices is that efficient market theory and portfo- 
The CAPM consequently predicts that in a well developed securities market, potential investors will be able to choose from among a great many stocks bearing identical expected returns for market risk, any one of which serves as a perfect substitute for any other. ${ }^{37}$ This notion of perfect substitutability provides the theoretical foundation for a horizontal demand curve. Suppose that IBM is currently trading at a price that implies a ten percent return on investment. In an efficient market, substitute stocks with identical market risk-including perhaps ITT, GM, and GE-will also trade at prices implying a ten percent return. If the price of IBM increased so that the implied rate of return from buying IBM fell to nine percent, investor demand for IBM would drop to zero. No rational investor would buy stock promising a nine percent return when the same amount of money could purchase perfect substitutes paying ten percent. Similarly, if the price of IBM were dropped so that buying IBM brought an expected return of eleven percent, all investors would want to buy it. What investor would own stocks that pay ten percent when a perfect substitute offers eleven percent?

The notion that any stock should have a large number of perfect substitutes has produced the corporate finance maxim: "seen one stock, seen them all." 38 In other words, in an efficient market a rational investor should be indifferent between purchasing $\$ 100$ of IBM, or $\$ 100$ of ITT. Many corporate commentators expressly adopt the view that stocks are perfect substitutes for each other and demand accordingly is perfectly elastic. $^{39}$ Others appear to take this for granted in their analysis. ${ }^{40}$

lio theory are not necessarily interdependent. It is possible to have a market that is "efficient" in the sense that prices quickly incorporate information, but have stock prices determined by something other than rational estimates of risk and return. Some argue that efficient markets price stocks in accordance with information concerning irrational investor preferences. Professor Wang has labeled markets that are efficient in this sense as "information arbitrage efficient" rather than "fundamental value efficient." See Wang, supra note 2, at 343-49. Professors Gordon and Kornhauser similarly distinguish between "speculative efficiency" and "allocative efficiency." See Gordon \& Kornhauser, supra note 23, at 826-30 (noting that legal literature usually assumes speculative and allocative efficiency go together, but this is not necessarily true).

37. The number of available substitutes expands still further if we consider the CAPM's prediction that the relationship between a particular stock's degree of nondiversifiable risk and the risk premium it pays should be linear. See Lintner, The Valuation of Risk Assets and the Selection of Risky Intesiments in Stock Portfolios and Capital Budgets, 47 REv. ECON. \& STAT. 13 (1965); Sharpe, Capital Asset Prices: A Theory of Market Equilibrium Under Conditions of Risk, $19 \mathrm{~J}$. FrN. 425 (1964). If that is true, investors can achieve any desired level of risk through some combination of a market portfolio and lending or borrowing at the risk-free rate. Thus, even stocks with differing levels of risk can function as perfect substitutes for each other and all stocks should trade at the same "risk-adjusted" rate of return. See Asquith \& Mullins, supra note 9, at 61-62 (substitutes for stocks with particular risk and return either available directly in efficient market or can be constructed through combinations of existing securities); see also R. BREALEY \& S. MYERS, supra note 9, 136-40 (linear relationship of risk to return under CAPM). Of course, this model is limited by its questionable assumption that investors have unlimited ability to lend or borrow at the risk-free rate. See id. at 163 (unlimited borrowing assumption).

38. R. Brealey \& S. MYers, supra note 9, at 296.

39. See, e.g., Carney, supra note 10, at 865-66, 877, 886-89 (arguing that insider trading does not harm bidding firms because demand is perfectly elastic); Easterbrook \& Fischel, Proper Role, supra note 6, at 726-27 (arguing that takeover premiums must benefit target shareholders because 
To the layman, however, the idea of perfect substitutability is counterintuitive. ${ }^{11}$ After all, IBM and ITT are very different firms, with different products, management, and prospects. The theoretical consequence of perfect substitutability - perfectly elastic demand-also seems somewhat odd. Consumer demand for goods other than securities usually displays some degree of inelasticity. Price hikes reduce the quantity demanded by consumers but do not eliminate demand entirely; price cuts spark additional purchases, but to a limited degree. ${ }^{42}$

The layman's uneasiness about perfectly elastic demand is mirrored by the refusal of those who participate in securities markets to behave as if large stock transactions do not influence prices. Corporations repurchase their own shares in order to raise prices, ${ }^{43}$ underwriters sell stock issues at below-market prices in the belief that this is necessary to sell large amounts of equity successfully. ${ }^{44}$ An even more dramatic example of market behavior inconsistent with perfectly elastic demand is the willingness of takeover bidders to pay large premiums over the market price for the stock of target firms. If purchasers can buy any amount of a particular

investors share homogeneous beliefs and there is no price pressure); Gilson \& Kraakman, supra note 3 , at 629-31 (arguing that because demand is perfectly elastic, insider trading moves prices only sporadically); se' also authorities cited infra note 124. But see Booth, Management Buyouts, Shareloulder Welfare, and the Limits of Fiduciam Duty, 60 N.Y.U. L. REv. 630, 635, 638 \& n.28 (explicitly assuming downward-sloping demand in limited context of buyout); Carney, supra note 26, at 354-57 (positing upward-sloping "supply" curve in takeover context); Coffee, supra note 2, at 1185 (same). Sep generally Levmore, Efficient Markets and Puzzling Internediaries, 70 VA. L. REv. 645, 653-54 (1984) (noting theoretical support for perfectly elastic demand, but suggesting question unresolved).

40. Sie, ex., Fischel, Efficient Capital Market Theory, the Market for Corporate Control, and the' Regulation of Cash Tender Offers, 57 TEx. L. REv. 1, 19, 23 (1978) (because market price is equivalent to share value in efficient market, tender offers above market price will rarely be "inadequate"); Gilson, supra note 15, at 841-42 (theory of efficient market implies takeover at premium is necessarily elficient); Jarrell \& Bradley, The Economic Effects of Federal and State Regulations of Cash Tender Offers, 23 J. LAw \& ECON. 371, 402 (1980) (assuming without discussion that market price is capitalized value of all securities, so that takeover premiums represent newly created wealth rather than price pressure); Comment, Valuation in the Context of Share Appraisal, 34 Emory L.J. $117,119,145-46$ (1985) [hereinafter Comment, Valuation] (only one correct price because stock market prices shares at exactly their intrinsic value).

Occasionally, commentators implicitly assume inelastic demand. See, e.g., Seligman, Reappraising the Appraisal Remedy, 52 Geo. WasH. L. Rev. 829, 838 (1984) (noting possibility that forcing dissenting shareholders to sell their shares on the market may depress prices); Note, Auctioning New Issues of Corporate Securities, 71 VA. L. REv. 1381, 1383-89 (1985) (discussing securities auctions in which lowering price increases demand and bidders' estimates differ).

41. See Carney, supra note 26 , at $357 \mathrm{n} .71$ (perfectly horizontal demand "is intuitively troubling, at the least").

42. This is because perfect substitutes are not available for most goods. For example, consumers may even prefer one brand of an otherwise fungible commodity over another.

43. Booth, supra note 39 , at 635 .

44. Asquith \& Mullins, supra note 9, at 61 (executives and investment bankers believe issuing equity depresses price); of. R. BREALEY \& S. MYERS, supra note 9, at 297 (corporations believe that selling stock depresses price); Scholes, The Market for Securities: Substitution Versus Price Pressure and the Effects of Information on Share Price, 45 J. Bus. 179, 180 (1972) (public utility regulators believe new issues must be underpriced to be successfully sold); Note, A Reconsideration of the Stock Markt Exception to the Dissenting Shareholder's Right of Appraisal, $74 \mathrm{MrCH}$. L. REv. 1023, 1046 (1976) (accepted for purposes of tax valuation that sale of large block of shares depresses price). 
stock without driving price upward, there seems no reason for takeover bidders to pay more than market. ${ }^{45}$

If only because of the large amounts of money involved, it is improbable that market participants' beliefs reflect either a foolish reliance on folklore or an unwillingness to keep abreast of the financial literature. More likely, their opinions are based on their own experience in financial transactions. Indeed, one appellate opinion has gone so far as to suggest that "any person having rudimentary knowledge of securities trading would realize that a course of purchasing stock would tend . . . to increase the price of the stock." 48

The CAPM is far and away the currently dominant stock pricing theory. ${ }^{47}$ But at least on the question of demand elasticity, theory directly conflicts with practice. That discrepancy suggests a need to reexamine the theory.

\section{B. The Heterogeneous Beliefs Hypothesis}

The CAPM was developed by economists during the 1950's and 1960 's. $^{48}$ In the decades since, it has been enthusiastically adopted by legal scholars as well. Law review articles are replete with references to the CAPM and its implications, ${ }^{40}$ and even judicial opinions now use modern financial theory. ${ }^{\text {so }}$ But, as some commentators have observed, "[i]t may be only a slight overstatement to say that only in the legal literature is GAPM considered an accurate account of market processes."'s1

45. Perfectly elastic demand implies that the minimum cost of acquiring all the stock of a firm with a single class of stock can be calculated by simply multiplying the currently prevailing price for one share by the total number of shares outstanding. The willingness of takeover bidders to pay premiums of $50 \%$ or more over this minimum is quite anomalous. See infra notes 125-50 and accompanying text (controversy over sources of premiums); Carney, supra note 26, at 355-56 (if demand is perfectly elastic, all target shareholders should want to sell at any price above market; bidders clearly do not believe shareholders have identical opinions of value); Fisher \& Lande, Efficiency Considerations in Merger Enforcement, 71 CALIF. L. Rev. 1580, $1618 \mathrm{n} .144$ (1983) (according to CAPM, all stocks have perfect substitutes, therefore no need for bidder to offer premium).

46. Alabama Farm Bureau Mut. Casualty Co. v. American Fidelity Life Ins. Co., 606 F.2d 602, 611 (5th Cir. 1979).

47. See authorities cited supra note 23; Gilson, Value Creation by Business Lauyers: Legal Skills and Asset Pricing, 94 YALE L.J. 239, 251 n.28 (1984) (referring to "standard" CAPM); Miller, Risk, Unceriainly, and Dizergence of Opinion, 32 J. Fin. 1151 (1977) ("now-standard" CAPM); Wang, supra note 2, at 349 n.26 ("frequently used" CAPM).

A competing stock pricing model which has attracted some attention is the "arbitrage pricing model." R. Brealey \& S. MYers, supra note 9, at 163-64; Wang, supra note 2, at 373 n.85 (discussing "controversial" arbitrage model). Like the CAPM, the arbitrage model is also premised on homogeneous investor beliefs and so predicts a horizontal demand curve. Gilson, supra, at 252 \& n.33 (homogeneous beliefs assumed in arbitrage models); Shleifer, supra note 10, at 579 (like CAPM, arbitrage model predicts horizontal demand).

48. See Lintner, supra note 37; Markowitz, Portfolio Selection, 7 J. FIN. 77 (1952); Sharpe, supra note 37.

49. Sep Gilson \& Kraakman, supra note 3, at 549-50 (discussing role of financial theory in academic literature).

50. Id. at 550 \& n.5 (providing examples of judicial use of efficient market theory).

51. Gordon \& Kornhauser, supra note 23, at 765 (emphasis in original); $c f$. Gilson \& Kraakman, supra note 3, at 550 (legal culture's "remarkably rapid and broad acceptance of [modern financial 
Like all economic models, the CAPM is premised on a number of assumptions concerning investor tastes and behavior. One of those assumptions is that investors share similar opinions of stocks' values. ${ }^{52}$ The assumption of homogeneous beliefs provides the foundation for the claim of perfectly elastic demand. Because all investors agree that a stock is worth exactly its market price, at below-market prices all investors view the stock as a bargain and rush to buy it, while at above-market prices all investors see the stock as overpriced and are unwilling to purchase any shares.

The assumption of homogeneous beliefs is at adds with a reality in which investors and analysts differ sharply in their predictions for particular corporations, industries, and the general economy. Individuals have different information, different investment experience, and different psychological perspectives from which they evaluate any stock's prospects. Because valuing stocks requires investors to apply their varying backgrounds and talents to predicting an uncertain future, ${ }^{\text {s3 }}$ their estimates of stock value may differ widely. Where one investor predicts that a new line of business will treble a firm's earnings, another believes the venture is doomed to failure; where one shareholder happily tenders her shares in response to a premium offer, another refuses, deeming the price inadequate..$^{\mathrm{ss}}$

The CAPM's assumption of homogeneous beliefs, although originally a useful simplifying tool, is artificial. Financial economists have begun to develop stock pricing models that relax the assumption of homogeneous beliefs and recognize that investors have differing opinions of stock value. ${ }^{38}$ Those models provide an account of demand elasticity in financial markets that differs dramatically from the CAPM's.

The CAPM's tenet that investors should regard different stocks as per-

theories] that did not even exist twenty years ago is not matched by an equivalent degree of understanding").

52. Investors are assumed to value stocks by their expected risk-discounted return and to agree in their estimates of what those risks and returns will be. Gilson, supra note 47, at 252; Gordon \& Kornhauser, supra note 23 , at 781 n.49; Miller, supra note 47 , at 1151.

53. Sep Carney, supra note 26, at 356-57 (arguing that investors' differing expectations for future account for most differences in subjective valuation).

54. Baysinger \& Butler, Anti-takeoter Amendments, Managerial Entrenchment, and the Contractual Theory of the Corporation, 71 VA. L. REv. 1257, 1283 (1985); Gilson, supra note 47, at 253, 262; Miller, supra note 47, at 1151-52; cf. Brudney, Efficient Markets and Fair Values in Parent Subsidiary Mergers, 4 J. CORP. L. 63, 75-77 (1978) (professional appraisers disagree in estimates about future of firms).

55. See Carney, supra note 26, at 357 n.73 (citing Singer v. Magnavox Co., 380 A.2d 969, 971 (Del. 1977) in which only $84 \%$ of shares were tendered in response to unopposed tender offer at premium of $94 \%$ over market price).

56. See Miller, supra note 47; at 1152-53 (predicting downward-sloping demand); Mayshar, On Divergence of Opinion and Imperfections in Capital Markets, 73 AM. EcoN. REv. 114 (1983) (developing pricing models assuming heterogeneous beliefs); Holcombe \& Saba, The Effects of Heterogeneous Expectations on the Capital Siructure of the Firm, 51 S. Econ. J. 356 (1984-85) (expanding Edward Miller's model of heterogeneous expectations and predicting downward-sloping demand function). 
fect substitutes for each other no longer holds true under a stock pricing model that assumes heterogeneous investor opinions of stock value. Instead, investors should have preferences for buying those stocks they believe are "underpriced" by the market, and aversions to buying stocks they perceive to be "overpriced." Particular securities will tend to be held by those individuals who subjectively value them most highly. ${ }^{\mathrm{Bz}}$

That observation has important implications for the likely elasticity of demand for stocks. When the market price of the stock is low, a large number of investors may believe it to be a "good value" relative to other stocks and choose to buy it for their portfolios. As the price rises, the number of shareholders who subjectively value the stock at market price or above will shrink. But even at very high prices, a small number of "super-optimists" will want to buy shares. ${ }^{58}$

The question naturally arises why, if an investor values a particular stock more highly than its market price, that investor does not buy until she has bid the price up to her own optimistic valuation. ${ }^{5 \theta}$ If investors were not risk averse, and if they had infinite wealth or unlimited ability to borrow, the entire stock of a particular firm might indeed end up being owned by that single investor whose view of the firm's future was most optimistic. $^{\text {60 }}$

Investors' resources and credit are limited, however. Few individuals enjoy the wealth needed to own an entire firm. Moreover, the more an individual invests in a single stock, the less she can reduce the riskiness of her investments by diversifying. The risk-averse investor is loath to put all her eggs in even the most attractive basket. Although she may consider a particular stock to be significantly underpriced, at some point the benefits of buying more of it are no longer enough to compensate her for the increased risk of concentrating her portfolio. She will stop buying the stock

57. Suppose two stocks, $A$ and $B$, are both trading at $\$ 40$. Investor $X$ believes that $A$ is correctly priced but that $B$ is really worth $\$ 45$. Investor $Y$ disagrees. $Y$ thinks $\$ 40$ is the correct price for $B$ but believes $A$ is underpriced and really worth $\$ 45$. Because investor $X$ has a certainty (in his view) of making a $\$ 5$ profit on every share of $B$ he buys, he will sell his shares in A to buy more $B$. Meanwhile, Investor $\mathrm{Y}$ will, for the same reasons, sell her shares of $\mathrm{B}$ to buy stock $A$. Eventually, $\mathrm{X}$ will end up owning only B, while Y owns only A. Cf. Friend, Westerfield \& Granito, New Ervidence on the Capital Assel Pricing Model, 33 J. Fin. 903, 903-04 (1978) (discussing studies finding proportion of portfolios highly undiversified and offering heterogeneous investor expectations as plausible explanation).

58. See Miller, supra note 47 , at 1154 .

59. See Carney, supra note 26, at 356-57 (posing question and suggesting that highest-valuing investors may prefer to diversify); see also Easterbrook \& Fischel, Corporate Control, supra note 6, at 726-27 (posing question).

60. See supra note 57 . 
although she still perceives it to be underpriced. ${ }^{61}$ To induce such an investor to purchase more, the price of the stock must be lowered further. ${ }^{62}$

The conclusion of this analysis is that it no longer makes sense to believe that investor demand for a particular stock is nonexistent at prices above the current market price and infinite at prices below. Even at very high prices, a small number of investors may be willing to buy the stock. Lowering price increases demand, both because individuals who do not presently own the stock decide to buy it and because existing shareholders demand additional shares. Investor demand for stocks is not perfectly elastic: incremental changes in price produce incremental changes in quantity demanded.

The concept of less-than-perfectly elastic demand can be depicted as a downward-sloping function. ${ }^{63}$ That function plots the subjective estimates of value that the market attaches to an additional share of a particular stock as a function of the number of shares of that firm already outstanding and held by investors. From the perspective of a seller, investor demand to buy the stock is downward-sloping. For example, a corporation issuing additional equity must continually lower prices to spark additional purchases. ${ }^{64}$ From the perspective of a buyer, the supply function for outstanding shares is upward-sloping. ${ }^{60}$ The takeover bidder who wishes to purchase the stock of a target firm from its current shareholders must offer a price that meets or exceeds the shareholders' varying subjective estimates of value. Thus, purchasing larger and larger amounts requires the bidder to offer higher and higher prices.

Heterogeneous beliefs and risk aversion clearly imply that investor demand for particular stocks (or, from the perspective of a buyer, investor willingness to supply outstanding stock) is not perfectly elastic. By making some reasonable assumptions concerning the total amount of stock outstanding and the probable distribution of individuals' estimates of value, we can draw inferences concerning the degree of inelasticity or "steepness" of the demand function and the nature of equilibrium prices. The resulting model of investor demand is referred to herein as the "heterogeneous beliefs" or "downward-sloping demand" hypothesis. That model

61. Cf. Coffee, supra note 5, at 1188 ("[w] rejected substantial takeover premiums and yet may have shown no desire to purchase additional shares of the same corporation"; suggesting reasons for this, including wealth limitations and desire to diversify portfolio).

62. Lowering stock price provides an additional "risk premium" which compensates for reduced diversification. See Holcombe \& Saba, supra note 56, at 358; Miller, supra note 47, at 1159-60. This analysis suggests that the individual demand functions of even optimistic investors are downwardsloping. Because total market demand is nothing more than the sum of individual demand curves, the aggregate demand function must be downward-sloping as well. Id.

63. Set supra note 28 (Figure I).

64. See generally Miller, supra note 47, at 1151-54 (downward-sloping demand curve).

65. See Carney, supra note 26, at 354-57 (positing upward-sloping "supply curve" that bidder might face in limited context of takeover, as opposed to normal horizontal "demand curve"); Coffee, supra note 5, at 1184-85 \& n.110 (positing upward-sloping supply curve faced by bidder). 
carries implications for market behavior that differ in dramatic and important ways from the CAPM, even beyond the obvious implication that large transactions should exert price pressure.

First, the heterogeneous beliefs hypothesis indicates that the market price for any particular stock is likely to be higher than the average investor's estimate of its value. ${ }^{68}$ Corporations issue only limited amounts of stock. Because the supply of outstanding shares in any particular corporation is accordingly restricted, any single firm's shares are likely to be held by only a small fraction of the investing population. ${ }^{67}$ Practical and legal constraints on the use of "short sales"68 ensure that that subset will consist mainly of those investors who are most optimistic about the company's future. ${ }^{69} \mathrm{~A}$ market price set by the subjective valuation of the leastoptimistic member of this optimistic subset of investors is still likely to exceed the average investor's estimate of value. ${ }^{70}$ The heterogeneous beliefs hypothesis therefore predicts that most stocks will be "overpriced" relative to the investing population's average opinion of their value.

66. That possibility is explored in Edward Miller's pioneering article. Miller, supra note 47, at 1153-54.

67. In the short run, the supply of outstanding stock in any particular firm is fixed. The supply limit can consequently be viewed as a vertical line intersecting the demand curve at whatever fixed quantity of stock is currently outstanding. See infra note 75 (Figure 2); Miller, supra note 47, at 1152 (Figure 1, showing vertical supply function).

68. Short sellers sell "borrowed" stock, temporarily increasing the supply of stock on the market and depressing prices. However, short selling is rare, both because of legal restrictions and because it carries great risk. Short sales are only allowed when the current price of the stock is higher than the last reported price, precluding short sales in times of falling prices. Jarrow, Heterogeneous Expectations, Restrictions an Short Sales, and Equilibrium Asset Prices, 35 J. Fin. 1105 (1980). Moreover, most institutional investors cannot legally sell short. Miller, Bounded Efficient Markets: A New Irinkle to the EMH, $13 \mathrm{~J}$. PorTrolio MGMr. 4, 6 (Summer 1987). Finally, the profits of short selling are limited to the price the seller receives when he "shorts" the stock, while the risk of rising stock price is unlimited. Id. (unlimited upside risk to short selling).

Perhaps more important, a short seller who thinks that the market price for a stock is inflated will only be tempted to sell the stock short if she anticipates that in the near future the market will recognize the stock is overpriced. In other words, short selling can only correct an overoptimistic market valuation if the short seller has reason to believe the market will soon see the error of its ways. If the optimists continue to be optimists, prices will not fall, and the short seller will lose money.

Of course, the optimists who "go long" on stock also face the risk that the market will not come to agree with their judgment. Investors who purchase stock directly, however, can opt simply to hold it until their judgment is vindicated. In contrast, short sellers are obligated to liquidate their positions either on a specific date or, most commonly, whenever the lender demands. K. GARBADE, SECURITIES MARKETS 140 (1982).

69. Holcombe \& Saba, supra note 56, at 366 (price of stock determined by small fraction of investing population who view it most optimistically); Mayshar, supra note 56, at 116, 123 (when short sales are restricted and investor opinions are diverse, number of active investors in particular stock will be subset of potential investors); Miller, supra note 47, at 1153 n.3, 1166 (number of investors who own any particular stock is small relative to universe of potential investors, implying that demand for security comes from those who have most optimistic expectations).

70. Consider a firm, A, with three shares of stock outstanding. There are ten potential investors in $A$, each of whom -could purchase one share. Investor 1 thinks A's stock is worth $\$ 1$, Irvestor 2 thinks $\$ 2$, Investor 3 thinks $\$ 3$, and so forth up to Investor 10 , who believes A's stock is worth $\$ 10$. The "average" investor estimate is $\$ 5.50$. But the market price for $A$ will be $\$ 8$. This is because $A$ will end up being owned by Investors 10,9, and 8-the three most-optimistic investors. Anyone who wants to buy a share of A must be prepared to pay a price sufficient to induce Investor 8 (the least optimistic of the three shareholders) to sell. 
That prediction carries an important caveat. In a world of heterogeneous investor opinions based on differing degrees of knowledge, sophistication, and skepticism, there is no reason to assume that the average of opinions held within the investing population is necessarily the most accurate measure of stock value. ${ }^{71}$ Investors as a whole may under- or overestimate the value of a particular stock if they lack information or succumb to sweeping market tides of bullishness or bearishness. ${ }^{72}$ When average investor opinion is unduly pessimistic, the opinions of the optimists who own a particular stock may be more accurate measures of the value of that security than the opinions of the rest of the herd. ${ }^{73}$ The heterogeneous beliefs model's prediction that most stocks are likely to be overpriced relative to average opinion, therefore, is not necessarily a prediction that stocks are overpriced relative to value.

A second implication of the heterogeneous beliefs model is that the slope of the demand function should increase as it approaches the vertical axis. In a world where potential investors value stocks on the basis of differing information, experience, and psychological perspectives, individuals' subjective expectations for stock performance will vary. Nevertheless, potential investors' estimates of stock value should cluster around some average expectation reflecting the average investor's information, experience, and psychology. Assuming that deviations from that average are random in nature, estimates of stock value within the investing population may be thought of as having a "normal" distribution. ${ }^{74}$ Estimates will tend toward the mean, with the number of outlying opinions decreasing as those opinions become more and more divergent from the mean valuation.

The result is an investor demand function that is convex to the origin, ${ }^{75}$ resembling the classic " $\mathrm{C}$ "-shaped demand curve of basic economics

71. See infra notes 287-304 and accompanying text (discussing relationship of average opinion and market price to value).

72. Sep infra notes 302-04 and accompanying text (average investor opinion may be inaccurate and investors as a whole may under-or over-value stocks).

73. See infra note 297 and accompanying text (optimistic shareholders who exercise appraisal rights may have more accurate opinions of value than market).

74. See Holcombe \& Saba, supra note 56, at 359 (suggesting normal distribution of investor opinion); Miller, supra note 47, at 1152 (suggesting investor opinion is dispersed in unbiased fashion).

75. FIGURE 2: 
texts. ${ }^{76}$ At the margin, the demand function is relatively "flat," so that transactions exert only modest pressure on prices. As the demand function approaches the origin, it becomes steeper. In other words, large numbers of the stock's current shareholders may value their stock at the market price or just slightly above. Those shareholders will be willing to sell for a modest premium. A significant minority, however, will refuse to sell their shares unless they receive a large premium, and a handful of wild optimists may demand two or three times the market price. ${ }^{77}$ Thus, as an acquirer "works his way up" the demand function by buying more and

FIGURE 2:

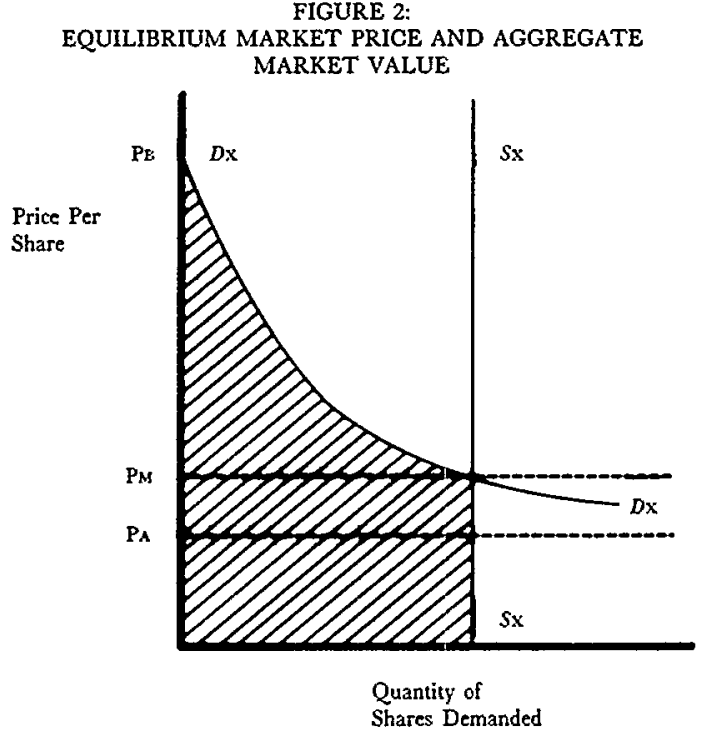

In the short run the total amount of stock available in Firm $X$ is fixed and supply function $S x-S x$ is vertical. Equilibrium price $P M$ occurs at the intersection of $S \mathrm{x}-S \mathrm{x}$ and demand function $D \mathrm{x}-D \mathrm{x}$. PM is higher than the average investor's estimate of PA.

Because the shareholders of Firm X make differing estimates of the value of the firm's shares, they have differing reservation prices at which they are willing to sell. Market price PM is set by the most pessimistic of X's current shareholders. But the buyer who wants to purchase all the outstanding shares of $\mathrm{X}$ must buy from shareholders with higher estimates, paying higher prices as he works his way up the demand curve. The last share of $\mathrm{X}$ must be bought from the most-optimistic shareholder whose subjective estimate of stock value is $\mathrm{PB}_{\mathrm{B}}$. The total market value of all of X's shares, as measured by the price the current owners would require to part with the shares, is the shaded area under the demand curve. $D \mathrm{x}-D \mathrm{x}$.

76. See P. Samuelson \& W. Nordhaus, supra note 27, at 59 (illustrating convex demand curve).

77. The same holds true for the distribution within the investment community of pessimism concerning a particular stock's likely performance. Restrictions on short sales, however, limit the pessimists' ability to influence price. See supra notes 68-69 and accompanying text. 
more stock, the premium he must offer to acquire additional shares increases exponentially. ${ }^{78}$ As discussed below, empirical evidence suggests that investor demand for stocks on average displays roughly "unit" elasticity consistent with a convex demand function whose slope increases as it approaches the origin. ${ }^{79}$

Finally, the heterogeneous beliefs hypothesis contradicts the CAPM's tenet that firms with identical expected earnings and risk should necessarily trade at identical prices. ${ }^{80}$ According to the heterogeneous beliefs model, market prices set by an optimistic minority of potential investors tend to be higher than the average investor's estimate of value. ${ }^{81}$ How much higher may depend on factors that vary from firm to firm. Other things being equal, the stock of a firm that issues a large number of shares will trade at lower prices than the stock of a firm that has issued fewer shares and consequently has not had to work so far down a downwardsloping demand curve. ${ }^{82}$ Among firms of equivalent size, the stock of firms whose names are familiar to the public should trade at higher prices than stocks that are relatively unknown to investors ${ }^{83}$ because high visibility expands the overall set of investors from which the subset of mostoptimistic investors is drawn. ${ }^{84}$ New companies whose futures are difficult

78. For example, if an initial offer of $\$ 10$ over market price induces the firm's current shareholders to sell $50 \%$ of their stock, raising the offer another $\$ 10$ may only convince them to part with another $25 \%$ of their shares. Similarly, raising the offer by still another $\$ 10$ may trigger only $10 \%$ in sales.

79. A "C"-shaped curve is consistent with the notion of "unit" elasticity, in which quantity demanded changes by the same percentage as price. This is because any fixed amount of stock-say, a thousand shares-comprises a larger and larger percentage of the remaining supply of outstanding stock as an acquirer succeeds in purchasing more and more shares. The acquirer must pay an accordingly higher premium for each additional thousand shares as he proceeds to "corner the market." See R. LIPSEY \& P. STEINER, supra note 27, at 95. There is evidence to suggest that average elasticity of investor demand for stocks approximates unit elasticity. See infra notes 105-08 and accompanying text.

80. The CAPM predicts that expected earnings should bear a linear relationship to market risk so that firms with identical market risk should trade at prices implying an identical rate of return and that when security prices are adjusted to take account of risk, all securities provide the same risk-free rate of return. Sep supra note 37.

81. Set supra notes $65-73$ and accompanying text.

82. There is evidence that the stocks of certain small firms in fact trade at lower risk-adjusted prices than the stocks of larger firms. That evidence is not inconsistent with the heterogenous-beliefs hypothesis, however, if smaller firms also tend to be relatively unknown to the bulk of investors, or tend to be newer firms about which less information is available. See infra note 112 (small firm effect).

83. Sie Miller, supra note 47 , at 1166 (increasing investor awareness of stock will increase its price). Empirical evidence supports the proposition that well known stocks trade at higher risk-adjusted prices than the stock of "neglected" firms. See infra notes 110-12 and accompanying text. The value of that empirical support is reduced to the extent that studies do not control for firm size. See supra note 82 and accompanying text.

84. Assume that two firms, A and B, each have three outstanding shares. There are ten potential investors, each of whom could purchase up to one share in each firm. Investor 1 thinks $A$ 's stock is worth $\$ 1$, Investor 2 thinks $\$ 2$, Investor 3 thinks $\$ 3$, and so forth up to Investor 10 , who believes A's stock is worth $\$ 10$. Only three of the investors $(1,5$ and 10$)$ have even heard of $B$. Investor 1 values $B$ 's stock at $\$ 1$; Investor 5 thinks $B$ is worth $\$ 5$; and Investor 10 thinks $B$ is worth $\$ 10$.

The mean and distribution of investor estimates of value are similar for firms $A$ and $B$. The market price for well-known A, however, will be $\$ 8$, while lesser-known B will trade at only $\$ 1$. That is 
to predict also should trade at higher prices than more-established companies of identical size with identical expected earnings and market risk. ${ }^{\mathbf{8 5}}$ When there is relatively little reliable information available to help investors gauge the worth of a firm, investors' estimates of value are more diverse: it is uncertainty that leads to differences of opinion, permitting both more optimistic, and more pessimistic, predictions. But because only the optimist determines price, the net result is that speculative, uncertain ventures trade at higher prices relative to risk than do well-established businesses. ${ }^{88}$

\section{Empirical Evidence of Stock Demand Elasticity}

The differing consequences for market behavior of a horizontal demand function and a downward-sloping demand function provide an opportunity to test which model more accurately describes modern securities markets. There is substantial evidence to support the claim that investor demand for stocks is, in fact, significantly downward-sloping.

More than a decade of empirical work has shown that large stock transactions-secondary distributions of blocks held by large shareholders, seasoned issuances of additional stock by corporations, and block

because the stock of each firm will be held by the three investors who have the most optimistic opinions of its value. While the third-most optimistic of A's ten potential investors values $A$ at $\$ 8$, the third-most optimistic of B's three potential investors values B only at $\$ 1$.

85. It is important in understanding this point to distinguish between risk (known or predictable variation in returns) and true uncertainty as to the future. See Miller, supra note 47, at 1154-55, 1166 (uncertainty causes investor opinions to be more divergent, so that stocks are likely to be overpriced relative to stocks with identical risk but less uncertainty). See generally F. KNIGHT, Risk, UNCERTAINTY AND PROFIT 197-263 (1921) (emphasizing distinction between "risk" and "uncertainty"). As a practical matter, new firms whose futures are uncertain may also tend to be firms with high degrees of market risk. If so, the heterogeneous beliefs hypothesis suggests that some classes of risky new firms will trade at higher prices and produce smaller returns than older, less risky companies.

Empirical evidence supports the claim that some classes of risky new firms do indeed trade at higher prices than less risky firms about which more information is available. See infra notes 110-17 and accompanying text. While that evidence is patently inconsistent with the CAPM, id., its value as support for the heterogeneous beliefs hypothesis is reduced to the extent that studies do not take account of the effect of firm size on stock prices. See supra note 82 and accompanying text.

86. Consider two firms, $A$ and $B$, each with three outstanding shares. There are ten potential investors, each of whom could purchase up to one share of each firm. Firm $A$ is an established company whose earnings and variation are relatively easy to predict. Investor 1 thinks A's stock is worth $\$ 11$, Investor 2 thinks $\$ 12$, Investor 3 thinks $\$ 13$, and so forth up to Investor 10 , who believes A's stock is worth $\$ 20$.

Firm $B$ has identical expected return and market risk as A. However, because firm B is a new company and little information is available, investor estimates of B's value are more diverse. Thus, Investor 1 thinks B's stock is worth $\$ 2$, Investor 2 thinks $\$ 5$, Investor $3 \$ 8$, and so on in increments of $\$ 3$ to Investor 8 , who believes $B$ is worth $\$ 23$, Investor 9 who thinks $\$ 26$, and Investor 10 , who believes B's stock is worth $\$ 29$.

The mean investor valuations for the stocks of A and B are identical- $\$ 15.50$ per share. Stock A, however, will trade at $\$ 18$ (the subjective valuation of the third most-optimistic of A's potential shareholders) while $B$ will trade at $\$ 23$ (the subjective valuation of the third-most optimistic of B's potential investors). As this example illustrates, so long as stocks are held by an optimistic minority of all potential investors, stocks about which investor opinion is more diverse will trade at higher prices relative to mean investor valuation than stocks about which investor opinion is more homogeneous. 
purchases and sales by index funds and other institutional investors-are accompanied by significant price changes. ${ }^{\text {" }}$ An example is Scholes' classic study of secondary distributions of outstanding stock held by large shareholders. ${ }^{88}$ Scholes found that secondary distributions averaging $2.2 \%$ of the firm's outstanding stock were associated with price declines of $2.2 \% .^{89} \mathrm{~A}$ price change of such magnitude indicates average demand elasticity of minus one for the stocks in Scholes' sample. ${ }^{90}$ At least on first inspection, this is strong evidence of a downward-sloping demand function. ${ }^{91}$ Other studies have similarly found substantial negative price reactions to the sale of large blocks of stock, including both secondary distributions by large shareholders and seasoned issuances by the corporation itself. ${ }^{22}$

Nevertheless, the extent to which these types of studies support the conclusion that demand is somewhat inelastic is hotly debated. The uncertainty arises from the possibility that the price declines associated with large sales reflect not price pressure, but investors' perceptions of the sale as a negative event which lowers their estimates of stock value. ${ }^{93}$ Investors may believe that large shareholders (in the case of secondary distributions) and corporate management (in the case of seasoned issues) have better information concerning the value of the firm's equity than the average shareholder. If so, the market may interpret a secondary distribution or

87. See Harris \& Gurel, Price and Volume Effects Associated with Changes in the SEP 500 List: New' Evidence for the Existence of Price Pressures, 41 J. Fin. 815, 816 (1986) (citing several studies which all found significant price drops following large sales); Shleifer, supra note 10, at 579, 588-89 (negative price reactions to large sales and positive reactions to purchases found in several empirical tests).

88. See Scholes, supra note 44.

89. Id. at 188 , Table 1 (mean distribution is $2.16 \%$ of firm's equity); id. at 193 (2.2\% average price decline).

90. Id. at 194. That finding is consistent with approximately "unit" demand elasticity. See infra notes $105-08$ and accompanying text.

91. Sep Scholes, supra note 44, at 193 ("initial evidence is in some respect consistent . . . with selling pressure"). Scholes concluded that new information and not price pressure caused the stock price declines he documented, because the size of the trade did not seem correlated with the degree of price shift observed and because the price change appeared to be permanent. Id. at 193-95. However, a permanent price change following a secondary distribution is consistent with a permanent shift in the aggregate demand function as a result of the exit of a large sharcholder from the market. Subsequent studies also have found that transaction size is, indeed, related to the degree of price change. See Asquith \& Mullins, supra note 9, at 65, 77-79 (size of equity offering significantly related to degree of price reduction); Kraus \& Stoll, Price Impacts of Block Trading on the New York Stock Exchange, 27 J. FIN. 569, 582-83 (1972) (same; noting that results differ from Scholes' and suggesting that there is therefore no way to distinguish between information and downward-sloping demand hypotheses). Moreover, the heterogeneous beliefs hypothesis predicts that demand elasticity and price pressure may vary from firm to firm. See supra notes 82-86 and accompanying text (factors that affect demand elasticity of different firms).

92. See, e.g., Asquith \& Mullins, supra note 9, at 85 (announcement of seasoned issue of additional equity by firm leads to average $2.7 \%$ price decrease); Kraus \& Stoll, supra note 91, at 575,577 (block sales accompanied by average $1.9 \%$ price decline, block purchases by $1.5 \%$ price increase); Mikkelson \& Partch, Stock Price Effects and Cosls of Secondary Distributions, $14 \mathrm{~J}$. Fin. Econ. $165,170,177-78$ (1985) (registered distributions averaging $8.1 \%$ of outstanding stock and unregistered distributions averaging $2.7 \%$ of outstanding stock associated with average price declines of $4.1 \%$ and $4.6 \%$, respectively).

93. See Asquith \& Mullins, supra note 9, at 87; Shleifer, supra note 10, at 579. 
seasoned issuance as a signal that the firm's stock is overpriced and readjust its estimate of stock value accordingly. The resulting price decline would not be attributable to downward-sloping demand, but to an efficient market's rapid incorporation of the information signaled by the fact of the sale. ${ }^{94}$

Because investors may extract information from sales by large shareholders or seasoned issuances by firms, most economists regard the results of large-transaction studies as inconclusive. ${ }^{95}$ Other tests of demand elasticity reduce the possibility of an information effect by focusing on the reaction of stock price to a firm's inclusion in the Standard \& Poor's 500 Index (S\&P 500). ${ }^{86}$ The stocks included in the S\&P 500 are chosen not for superior performance, but to reflect the market as a whole. Winners and losers are equally represented. The decision to include a new firm in the Index consequently is not based on any evaluation of a stock's worth but rather on its "representativeness" of an industry and the market. ${ }^{97}$

94. A third possibility is that large transactions affect prices because of "liquidity costs." Even if there are an infinite number of buyers who think the stock is worth its market price, they will not buy unless price is discounted slightly to compensate them for the transactions costs associated with changing their portfolios. See Harris \& Gurel, supra note 87, at 815-16, 828; Kraus \& Stoll, supra note 91 , at $570-71$.

Liquidity costs cannot explain price shifts in excess of the commissions and other transactions costs incurred in a particular trade. See Shleifer, supra note 10, at 587 (transactions costs cannot explain three percent price rise associated with index inclusion in S\&P 500 index when transactions costs of index funds that purchase S\&P 500 stocks amount to no more than one percent per trade). Morcover, such price changes should be temporary in nature. Kraus \& Stoll, supra note 91, at 570-71.

In contrast, price changes due to price pressure or new information should be permanent. An issue of new stock by the corporation expands supply, so that a new equilibrium price is set further down the demand curve. See supra note 75 (Figure 2). A large purchase or sale by an investor permanently shifts the demand curve inward or outward because the investor is adding or subtracting her demand to total investor demand for the stock. New information also permanently shifts the demand function by changing investor estimates of value (at least until more new information comes along).

In contradiction to the liquidity-cost hypothesis, most large-transaction studies have found permanent price changes. See Mikkelson \& Partch, supra note 92, at 189-90 (finding no evidence that price decline of stocks involved in secondary offering is subsequently reversed, implying no evidence of temporary liquidity effect for underwritten offerings); Scholes, supra note 44, at 194 (permanent price decrease associated with secondary distribution); Shleifer, supra note 10, at 583 (price changes associated with index inclusion appear to persist for at least one month). But see Harris \& Gurel, supra note 87, at 823, 828 (price changes completely reversed); Kraus \& Stoll, supra note 91, at 575-78 (partial rebound in prices).

95. See, e.g., Harris \& Gurel, supra note 87 , at 816 (transactions studies inconclusive because price change consistent with both downward-sloping demand and investors' extracting information from fact of sale); Shleifer, supra note 10, at 579 (same).

96. See, e.g., Harris \& Gurel, supra note 87; Lamoureux \& Wansley, Market Effects of Changes in the Standard \& Poor's 500 Index, 22 Fin. REv. 53 (1987); Shleifer, supra note 10 (indexinclusion tests).

97. See Harris \& Gurel, supra note 87 , at 817 (S\&P explicitly states judgments of value have no influence on listing decision; index inclusion should signal no positive or negative information); Shleifer, supra note 10 , at 580 (S\&P criteria for inclusion are size, industry classification, capitalization, trading volume, whether firm is emerging company or in emerging industry, and responsiveness of stock price to changes in industry affairs; all criteria are already public information, and none concerns future performance of firm). Firms are often delisted from the S\&P 500 following takeover, merger, or bankruptcy, or because they are no longer representative of their industry or the economy. Delisted firms are replaced with new, more representative listings. Harris \& Gurel, supra note 87, at 817. 
S\&P 500 listing therefore should not add any information relevant to stock performance beyond that already publicly available. ${ }^{98}$ But inclusion in the S\&P 500 does trigger large purchase orders on the part of "index funds" which seek to replicate the market's performance by carrying a portfolio of the stocks that make up the index. Those purchases may amount to three percent or more of the firm's outstanding equity. ${ }^{98}$ If demand for stock were perfectly elastic, such purchases would have no effect on price. ${ }^{100}$ However, index-inclusion studies have found that, on average, index listing is associated with stock price gains of three percent over the earlier market price. ${ }^{101}$ That result again suggests average demand elasticity of minus one.

It is possible that investors perceive inclusion in the $S \& P 500$ as a positive signal of firm stability. If so, inclusion alone might affect the market's valuation even in the absence of index fund purchases. While one cannot reject that supposition entirely, it seems (in the words of one commentator) "quite contrived." 102 This is particularly true in light of findings that index inclusion had no discernable effect on prices before index funds became common. ${ }^{103}$ Thus, the results of index-inclusion tests support downward-sloping demand over the information hypothesis. ${ }^{104}$

98. Harris \& Gurel, supra note 87, at 817; Lamoureux \& Wansley, supra note 96, at 54; Shleifer, supra note 10, at 579.

99. See Shleifer, supra note 10 , at 580 (institutional index funds may seek to purchase up to three percent of a firm's outstanding equity upon its inclusion in the $\mathrm{S} \& \mathrm{P} 500$ ); $c$. Harris \& Gurel, supra note 87 , at 817 (if all public and in-house index funds bought same proportion of shares in newly listed firms as their holdings of other index-listed companies, demand for those firms would increase $5.9 \%$ ). These figures may overstate the degree of buying by index funds. See Shleifer, supra note 10, at 585 (increase in trading volume associated with listing is substantially smaller than fraction of other S\&P firms held by index funds, perhaps because some funds delay their purchases in recognition of price pressure).

100. Shleifer, supra note 10 , at 580 .

101. Sep Lamoureux \& Wansley, supra note 96 (finding price increase with listing, a result consistent with price pressure); Shleifer, supra note 10, at 579, 582 (if demand downward-sloping, purchases by index funds raise equilibrium price by shifting demand function outward; finding three percent price increase associated with listing); see also Harris \& Gurel, supra note 87, at 821-22 (finding three percent price increase following index inclusion, but attributing this to reversible liquidity pressure). On liquidity costs, see supra note 94.

102. See Shleifer, supra note 10 , at $585-86$ (noting argument that because S\&P has reason to avoid unstable firms that might be delisted shortly after inclusion, listing may act as unintended signal of firm quality). Shleifer attempted to test the hypothesis that listing signaled S\&P's belief that the listed firm was stable by comparing the price effect of listing a firm whose bonds were already rated by S\&P with the price effects of listing unrated firms. Presumably, the latter would carry more new information cancerning S\&P's perceptions of firm stability. Shleifer interpreted his failure to find differences in price effects between the two samples as indication that S\&P listing does not signal new information concerning stock quality to the market. Shleifer, supra note 10, at 586-87.

103. Spe Harris \& Gurel, supra note 87 , at 821-22 (increasing price changes following index inclusion during period studied parallel increases in trading volume due to index fund buying, suggesting that data support downward-sloping demand rather than information hypothesis); Shleifer, supra note 10, at 582 (abnormal returns from stock inclusion cannot be found before index funds became common in 1976; after that, stock reactions have grown dramatically, parallel to growth of index funds).

104. Harris \& Gurel, supra note 87 , at $821-22$; Shleifer, supra note 10 , at 582 . The results of index-inclusion studies are even more significant when we consider that the studies test the price reaction of NYSE-listed firms for which investor demand should be relatively elastic. See infra note 
Interestingly, both the large-transaction and index-inclusion studies found average unit demand elasticity for the firms studied. ${ }^{105}$ In other words, a price increase of a particular percentage lowered the quantity demanded by investors by roughly the same percentage. Average unit elasticity also is consistent with evidence that as regulation has increased the average percentage of target shares purchased in tender offers from $32 \%$ to $73 \%$, average tender offer premiums have increased from $42 \%$ to $72 \%{ }^{108}$ Of course, such figures are only averages. The elasticity of investor demand may vary considerably from firm to firm and along an individual firm's demand function. ${ }^{107}$ Evidence of approximately unit elasticity is important not because it allows us to anticipate the price behavior of any individual stock, but because it supports the heterogeneous beliefs model's prediction of a convex demand function whose slope increases as it approaches the origin. ${ }^{108}$

A third form of evidence of downward-sloping demand can be found in certain "anomalous" classes of stocks that consistently underperform or outperform the market portfolio. According to the CAPM, all stocks should trade at prices implying identical expected risk-adjusted rates of return. ${ }^{109}$ However, studies have found that "neglected stocks" which are not closely followed by investors or analysts provide higher risk-adjusted returns than stocks that are more widely followed. ${ }^{110}$ While those findings conflict with the CAPM, they make sense under the downward-sloping demand hypothesis. ${ }^{111}$ Because increased investor awareness of a stock increases the universe of potential buyers from which the subset of mostoptimistic buyers is drawn, better-known firms should trade at higher

119.

105. See Scholes, supra note 44, at 193-94 (distributions averaging two percent associated with two percent decline in price); supra notes 98-101 and accompanying text (stock inclusion triggering three percent acquisitions associated with three percent increase in price). Average demand may be more inelastic than these studies indicate. See infra note 119 (studies test stock of firms about which much is known, and demand for these firms is likely to be more elastic).

106. See Jarrell \& Bradley, supra note 40, at 373, 389 (Table 1) (noting that Williams Act regulation increased average tender offer premium from $32 \%$ to $53 \%$, and widespread passage of state anti-takeover statutes has increased average premium in those states to $73 \%$; also noting that typical percentage of shares purchased in offer increased from $42 \%$ to $61 \%$ to $72 \%$ following these events).

107. For example, investor demand for the stock of relatively unknown firms about which investors disagree strongly should be more inelastic than demand for well-known firms. See supra notes 85-86 and accompanying text (arguing that investor opinions are more diverse for firms about which little is known, so that demand is more inelastic and market price set by opinions is relatively high). Great variance in takeover premiums also is indirect evidence that demand elasticity varies from firm to firm. See W.T. Grimm \& Co., Mergerstat Review 1986, at 89 (1987) (table of distribution of premiums from 1975-86).

108. See supra notes 75-79 and accompanying text (predicting convex demand function).

109. See supra notes 35-37 and accompanying text.

110. Miller, supra note 68, at 9 (citing evidence of higher returns on neglected stocks); Wang, supra note 2, at $357 \mathrm{n} .39$ (citing evidence that securities neglected by most analysts and institutional investors achieve superior risk-adjusted returns).

111. See Miller, supra note 47, at 1164-66. 
prices implying lower risk-adjusted returns than more anonymous companies. ${ }^{112}$

Studies that indicate certain classes of stock with very high market risk actually bring smaller returns than less risky classes provide even more powerful evidence to support the downward-sloping demand hypothesis. ${ }^{113}$ Such findings are impossible to reconcile with the CAPM's prediction that because investors demand a premium for accepting nondiversifiable risk, risk and return should be positively correlated. ${ }^{114}$ Assuming, however, that the riskiest stocks are also those whose futures are most uncertain, a negative risk premium again can be explained under the heterogeneous beliefs pricing model. ${ }^{115}$ Ignorance encourages greater divergence of investor opinion, allowing not just optimism, but wild optimism. Because stock prices are set by an optimistic subset of all possible investors, risky stocks should trade at prices that are inflated relative to less risky securities. ${ }^{116} \mathrm{~A}$ similar phenomenon may explain why new issues tend to underperform the rest of the market in their first five years, when there is greater uncertainty about the future of the firm and investor estimates of value are more diverse. ${ }^{117}$

In sum, the empirical evidence provides strong support for the downward-sloping demand hypothesis. ${ }^{118}$ Studies of the price effects of large

112. The "small firm effect" also may be evidence of this. Studies have found that the stocks of small firms tend to have greater risk-adjusted returns than large companies. See Coffee, Market Failure and the Ecanomic Case for a Mandatory Disclosure Sistem, 70 VA. L. REv. 717, 750 n.94 (1984) (recurrent finding that small firms earn abnormally high risk-adjusted returns); Wang, supra note 2, at 353-54 (same). If small firms are also "neglected" firms unknown to the bulk of investors, the smaller pool of potential investors for such firms would make them tend to be underpriced relative to better-known companies. See supra notes 83-84 and accompanying text. The value of the small firm effect as evidence supporting the heterogeneous beliefs hypothesis is eroded, however, by the possibility that small firms should be overpriced relative to the stock of larger companies if demand is downward sloping, because larger firms must work their way further down the demand function to sell larger amounts of stock. See supra note 82 . Because the factors of investor ignorance and firm size work against each other, the small firm effect cannot be regarded as conclusive evidence either for or against downward-sloping demand.

113. Miller, supra note 47 , at 1155 .

114. Holcombe \& Saba, supra note 56, at 359-60; Miller, supra note 47, at 1155.

115. "Risk" refers to the distribution of stock returns. "Uncertainty" refers to an inability to predict outcomes. See supra note 85 . Stocks that are quite risky may nevertheless be predictable; tossing a coin is "risky" in that there is great variation in results, but the probability distribution (half heads, half tails) is entirely predictable and certain. See Miller, supra note 47, at 1154-55 (risk versus uncertainty). Risk and uncertainty often go together, however. New or speculative ventures often have a high degree of market risk as well, and it seems reasonable to presume that firms whose stocks carry a high degree of market risk often have relatively uncertain futures. Id. at 1154 (risk and uncertainty often go together).

116. Sep supra notes 66-70 and accompanying text (short sales restrictions ensure optimists determine price); notes 85-86 and accompanying text (uncertainty allows greater overpricing).

117. In the weeks and months immediately following issuance, new issues tend to outperform the market, probably because of market imperfections that create incentives for underwriters to "underprice" such offerings. See Stout, supra note 3, at 658-63 (discussing underpricing). Following this initial positive performance, however, new issues tend to lag behind the market, a finding consistent with downward-sloping demand. Miller, supra note 47, at 1156.

118. If any additional proof of downward-sloping demand is needed, it can be found in the practice of selling securities by auction. See R. Brealey \& S. MYers, supra note 9, at 773 (describing auctions of government bonds); Banoff, Regulatory Subsidies, Efficient Markets, and Shelf Registra- 
transactions and S\&P 500 inclusion find price changes that are consistent with roughly unit average demand elasticity. ${ }^{119}$ At least in the case of the index-inclusion studies, those changes are unlikely to be the result of new information. Findings that the stocks of very risky firms and "neglected" firms trade at higher risk-adjusted prices than more stable and wellknown firms, while contrary to the predictions of the CAPM, are consistent with downward-sloping demand as well.

The downward-sloping demand hypothesis has intuitive appeal. It is consistent with both the empirical evidence and the beliefs of those who actually transact business in securities markets. And, as will be seen in the following Section, it provides an explanation for several forms of market "misbehavior" inconsistent with perfectly elastic investor demand. The downward-sloping demand hypothesis is not only a viable alternative to the CAPM's horizontal-demand hypothesis; it is a superior alternative.

\section{Demand Elasticity and the Regulation of Corporations and Securities Markets}

Because state and Federal regulation of corporations and securities markets predates the development of the CAPM's theory of perfectly elastic demand, it is not surprising that many traditional legal doctrines assume that stock demand is downward-sloping. A belief that large transactions exert price pressure is apparent, for instance, in the Federal prohibition against "manipulative" transactions ${ }^{\mathbf{1 2 0}}$ and in SEC regulations limiting underwriters' "stabilizing" purchases during the distribution of an equity issue. ${ }^{121}$ Other time-honored doctrines presume that the market price for a stock may depart from its intrinsic value. ${ }^{122}$ That view is more

tion: An Analysis of Rule 415, 70 VA. L. REv. 135, 147 (1984) (describing "dutch auction" in which private securities are sold to different buyers at varying prices). Sellers who use the auction process find that incremental decreases in price produce incremental increases in demand. Id. Such market behavior is patently inconsistent with perfectly elastic demand and homogeneous beliefs.

119. These findings of substantial inelasticity are more persuasive in light of the fact that, for the most part, researchers testing stock elasticity have compiled their data from the price behavior of exchange-listed firms. See, e.g., Asquith \& Mullins, supra note 9, at 66 (sample drawn from ASEand NYSE-listed firms, includes only well-established and heavily traded stocks); Kraus \& Stoll, supra note 91, at 571 (sample drawn from NYSE-listed firms); Shleifer, supra note 10, at 581 (index-inclusion sample drawn from exchange-listed firms selected for S\&P 500). Because more information is available about such firms, investors' estimates of value should be less diverse than in the case of smaller firms about which less is known. The more homogeneous investor opinion, the more elastic demand is likely to be. See supra notes 85-86 and accompanying text.

120. Federal anti-manipulation law predates the development of the CAPM and appears to assume that large transactions affect prices. See Securities Exchange Act of 1934, $\$ 9,15$ U.S.C. $\$ 78 \mathrm{i}$ (1988) (anti-manipulation provision prohibiting transactions designed to influence prices); cf. Alabama Farm Bureau Mut. Casualty Co. v. American Fidelity Life Ins. Co., 606 F.2d 602, 611 (5th Gir. 1979) (purchases of large amounts of stock necessarily drive prices upward).

121. 17 C.F.R. $\$ \S 240.10 \mathrm{~b}-6,240.10 \mathrm{~b}-7$ (1988); see also Hess \& Frost, Tests for Price Efferts of New" Issues of Seasoned Securities, 36 J. Fin. 11, 13-14 (1982) (describing and criticizing "SEC view" that stabilizing purchases artificially drive prices upward as inconsistent with perfect substitutability and perfectly elastic demand).

122. Examples include the appraisal remedy, which allows shareholders to claim the "true" value 
consistent with heterogeneous beliefs and a downward-sloping demand function than with the CAPM's tenet that stock market prices are the only rational measures of value. ${ }^{123}$

With the increasing dominance of the CAPM, however, growing numbers of commentators have come to presume that the demand function for stock is horizontal. ${ }^{124}$ Traditional legal theories have begun to give way to new doctrines premised on perfectly elastic investor demand. This section considers three areas in which the perfect elasticity hypothesis has had great influence: the ongoing debate over the social value and appropriate regulation of corporate takeovers, the dispute over the economic benefits and harms of insider trading, and the problem of valuing the corporate entity in appraisal and similar contexts.

\section{A. Corporate Takeovers}

Contemporary discussions of takeover policy generally begin with the riddle of takeover premiums. ${ }^{125}$ On average, a target company's shareholders receive fifty percent more for their shares in a tender offer or merger than the prevailing market price for their stock before the bid was announced. ${ }^{128}$ In an efficient market, however, a security should trade at a price equivalent to the present value of its expected returns, discounted for nondiversifiable beta risk. The shares of a potential takeover target are worth exactly what they are trading for: no rational buyer would offer to pay more. ${ }^{127}$

of their shares, see infra Section II.C., and deference to claims by target management that a premium takeover price is "inadequate." See infra notes 172-84 and accompanying text.

123. Sie Electronic Specialty Co. v. International Controls Corp., 409 F.2d 937, 947-48 (2d Cir. 1969) (forcing firm to divest large number of shares acquired in tender offer "probably would involve certain and huge loss" when large sale depressed prices); Scholes, supra note 44, at 180 (courts in antitrust cases assume that selling large block of stock depresses prices); Note, supra note 44, at 1046 (tax valuation doctrine that large blocks of stock have average value less than market, because their sale would depress stack prices).

124. Set authorities cited supra note 39; see also Baysinger \& Butler, supra note 54, at 1283 n.96 (neoclassical financial theory assumes perfectly elastic demand for stocks); Booth, supra note 39, at 638 n.28 (outside of extraordinary transaction like buyout, efficient market theory suggests that investors' demand for stock in normal trading is not downward-sloping); Fisher \& Lande, supra note 45, at $1618 \mathrm{n} .144$ (CAPM suggests all stocks are perfect substitutes, implying no need to pay premium to acquire control); Garten, Insider Trading in the Corporate Interest, 1987 WIS. L. REv. 573, 627 n.240 (theoretically, demand for stock is perfectly elastic, and insider trading does not move price); Gilson, The Case Against Shark Repellent Amendments: Structural Limitations on the Enabling Concept, 34 ST.AN. L. REv. 775, $796 \mathrm{n} .81$ (1982) (because of perfect substitutability, large transactions should not change prices; suggesting takeover bid drives up market price because bid brings new information to market).

125. Coffee, supra note 5 , at 1162.

126. Sie authorities cited supra note 1; Bradley, Interfirm Tender Offers and the Market for Corporate Control, 53 J. Bus. 345, 345 (1980) (49\% average premium in tender offer). While the average premium is $50 \%$, there is much variation. Premiums of $100 \%$ or more are not unusual. See W.T. GRIMM \& Co., supra note 107, at 89 (table of distribution of premiums from 1975-1986).

127. See Easterbrook \& Fischel, Corporate Control, supra note 6, at 705 (irrational for bidder to pay premium unless he anticipates increase in value); Schwartz, The Fairness of Tender Offer Prices in Ulilitarian Theory, 17 J. LEGAL STUD. 165, 189 (1988) (market theory suggests bidders who offer premium must expect to increase target's earnings). 
Yet bidders do pay premiums, and large ones. ${ }^{128}$ Their willingness to do so has played a crucial role in the debate over the appropriate scope and nature of takeover regulation. Because the stock of a firm that makes a premium bid generally neither rises nor declines, ${ }^{129}$ many scholars and policymakers believe that takeover premiums prove that takeovers are "value-creating." Bidders can pay greater-than-market prices without suffering a decline in the price of their own shares because both the bidder and the stock market believe that a merger between the bidder and the target will increase the aggregate earnings of the two firms by a commensurate amount. ${ }^{130}$ On that theory, takeover premiums are widely viewed as strong evidence that takeovers produce social gains by directing the flow of corporate assets to those who will maximize their value. ${ }^{181}$

The source of those perceived efficiency gains is unclear. Some argue that takeovers increase earnings by exploiting potential economies of scale, economies of scope, or other "synergies" between the merging firms. ${ }^{132}$

128. This behavior is so inconsistent with the CAPM that some commentators argue that takeover premiums are evidence that the market irrationally undervalues firms. See Coffee, supra note 5, at 1170-71 ("exploitation" thesis where bidders buy assets by purchasing underpriced stock); Kraakman, supra note 1, at 898-901 (share prices may discount real value of underlying assets if market price is distorted); Wang, supra note 2, at 398-99 (argument that takeover premiums reflect irrational market pricing stock at less than intrinsic value). A variant of this theory is the argument that target managements run firms so poorly that takeover bidders can profit by simply buying the target's stock at prices reflecting low earnings and then "looting" the firm by selling off assets. See Kraakman, supra note 1, at 897-98. Both forms of misvaluation theory predict-contrary to the findings of bidder share price studies-that acquiring firms should reap substantial profits from takeovers. See infra notes $144-46$ and accompanying text; see also Black, supra note 1, at 607-08 (criticizing misvaluation theories).

129. While some studies have shown slight gains in bidder share price, others have shown slight losses. See Black, supra note 1, at 602-05 (summarizing studies). The consensus of the financial community seems to be that bidder share price is not substantially affected by takeovers. Fisher \& Lande, supra note 45, at 1615; see also Black, supra note 1, at 598 (on average, no offsetting drop in bidder's share price); Kraakman, supra note 1, at 894 \& $n .8$ (acquirers' shareholders "do not seem to suffer losses, and may also register gains").

130. See Black, supra note 1, at 598-99 (financial economists believe premiums reflect efficiency gains); Kraakman, supra note 1, at 892 (if prices reflect true value, acquirers would never pay $50 \%$ premium without expecting target to earn at least $50 \%$ more than at present); Easterbrook \& Fischel, Corporate Control, supra note 6 , at 705 (bidders would not pay premiums unless they could run targets more efficiently); Wolfson, A Critique of the Secumties and Exchange Commission, 30 EMORY L.J. 119, 131 (1981) (takeover bidders pay premiums in expectation of their superior management increasing value of target's stock to level in excess of premium).

Tests of bidder share price measure the wisdom of acquisitions in the eyes of bidders' shareholders. Because there is no reason to believe that an acquisition triggers unusual trading in the stock of the bidding firm, changes in bidder price following an acquisition announcement can be attributed to the markets' adjusting its estimate of firm value in light of the new information. If the bidder's shareholders believe the acquisition is a good one, share price should rise; if the shareholders view the deal unfavorably, price should decline.

131. See Baysinger \& Butler, supra note 54, at 1257 ("widely believed" that takeovers allocate corporate resources to their highest valued use); Black, supra note 1, at 599 (financial economists' view that takeovers are "a valuable force in the U.S. economy"); see also Edgar v. MITE, 457 U.S. 624, 643 (1982) (takeovers can improve efficiency); Bebchuk, The Case for Facilitating Competing Tender Offers, 95 HaRv. L. REv. 1028, 1033 (1982) (assumes that takeovers increase social welfare); Easterbrook \& Fischel, Corporate Control, supra note 6, at 703-15 ("strong presumption" that takeovers move assets to higher valued uses); Gilson, supra note 15, at 841-42 (takeovers benefit society by ensuring more efficient use of resources).

132. Sep Black, supra note 1, at 608-11 (describing orthodox synergy theory); Coffee, supra note 
Others suggest that takeovers increase profits because they replace incompetent or dishonest management with more efficient leadership. ${ }^{133}$ Whatever the source of gains, corporate takeovers seem beneficial when viewed in the flattering light of value-creating theories. A fifty percent increase in the profits of target firms not only enriches the participants in such transactions, it enriches society as a whole. ${ }^{134}$ Proponents of valuecreating theories accordingly view takeovers as a vital source of efficiency gains that should be nurtured and protected and argue that policymakers should curb defensive tactics that make takeovers more difficult. ${ }^{135}$

Other commentators offer a far less complimentary explanation for takeover premiums. According to the "bidder overpayment" theory, takeover premiums are evidence that bidding firms simply pay too much for their targets. ${ }^{136}$ This occurs because entrenched management chooses to use retained earnings to expand its empire through overpriced, wasteful acquisitions, rather than pass those earnings on to shareholders in the form of dividends. ${ }^{137}$ The bidder-overpayment theory implies that most takeovers do not produce real social gains, but instead may be wasteful transactions that impose excessive transactions costs and disruption to the target firm's employees and community without any offsetting social benefit. ${ }^{138}$ That view implies that lawmakers should impose constraints on such wasteful behavior. ${ }^{139}$

5, at 1166-67 (synergy hypothesis); Kraakman, supra note 1, at 894 \& n.9 (synergy "most strongly supported" among traditional accounts of gains).

133. Sep Coffee, supra note 5, at 1163-66 (disciplinary hypothesis); Easterbrook \& Fischel, Corporate Control, supra note 6 , at 705 (presumption that takeovers reduce management inefficiency); Gilson, supra note 15, at 841-42 (takeovers replace inefficient management).

134. Takeover gains also have been attributed to tax reductions through increased leverage and release of "trapped equity," and to increased ability to extract monopoly profits. Such explanations imply that takeovers may bring gains to the participants without benefiting society as a whole because the participants' gains are offset by some other parties' losses. See Bebchuk, supra note 131, at 1031-32 (monopoly benefits and tax savings produce no sacial gains). But see Black, supra note 1, at 611-12 (wealth transfer explains "at most a fraction" of gains).

135. See sources cited supra note 15 , infra note 181 .

136. See Black, supra note 1, at 599 (advancing overpayment hypothesis as partial explanation); Coffec, supra note 5, at 1157, 1167-69 ("empire-building" hypothesis holds that bidders overpay for targets, resulting in wealth transfers rather than efficiency improvements); Easterbrook \& Fischel, Proper Role, supra note 6, at $1185-86$ (self-aggrandizing management may squander acquirer's money by paying too much).

137. Black, supra note 1 , at $599,627-28$

138. Takeovers are often condemned as imposing uncompensated costs on third parties such as the target's employees, customers and community. See S. REP. No. 265, 100th Cong., 1st Sess. 14 (1987) (takeovers may harm employees and community); Gilson, supra note 15, at 862-63 (noting management's and commentators' concern for third parties affected by takeovers); Johnson \& Millon, Missing the Point About State Takeoter Statutes, 87 Mich. L. REv. 846, 848 (1989) (state legislatures perceive takeovers as destructive to non-shareholder constituencies like employees, suppliers and customers).

Value-creating acquisitions also involve transactions costs and disruption to third parties. Such losses, however, are more defensible if takeovers produce real social gains.

139. See Coffee, supra note 5, at 1173, 1224-26 (because public policy "should seek to discourage mere wealth transfers," discouraging empire-building acquisitions is desirable; suggesting that overpayment may even allow inefficient transactions in which poorly performing bidders buy good targets to improve overall performance). But see Black, supra note 1, at 647,653 (noting that since overpay- 
The social utility of corporate takeovers is an important issue if only for the sheer amount of money involved. Acquiring firms spent an estimated $\$ 226$ billion for corporate acquisitions in $1988 .{ }^{140}$ If average premiums of fifty percent represent real efficiency gains, takeovers created approximately $\$ 75$ billion in new wealth in 1988 alone. ${ }^{141}$ The perceived value of acquisitions also can be crucial to the decisions of courts and legislatures called upon to regulate the activities of bidders and their targets. ${ }^{142}$ Given the enormous sums of money involved and the importance of the issues, one would expect that a decade of close analysis might have produced some sort of consensus on the question of whether takeovers are productive or destructive. But the debate rages on. In large part, this is because neither value-creating theories nor the overpayment thesis provides an entirely persuasive account of acquisition behavior.

Although stock price studies indicate that corporate acquisitions increase the value of target firms by fifty percent, accounting evidence on the success of corporate acquisitions is far less conclusive. Accounting studies have failed to produce evidence that takeover targets become either more or less profitable under new management. ${ }^{143}$ Sows' ears have stubbornly remained sows' ears, and silk purses, silk purses.

Another puzzle is why takeover gains appear to be enjoyed almost exclusively by the target's shareholders. If premiums reflect the bidding firm's ability to improve the target's earnings, there seems to be no reason

ment is merely wealth transfer from bidder to target shareholders, and bidder might misinvest money anyway, overpayment may not impose social loss; suggesting that market constraints on overpayment may be desirable).

140. Demand for Public Companies, 24 Mergers \& AcQuisirions, July-Aug. 1989, at 12.

141. Cf. Black \& Grundfest, Shareholder Gains From Takeovers and Restructurings Beturen 1981 and 1986: \$162 Billion Is a Lot of Money, 1 Continental Bank J. ApPlied Corp. Fin. 5 (1988) (premiums indicate that between 1981 and 1986 takeovers increased shareholder wealth by at least $\$ 162$ billion).

142. In recent years state courts in general and the Delaware court in particular have produced a number of landmark cases in the takeover area. See, e.g., Paramount Communications, Inc. v. Time, Inc., Fed. Sec. L. Rep. (CCH) I] 94,514 (Del. Ch. July 14, 1989), affd, 565 A.2d 280 (Del. July 24, 1989) (discretion of directors to reject premium bid); Revlon v. MacAndrews \& Forbes Holdings, Inc., 506 A.2d 173 (Del. July 24, 1986) (duty of directors to seek highest price in auction context); Smith v. Van Gorkom, 488 A.2d 858, 872 (Del. 1985) (duty of care in responding to bid). State legislatures also have entered the fray with a host of "anti-takeover" statutes passed in the wake of the Supreme Court's decision in CTS Corp. v. Dynamics Corp., 481 U.S. 69 (1987) (upholding constitutionality of Indiana statute). See Macey, State Anti-Takeover Legislation and the National Economy, 1988 Wis. L. REv. 467, 468 n.4 (describing "current spate" of anti-takeover legislation following CTS decision). The U.S. Congress has also considered legislation in the area. See, e.g., S. 1323, 100th Cong., 1st Sess. 61-62 (1987); S. ReP. No. 265, 100th Cong., 1st Sess. (1987) (proposed legislation extending Williams Act requirements to any purchase of more than $25 \%$ of a target's stock, whether by tender offer or otherwise). See also Staff of the JoInt CommitTeE ON TAXation, 101st Cong., 2d Sess., Federal Income Tax Aspects of Corporate Financial Structures 58 (Comm. Print 1989) (source of efficiency gains implied by premiums is important in evaluating desirability of tax legislation that affects buyouts).

143. See D. Ravenscraft \& F. Scherer, Mergers, Sell-offs, and Economic Efficiency 121-22, 212 (1987) (acquiring firms do not have great success in running target companies more profitably); Black, supra note 1, at 598-99, 605-06 (reviewing accounting studies; concluding they fail to show improvement in target performance); Fisher \& Lande, supra note 45, at 1614 (little to. learn from accounting studies). 
why bidders should voluntarily pass those gains on to target shareholders. ${ }^{144}$ Alternatively, if takeover "gains" are really bidder overpayment, it is natural that only target shareholders benefit from acquisitions. But that raises the question of why an efficient market would not penalize bidders for such profligate behavior. ${ }^{145}$ Overpriced bids should trigger declines in the bidding firm's stock; yet, acquiring firms' shares appear to be largely unaffected by acquisitions. ${ }^{146}$

Finally, and perhaps most significantly, neither value-creating nor overpayment theories satisfactorily explain the sheer magnitude of current premiums. ${ }^{147}$ That bidders expect to run target firms fifty percent more efficiently, or that they are willing to overpay to that extent, seems equally improbable. ${ }^{148}$ And if takeover premiums reflected either real productivity gains or gross overpayment, surely this would be reflected in the accounting data or bidders' share prices. ${ }^{149}$

Conventional theories fail to explain takeover premiums persuasively. Undoubtedly, some takeovers are motivated by perceived opportunities for efficiency gains, while others are wasteful empire-building transactions. But the persistent and striking phenomenon of fifty percent average premiums has proven intractable for the CAPM under its assumption of perfectly elastic demand. ${ }^{150}$

144. If bidders can select from among a number of potential targets, target shareholders should not exhibit so much bargaining power that they extract all the gains to be had from an acquisition. Sic Black, supra note 1, at 603 (usual explanation for target shareholder capture of gains is that bidder faces competition from other suitors; noting problems with this explanation); see also Carney, supra note 26, at 371 (arguing that rational bidders will not compete vigorously with each other).

145. Ser Easterbrook \& Fischel, Proper Role, supra note 6, at 1185-88 (criticizing overpayment theory on grounds that bidder's price should decline and that labor and product markets should discipline such wastefulness).

146. Sir authorities cited supra note 1. Professor Black has argued that bidders' shares do not decline because the market has already discounted them in anticipation of wasteful acquisitions. See Black, supra note 1 , at 599 . This argument supposes that shareholders in acquiring firms can predict a wasteful acquisition so accurately that the actual acquisition announcement does not bring any new intormation that changes their subjective estimates of stock value. Even if shareholders tend to discount their shares' value out of a general suspicion that management may make a wasteful acquisition, one would expect those shares to decline still further when the shareholders' fears are realized. Also, if a bidder can choose from among a reasonable number of potential targets, there seems no reason for it to choose overpriced rather than reasonably priced targets. Cf. Black, supra note 1 , at 629-32 (even overpaying bidder has no incentive to pay more than market-clearing price; product, capital, labor, and corporate control markets place constraints on overpayment; suggesting that supply of targets is limited by management resistance).

147. This observation is also troubling for the theory that takeover premiums reflect market misvaluation. Sie supra note 128 . Market discounts of $50 \%$ seem unlikely.

148. See Easterbrook \& Fischel, Proper Role, supra note 6, at 1185 (questioning how bidders could overpay by amount of premium without being disciplined by product and labor markets); see alwo Colfee, sufpra note 5, at 1201 (disciplinary hypothesis implies that target management has more than halved the value of the firm); Gilson, supra note 15, at 852 (asserting that target firms underperform to extent of $50 \%$ of potential value).

149. So Black, supra note 1, at 599 (accounting studies should show clear evidence of $50 \%$ efficiency gain).

150. Occasionally commentators note that takeover bidders may face an upward-sloping supply curse. Sit', 6. . B. Booth, supra note 39, at 638; Carney, supra note 26, at 354; Coffee, supra note 5, at $1183-85$; Gilson, supra note 124 , at 796 \& n.81. Some assert that stock demand is normally perfectly elastic and that an upward-sloping curve in the context of a takeover bid is an artifact of target 
In contrast, takeover premiums can be readily explained by a downward-sloping demand function. Under the heterogeneous beliefs hypothesis, the price of a single share on the market can no longer be viewed as an accurate reflection of the market value of each and every one of the firm's outstanding shares. Instead, the market value of the firm (as measured by the total price its current owners would require to willingly part with their interests) is the sum of the varying subjective valuations that each of its shareholders attaches to his or her holdings. ${ }^{151}$ Those estimates increase as the bidder works up a sloping demand function. ${ }^{132}$

Consider the hypothetical case of a bidder who wants to purchase, as cheaply as possible, all the outstanding stock of a target firm. ${ }^{153}$ The bidder keeps its takeover plans secret and makes its purchases on the open market. If the current market price for the target's stock is $\$ 20$, the bidder should be able to buy a modest number of shares at that price. But the number of shareholders who value their shares at $\$ 20$ (and hence the number who will be willing to part with their shares at that price) is limited. To induce more-optimistic shareholders to sell, the bidder must offer first $\$ 21$ a share, then $\$ 22$, then $\$ 23$, and so forth. Thus the bidder who works his way up a convex demand function composed of shareholders with ever-increasing subjective reservation prices must pay larger and larger premiums over market price. $^{154}$ To obtain the last outstanding share from the remaining, most-optimistic shareholder, the bidder may have to offer $\$ 40$ or more. The last shareholder demands that premium

shareholders' reaction to news of the bidder's interest. In other words, even though the target's shareholders do not believe that the intrinsic value of their shares has changed, they strategically revise their reservation prices upward in response to a premium bid to extract a higher price from the bidder. See infra note 155; Booth, supra note 39 , at $637-38$ \& n.28 (upward-sloping stock supply curve in management buyout consistent with efficient market theory because such extraordinary transactions focus shareholder attention on negotiations with particular buyer who values firm more highly); Gilson, supra note 124 , at 796 n.81 (upward-sloping supply consistent with perfect substitutability because tender offer carries new information which shifts price). Others appear to acknowledge the possibility of generally inelastic demand. See Booth, The Problem II'th Federal Tender Offer Law, 77 CaLIF. L. REv. 707, 716 \& n.32 (1989) (assuming downward-sloping demand curve); Carney, supra note 26, at 357 (while supply curve for stock is perfectly elastic over much of its length, it is not over entire length); Coffee, supra note 5, at 1183-85 (suggesting generally upward-sloping curve); $f$. Schwartz, supra note 127, at 188-90 (noting but ultimately discounting view that some investors may value stock substantially above market or even premium offer). However, the literature largely overlooks the inference that if bidders face an upward-sloping supply curve, premiums evidence nothing more than price pressure. See authorities cited supra. But see Levmore, A Primer on the Sale of Corporate Control (Book Review), 65 TEx. L. REv. 1961 (1987) (briefly noting that acquirers may pay premiums because "inframarginal" shares of corporation are highly valued by shareholders).

151. See supra note 75 (in Figure 2, total market value is represented by the shaded area under the demand function D1-D1).

152. Since most acquisitions require that the bidder either purchase $50 \%$ of outstanding shares or persuade $50 \%$ of current shareholders to vote favorably, average takeover premiums of $50 \%$ are consistent with average unit elasticity. See infra notes $169-70$ and accompanying text (50\% approval); supra notes 105-06 and accompanying text (unit elasticity).

153. As a practical matter, most large acquisitions are made at a uniform price. See infra notes 157-61 and accompanying text.

154. See supra note 75 (Figure 2). 
not in a strategic attempt to "hold out" for extra payment, but because $\$ 40$ is her honest, if perhaps highly optimistic, assessment of the intrinsic value of her shares. ${ }^{105}$

Once we assume inelastic demand, the behavior of acquisition markets begins to make sense. Bidders offer substantial premiums over market price to induce those shareholders who value their stock more highly than the market to sell. The "premium" is not really a premium at all. It is simply the price necessary to persuade more-optimistic shareholders with higher reservation prices to sell the shares the bidder must purchase to gain control. ${ }^{166}$

Of course, the scenario described above-in which a bidder obtains ownership of a target through a series of transactions with individual shareholders at varying prices-is unrealistic. A complete acquisition through a series of individually negotiated transactions at different prices poses almost insurmountable practical ${ }^{157}$ and regulatory ${ }^{158}$ problems for

155. If a bidder were to attempt to purchase $100 \%$ control through a series of individually negotiated transactions, and if the target's shareholders were to learn of this, opportunities for strategic behavior would arise. In practice, however, the legal rule permitting $50 \%$ shareholder approval of mergers severely limits individual opportunities for strategic behavior. See infra notes 273-74 and accompanying text (rule of unanimity).

Announcement of the bidder's intentions may also cause the target's shareholders to raise their estimates of share value and their subjective reservation prices. Carney, supra note 26, at 347 . There is some evidence that this occurs. See Gilson, supra note 15, at 856-57, 866-67 (studies indicate that after takeover bid fails, target's shares remain above pre-bid prices; some claim this is result of shareholders' adjusting their reservation prices, or of target management's release of favorable information to discourage bid). However, this phenomenon cannot explain takeover premiums. No rational shareholder would adjust his reservation price above the level of the bid. It is the bid which causes the shift in reservation price, not vice versa. The net effect is that announcing a bid may shift outwards that portion of the demand function which lies below the offering price. A similar shift occurs when an insider trades on non-public news of a premium bid. See infra notes 233-34 and accompanying text (Figure 4).

156. Cf. Toms, Compensating Shareholders Frozen Out in Two-Step Mergers, 78 Colum. L. Pev. 548, 557 (1978) (success of tender offer will "depend on the demand of the last necessary shareholder").

157. The necessity of buying from all shareholders in voluntary transactions creates the risk that one will veto the transaction or hold out for unreasonable payment. See infra notes 273-74 and accompanying text. Acquisitions of five percent or more also trigger the Williams Act's disclosure requirements, requiring bidders to reveal publicly the amount and intent of their purchases. See Securities Exchange Act of 1934, $\S 13($ d), 15 U.S.C. $\$ 78 \mathrm{~m}$ (d) (1988). Disclosure creates the danger of competing bids, and that risk increases the longer an offer is outstanding. This makes a series of tender offers at varying prices especially unattractive, as SEC rules promulgated under the Williams Act require each tender offer to remain open at least 20 days. 17 C.F.R. $\$ 240.14$ e-1(a) (1989). Privately negotiated purchases avoid these problems to some extent but are an impracticable means of acquiring control unless stock ownership is unusually concentrated.

158. Attempting a takeover through a series of purchases carries the potential for liability for "short-swing" profits should the takeover bid fail. Under section 16 of the Securities Exchange Act of $1934,10 \%$ shareholders must disgorge to the corporation all profits made from trading in the stock of their firms within a six-month period. 15 U.S.C. $\$ 78 \mathrm{p}$ (1988). Because profits are measured by matching the lowest purchase prices against the highest sale prices within a six-month period, $R$. Clark, Corporate Law 299-300 (1986), a would-be acquirer who buys target stock at increasingly high prices and then sells within six months at decreasing prices would face substantial liability. A second regulatory problem arises because "tender offer" is not defined in the Williams Act. A series of private purchases or a "street sweep" during or after a tender offer runs the risk of being held a tender offer. See id. at 559-64 (problem of defining tender offer). If private purchases are held to be a "tender offer," the bidder is subject to the Williams Act's requirement that all shareholders must 
bidders. Although a bidder may begin a takeover attempt by acquiring a modest "toehold" in the target's stock through open-market or private purchases ${ }^{159}$ most corporate acquisitions are completed at a uniform price. Bidders generally buy target firms either in a "one-step" merger or asset sale approved by a majority of the target's shareholders ${ }^{160}$ or by acquiring voting control through a tender offer and then, as controlling shareholder, approving a "squeeze-out" merger at the same price. ${ }^{161}$

Acquiring shares at a uniform price costs substantially more than purchasing an equivalent number of shares through private or openmarket purchases. A bidder acquiring stock in individually negotiated transactions can price discriminate and offer high prices to moreoptimistic shareholders and low prices to relatively pessimistic shareholders, to reflect each group's differing reservation values. ${ }^{162}$ In an acquisi-

receive the highest consideration paid any one of them. See Securities Exchange Act of 1934, $\S$ 14(d)(7), 15 U.S.C. $\$ 78 \mathrm{n}$ (d)(7) (1988) ("best price rule"); Acquisitions of Substantial Amounts of Securities and Related Activities Undertaken During and Following a Tender Offer for Those Securities, Securities Exchange Act Release No. 24,976, [1987 Transfer Binder] Fed. Sec. L. Rep. (CCH) ף 82,422 (Oct. 1, 1987) (proposing regulation of street sweeps under Williams Act).

159. "Toehold" purchases usually amount to only a small percentage of the target's outstanding stock. See Office of the Chief Economist, Stock Trading Before the Announcement of TENDER Offers: Insider Trading OR Market Anticipation? 16 (1987) (hereinafter OCE REPORT] (finding bidders acquire average toehold of $7.4 \%$ of target's outstanding stock). Toeholds allow bidders to exercise some price discrimination. See infra notes 162-63 and accompanying text. They may also provide an opportunity to test demand elasticity to gauge the minimum premium required for the offer to succeed. See Coffee, supra note 5, at 1187 (toehold allows bidders to test the market); cf. Toms, supra note 156, at 557 (successful tender offerer must estimate the demand of the last necessary shareholder).

160. The bidder who buys through open-market purchases, private sales, or tender offer can expect that a significant fraction of the target's shareholders will decline to sell even at a premium. A merger (whether as an initial strategy or a mop-up tactic following the purchase of a controlling interest) forces minority shareholders to sell their shares.

161. In a "front-end loaded" tender offer, a bidder makes a premium tender offer accompanied by an announcement that if the offer succeeds, the bidder will force a squeeze-out merger at a lower price. That stratagem forces even those shareholders who think the offered price is too low to tender, for fear they will get stuck with an even lower price in a back-end merger. See Bebchuk, Tou'ard Undistorted Chaice and Equal Treatment in Corporate Takeovers, 98 Harv. L. REv. 1693 (1985) (prisoner's dilemma of two-tier offer). However, front-loaded offers are rare. Gilson, supra note 15, at 861 (in typical two-stage offers, price paid minority in freeze-out transaction is no lower than original offer and occasionally higher); Johnson \& Miller, supra note 138, at 846-47 (unfair two-tier offers infrequent). This may be because a number of states and corporations have adopted "fair price" provisions requiring that shareholders squeezed out in a back-end merger be paid the highest consideration paid by the bidder in the transactions which gave the bidder majority control. See Romano, The Political Economy of Stale Takeover Statutes, 73 VA. L. REv. 111, 117-18 (1987) (describing adoption by states of "popular" fair-price provisions). Front-loaded offers also tempt shareholder lawsuits or appraisal claims. See Toms, supra note 156, at $549 \mathrm{n.5}$ (writing in 1978 that while frontloaded offers are not proscribed, in practice shareholders "squeezed out" in second-step merger often receive same price for their shares, perhaps to avoid threat of litigation). Finally, the Delaware Supreme Court has found that a front-loaded offer may constitute a "threat" to shareholder interests that justifies target management's decision to reject the offer and pursue defensive strategies. Unocal Corp. v. Mesa Petroleum Co., 493 A.2d 946, 956 (Del. 1985).

162. Price discrimination may be a motive for acquiring a toehold position or, more rarely, undertaking a series of tender offers at steadily increasing prices. See supra note 159 and accompanying text (toeholds); supra note 157 (series of tender offers). 
tion at a uniform price, however, the bidder must pay the pessimists as much as the optimists. ${ }^{163}$

At first glance, the consumer surplus ${ }^{164}$ enjoyed by the relatively pessimistic shareholders who believe the premium offer exceeds the true value of their shares would seem to imply that mergers at a uniform premium price (or tender offers followed by a merger at the same premium) substantially benefit target shareholders. ${ }^{105}$ The flaw in this analysis is that it ignores the fate of the shareholders who do not want to sell their shares. Mergers and asset sales do not require unanimous shareholder approval. In many states, a mere majority is sufficient to approve such transactions. ${ }^{168}$ If the deal is approved, shareholders who voted against the transaction are forced to sell their shares along with those who voted in favor of it. Thus, individuals who have more-optimistic estimates of their stock's value become the victims of a less-optimistic majority's rule. ${ }^{167}$ Less-thanunanimous shareholder approval of merger and asset sales (whether as an initial one-step acquisition strategy or as a squeeze-out tactic following a tender offer that gives the bidder voting control) forces dissenting shareholders to part with their shares for a price they believe inadequate. From the perspective of dissenting shareholders, such transactions are valueestroying. ${ }^{188}$

The downward-sloping demand hypothesis thus indicates that bidders who acquire target companies at a uniform premium price "overpay" the

163. See Coffec, supra note 5, at 1184 (merger weakens bidder's ability to price discriminate; bidder must pay "the price demanded by the last marginal shareholder whose vote in favor of the merger is required").

164. Consumer surplus is the difference between the premium price paid and the subjective value of the shares to those shareholders who believe they are worth less than the premium price offered, although more than the earlier prevailing market price. See generally P. SAMueison \& W. NoRDHAUs, supra note 27 , at 456-58 (consumer surplus).

165. Such offers are "value-creating" in the sense that the subjective value of the target firm's stock to the bidder, as measured by the bidder's willingness to pay for it, exceeds the subjective value of the target's stock to shareholders who voluntarily agree to sell their holdings. See infra notes 206-09 and accompanying text (real versus subjective gains).

166. R. Gilson, supra note 5, at 506 (many commercial jurisdictions follow Delaware practice of majority vote; some, including New York, require two-thirds). The obvious advantage to less-thanunanimous sharcholder approval of mergers is that it avoids the risk that a target shareholder will resort to strategic behavior by "holding out" to be the last shareholder whose stock carries control. See infra notes 273-74 and accompanying text.

167. Shareholders who decline to tender their shares in response to a tender offer usually suffer the same fate. If the bidder makes a tender offer at a premium sufficient to induce large numbers of sharcholders to tender, the tender offerer acquires voting control in the target, and remaining shareholders again can be "squeezed out" via a back-end merger. See Toms, supra note 156, at 564 (outcomes of two-step and unitary mergers analogous).

168. See Baysinger \& Butler, supra note 54, at 1288-89 (when members of collective have differing preferences, takeovers raise conflicts of interest and dissenting shareholders may stand to lose); Carney, supra note 26, at 386 (if some degree of inelasticity in supply curve for target stock, transfers of control can impose costs on nontendering shareholders). "Value" in this sense means subjective value as measured by willingness to pay. See supra note 165 .

The subjective loss suffered by dissenting shareholders is even greater in a "front-end loaded" deal where remaining minority shareholders receive less for their shares in a back-end merger than the premium price paid by the bidder in the tender offer or negotiated purchase by which it acquired voting control. Sep supra note 161 and accompanying text. 
shareholders who enthusiastically vote to approve the merger and "underpay" the dissenters who are forced to sell if the deal goes through. ${ }^{168}$ Approving shareholders enjoy subjective gains while dissenting shareholders suffer subjective losses. ${ }^{170}$

169. See Carney, supra note 26 , at 354-55 n.60 (shareholders who tender voluntarily and receive price above that necessary to obtain their shares gain, while nontendering shareholders forced to sel! in back-end merger lose).

The text posits a bidder who has made a tender offer or merger at a premium sufficient to induce $51 \%$ of the target's shareholders to tender or vote favorably, followed by a merger that "squeezes out" dissenters at the same premium price. While that model describes many acquisitions, there are variations on that theme. For example, a bidder may acquire a large block of shares initially through openmarket or private purchases at prices below the premium offered. See supra note 159 and accompanying text (price-discriminating toehold purchases). The bidder may need to acquire two-thirds or greater shareholder approval. See infra note 202 (supermajority provisions). Finally, a bidder may pay a lower price in a back-end merger than he paid to acquire a controlling interest. See supra note 161 and accompanying text (front-loaded offers). Each of these variations alters the consumer surplus or subjective loss resulting from the takeover. See infra notes 198-205 and accompanying text (balancing surplus and loss to determine value of takeovers).

170.

FIGURE 3:

CONSUMER SURPLUS AND LOSS GENERATED BY UNIFORM PREMIUM SALE

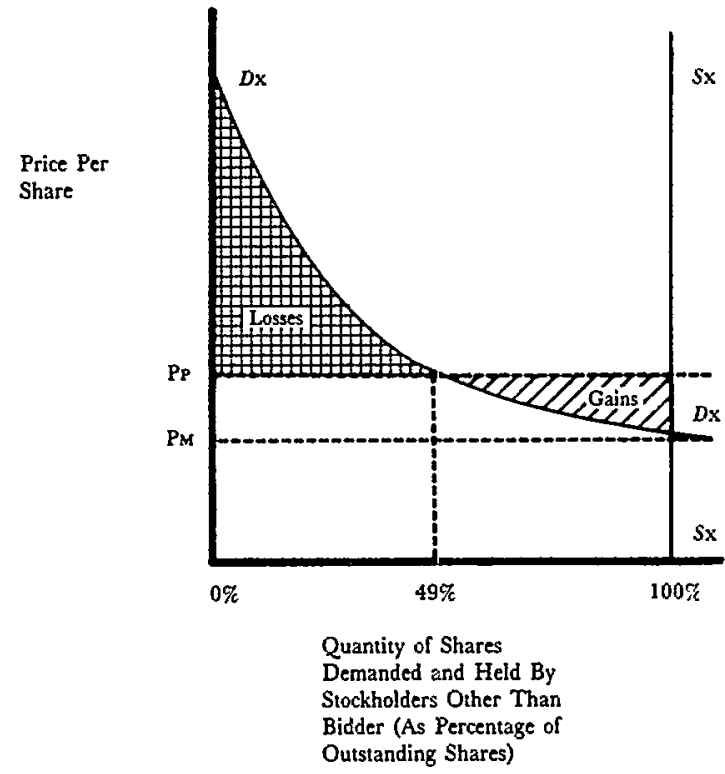

A tender offerer seeks to purchase $51 \%$ of firm X's outstanding shares at a uniform price. A premium price of $\mathrm{PP}$ over the market price of $\mathrm{PM}$ induces sufficient shareholders to sell. The bidder pays $\mathrm{Pp}$ to all tendering shareholders, generating a "consumer surplus" represented by the diagonally shaded area.

Once the bidder succeeds in gaining voting control of the target, the bidder forces a squeeze-out merger, also at a uniform price of PP per share. The merger imposes a subjective loss on the dissenting shareholders who make up the upper portion of the demand function $D \mathrm{x}-D \mathrm{x}$. The amount of the loss is represented by the cross-hatched area. 
The observation that uniform-price acquisitions result in windfall gains for some target shareholders and perceived losses for others carries at least two important implications for takeover regulation. First, it provides theoretical support for claims by target management that a premium bid that substantially exceeds market price may nevertheless be "inadequate." If investor demand for stocks is not perfectly elastic, the arguments of those who call for legal rules prohibiting target management from pursuing defensive tactics in response to premium bids are seriously flawed. ${ }^{\mathbf{1 7 1}}$ Second, it suggests that the phenomenon of acquisition premiums is virtually worthless as evidence of the social consequences of takeovers. A decade of commentary that attempts to gauge the value of acquisitions by examining their apparent returns to target shareholders has, quite simply, been looking in the wrong place.

Managements of target companies frequently respond to hostile premium bids with a wide array of defensive tactics designed to ward off such unwanted advances. Those tactics can range from a simple announcement that management deems the offered price inadequate, to a "scorched earth" policy of unfavorable acquisitions or asset sales which make the target an unattractive takeover candidate. ${ }^{172}$ The obvious and intended result of such tactics is to prevent the acquisition, at least at the offered price. ${ }^{173}$ Another foreseeable consequence, however, is that the target's shareholders may lose the opportunity to sell their shares at a premium. State courts have nevertheless allowed target management a fair degree of latitude to defend against and reject hostile premium bids. ${ }^{174}$

The scope granted target management in fending off unwanted bids was highlighted in Paramount Communications, Inc. v. Time, Inc. ${ }^{175}$ The directors of Time rejected a $\$ 200$ per share tender offer by Paramount as part of a policy of independence to protect Time's "culture."178

The total cost of the acquisition to the bidder is the premium price of $\mathrm{Pp}$, multiplied by the number of shares outstanding. This is represented by the total area beneath $\mathrm{Pp}$ and between the quantities of $0 \%$ and $100 \%$.

171. St' sources cited supra note 15 , infra notes $178-81$.

172. Ser generally R. CLARK, supra note 158, at 571-77 (describing defensive tactics); Carney, Cuntrolling Management Opportunism in the Market for Corporate Control: An Agency Cast Modvl, 1988 Wis. L. REv. 385, 392-402 (same).

173. Some commentators defend defensive tactics on the theory that they often lead to an even higher bid, from either the hostile bidder or a "white knight" competitor brought in by target management. Sir $R$. ClaRK, supra note 158, at 589-90. Where defensive strategies succeed, however-that is, where no takeover of any sort occurs-this argument is unavailable. See id. (arguing that, assuming premiums reflect net efficiency gains, defensive tactics harm shareholders by discouraging bids).

174. Sex Moran y. Household Int'l, Inc., 500 A.2d 1346, 1356-57 (Del. 1985) (preventive defensive measure, "poison pill," allowed if motivated in part by good-faith concern for corporation and its shareholders and if defensive measure is "reasonable" in relation to threat posed); Unocal Corp. v. Mesa Petroleum Co., 493 A.2d 946, 955 (Del. 1985) (defensive measure of stock repurchase in response to premium bid allowed under same standard).

175. Fed. Sec. L. Rep. (CCH) II 94,514 (Del. Ch. July 14, 1989), affd, 565 A.2d 280 (Del. July 24,1989 ).

176. Sep id. at p. 93,267 ("Time culture"). 
Instead, the Time board pursued an agreement with Warner Communications that would require Time to purchase fifty-one percent of Warner's stock and then acquire Warner in a back-end merger. The board expected Time's stock to trade at around $\$ 150$ a share following the merger. ${ }^{177}$

If efficient market prices reflect the true value of a firm's shares, a target's shareholders necessarily benefit from a premium offer like Paramount's. ${ }^{178}$ This is true whether premiums reflect anticipated efficiency gains from synergy or better management or reflect only overpayment by empire-building acquirers. ${ }^{179}$ Both the value-creating and overpayment theories of takeover premiums consequently suggest that target management violates its fiduciary duty to shareholders by resisting or rejecting a takeover bid at a premium price. ${ }^{180}$ On that theory, commentators have criticized harshly legal rules that allow target management to take defensive action against premium offers. ${ }^{181}$

In Paramount the Delaware Chancery acknowledged the argument that any offer higher than the price set by an efficient market necessarily benefits target shareholders. ${ }^{182}$ Nevertheless, the court declined to "elevate the theory of a single, efficient capital market to the dignity of a sacred text." ${ }^{\text {183 }}$ It upheld the discretion of Time's board to reject Paramount's offer as inadequate and to pursue the Warner acquisition. ${ }^{184}$

The heterogeneous beliefs hypothesis provides theoretical support for the Delaware Chancery's decision. If the demand for a target's stock is downward-sloping, a takeover at a premium price provides a windfall for those approving shareholders who believe that the offered price substan-

177. Id. at p. 93,272. This estimate was optimistic. Following announcement of the Time-Warner merger, but before the Paramount offer, the stock of Time was only trading in the \$105-\$122 range. Id. at p. 93,271.

178. See Easterbrook \& Fischel, Proper Role, supra note 6, at 1168 (tender offer at premium must benefit target's shareholders).

179. See Easterbrook \& Fischel, Corporate Control, supra note 6, at 707 (target management should not turn down premium to protect bidder from paying too much); Gilson, supra note 15, at 854 (premium acquisition that doesn't improve efficiency still benefits target shareholders, though acquiring firm's shareholders may be harmed).

180. See Dynamics Corp. of Am. v. CTS Corp., 794 F.2d. 250, 253 (7th Cir. 1986) (noting view that "market price of publicly traded stock impounds all available information about the value of the stock, and anyone who offers a higher price . . thereby offers an unequivocal benefit to the shareholders of the target firm, which management if it is really a fiduciary . . . should embrace rather than oppose"), affd in part and rev'd in relevant part, 481 U.S. 69 (1987).

181. See Baysinger \& Butler, supra note 54, at 1258 (many academics favor government prohibition of anti-takeover amendments); Coffee, supra note 5, at $1147 \mathrm{n} .2$ ("consensus" in academic community that most defensive measures are undesirable); see, e.g., Easterbrook \& Fischel, Proper Role, supra note 6, at 1164, 1201-04 (arguing that target management should be prohibited from resisting premium bids); see also Edgar v. MITE Corp., 457 U.S. 624, 643 (1982) (plurality opinion) (striking down Illinois anti-takeover law that blocked tender offers because "[s]hareholders are deprived of the opportunity to sell their shares at a premium [and the] reallocation of economic resources to their highest valued use, a process which can improve efficiency and competition, is hindered" (citing Easterbrook \& Fischel, Proper Role, supra)).

182. Fed. Sec. L. Rep. (CCH) II 94,514 at pp. 93,276-77 (Del. Ch. July 14, 1989), affd, 565 A.2d 280 (Del. July 24, 1989).

183. Id. at p. 93,277 .

184. Id. at pp. $93,272,93,275$. 
tially exceeds the actual value of their shares. ${ }^{185}$ It imposes a loss, however, upon the dissenters forced to sell their shares for less than they think they are worth. ${ }^{186}$ Management may judge that the bid, taken as a whole, inflicts a greater subjective loss on dissenting shareholders than the gain it provides for the approving majority. ${ }^{187}$ That is particularly likely to be true when the bidder has exercised price discrimination in acquiring a large toehold of target shares or intends a "front-loaded" deal that squeezes out dissenting minority shareholders at a lower price than the premium paid to acquire control..$^{188}$

Target management also may perceive a premium bid as contrary to the shareholders' interests if management believes that the subjective valuations which the shareholders currently attach to their stock substantially underestimate its actual value. Management's and shareholders' estimates of stock value are premised on their respective predictions for the firm's future. ${ }^{189}$ Those predictions can differ dramatically in a world of heterogeneous beliefs. ${ }^{180}$ As a general matter, we can expect that management has much greater knowledge of, access to, and experience with analyzing information relevant to the firm's future performance than the average shareholder does. ${ }^{101}$ It is therefore reasonable to suggest that management often may be the better judge of the stock's value.

That point should not be overstated, however. While a firm's directors may be better informed than the average shareholder, they also may have an obvious personal stake in the outcome of a takeover bid that can color their views of the merits of the offer. ${ }^{192} E x$ ante, we cannot be certain whether Time's management or Time's shareholders made more reasonable, accurate, and objective estimates of the firm's future value. ${ }^{193}$ At a

185. See supra text accompanying notes 162-65 (consumer surplus from uniform offer).

186. Ser supra text accornpanying notes 166-70 (dissenters' loss).

187. Cf. Paramount, at p. 93,284 ("corporation law does not operate on the theory that directors, in exercising their powers to manage the firm, are obligated to follow the wishes of a majority of shares"); sujura note 170 (Figure 3, weighing gains against losses).

188. Ser supra notes 159,161 (effects of price discrimination and front-loaded offers on shareholders' subjective gains and losses).

189. Sir supra notes 53-55 and accompanying text.

190. Ste Paramount, at p. 93,284 ("[r] easonable persons can and do disagree as to whether it is the better course from the shareholders' point of view collectively to cash out their stake in the company now at [a] premium cash price"). Management may disagree with shareholders' predictions even when the two groups base their opinions on the same information. Cf. Booth, supra note 39, at 664 (management whose beliefs differ from shareholders' may legitimately claim that offer is inadequate).

191. St' Paramount, at p. 93,277 (Time's directors could operate on theory that market price was wrong; "[n]o one, after all, has access to more information concerning the corporation's present and future condition"); Coffee, supra note 5, at 1230 (suggesting that target management may have better information concerning, and judgment of, true value of target's shares). But see Easterbrook \& Fischel, Proper Role, supra note 6, at 1194-1201 (criticizing under efficient markets theory judicial view that assessing economic merits of tender offer is peculiarly within ability of management).

192. See Paramount, at p. 93,269 (in negotiating Warner merger, Time directors ensured that surviving entity would be controlled in part by Time management and directors); Stout, supra note 3 , at 661-63 (agency cost when divergence of management and shareholder interests tempts management to favor personal interest).

193. The directors of Time rejected Paramount's bid ostensibly in the hope that, by pursuing the 
minimum, however, the downward-sloping demand hypothesis supports the Delaware Chancery's belief that the directors of Time may have "understood better than the public market for the firm's shares what the value of their firm was." 194

The uncertain value of takeover premiums as evidence of shareholder gains under the heterogeneous beliefs hypothesis carries implications far beyond the question of whether target management's decision to reject a premium bid is reasonable in any individual case. Advocates of sweeping regulatory reforms often focus on premiums as empirical support for their claims that something is amiss. ${ }^{195}$ According to value-creating theories, premiums indicate that corporate takeovers are a vital source of efficiency gains and that anti-takeover measures (including both defensive tactics adopted by target managements and protective state legislation passed at their behest) are socially harmful and should be limited. ${ }^{106}$ The bidderoverpayment theory sees premiums as evidence that entrenched management routinely wastes shareholders' money by buying targets at grossly inflated prices, a view that supports those who favor regulatory and market restraints on acquisitions. ${ }^{197}$ The downward-sloping demand hypothesis undermines both theories by suggesting that takeover premiums are of little value in determining whether takeovers produce social gains or losses.

One way to measure the benefits of takeovers is to consider whether they are "value-creating" in the sense that the total price paid by the acquirer exceeds the total subjective value that the target's shareholders attach to their holdings. ${ }^{198}$ If so, both parties to the transaction have obtained something they value more highly than the consideration they have

merger with Warner, they would increase the price of Time stock in a few years to well above the $\$ 200$ offered by Paramount. See Paramount, at p. 93,272 (Time's advisors predicted stock of TimeWarner entity would trade at around $\$ 150$ immediately following merger and rise to $\$ 208-\$ 402$ by 1993). Given that Time stock was trading below $\$ 125$ per share before the Paramount bid was announced, $i d$. at p. 93,271, such a strategy would appear to require an undue amount of optimism.

194. Paramount, at p. 93,277. But see Fischel, supra note 40, at 23 (management claim that company is worth more than bid price would seem to be "misleading" if market is efficient); Oesterle, The Negotiation Model of Tender Offer Defenses and the Delaware Supreme Court, 72 CoRnel. L. REv. 117, 124-25 (1986) (target management's claim to know more about company's value than current shareholders "flies in the face" of efficient market theory); Wang, supra note 2, at $398 \mathrm{n.182}$ (target management assertion that premium prices are "inadequate" is contrary to efficient market theory; courts that permit defensive tactics in response to premium offer implicitly accept claim that offer is inadequate).

195. See, e.g., Easterbrook \& Fischel, Proper Role, supra note 6, at 1164 (arguing against defensive tactics since target shareholders are clearly harmed if they lose opportunity for premium); see also Coffee, supra note 5, at 1162 (most commentators on takeovers begin with "striking fact" of preniums in excess of $100 \%$ ); $c f$. Macey, supra note 142, at 471 ("Ip]erhaps a complete answer to the question of whether takeovers benefit the national economy is contained in the evidence of the gains realized by those lucky shareholders whose firms are the subject of a tender offer").

196. See supra notes $129-35$ and accompanying text.

197. See supra notes $136-39$ and accompanying text.

198. See, e.g., Booth, supra note 39 , at 646 (transferring resources to those who value them most highly is "the very essence of economic efficiency"). 
given up, and both may be said to be better off. ${ }^{199}$ According to the downward-sloping-demand hypothesis, state laws that allow less-thanunanimous shareholder approval of mergers and asset sales force dissenting shareholders to give up their shares for a price they believe to be less than the shares' actual value. ${ }^{200}$ That creates the risk that a bidder can purchase a target for an aggregate price that is less than the total that the target's shareholders would demand in voluntary transactions. ${ }^{201}$ On the other hand, legal rules that make it difficult for bidders to price discriminate among selling shareholders force bidders to make windfall payments to those shareholders who believe the uniform price offered substantially exceeds the actual value of their shares. ${ }^{202}$

To some extent, the consumer surplus enjoyed by approving shareholders and the subjective loss suffered by dissenting shareholders in a merger can be expected to "cancel each other out." ${ }^{203}$ But because the exact shape and slope of the demand curves for different stocks is unknown, it is difficult to determine whether a bidder who acquires a target firm at a uniform price that overcompensates the approving majority and undercompensates the dissenters has paid a total price that exceeds, or falls short of, the aggregate subjective value that the target's shareholders attached to the property they have given up. ${ }^{204}$ Thus, the fact of a premium alone does

199. This analysis views the target's shareholders as a collective entity. Individual shareholders may believe the premium price is either a bargain or a bad deal; but in the aggregate, the total price the bidder pays exceeds the total price that the target's shareholders would demand in individually negotiated transactions. Cf. Carney, supra note 26, at 344 n.15 (discussing Kaldor-Hicks efficiency).

200. Sep supra notes $166-68$ and accompanying text. It is possible that the subjective losses suffered by dissenting shareholders in mergers substantially outweigh the consumer surpluses enjoyed by the majorities that approve them. This is especially likely if the bidder either pays little consumer surplus to the approving majority or imposes great losses on the dissenting minority. An example of the first situation occurs when the bidder successfully "price discriminates" in purchasing a control block on the open market or through a series of tender offers at ever-increasing prices. See supra notes 157-62 and accompanying text. An example of the second situation is a front-loaded deal in which shareholders who tender a controlling interest receive a higher price for their shares than the dissenters subsequently receive in the "squeeze-out" merger. See supra note 161 and accompanying text.

201. See Carney, supra note 26, at 352-54, 367 n.125 (if bidders can acquire firms for less than aggregate reservation prices that target's shareholders attach to their shares, bidders may anticipate gains in the form of pure wealth transfer from target's shareholders, creating risk of inefficient transactions).

202. Ser supra notes $162-65$ and accompanying text. The necessity of offering a uniform price sufficiently high to induce a majority of shareholders to vote favorably may force bidders to pay more than the sum of the target shareholders' reservation prices. This is especially likely when bidders either pay a great deal of consumer surplus to the approving majority or impose only small losses on the dissenting minority. An example of the first situation would be when the target had a "supermajority" voting provision requiring two-thirds or greater shareholder approval for a merger. The larger the proportion of shares a bidder must purchase to gain control, the larger the premium the bidder must pay. See Carney, supra note 26, at 374-78 (supermajority rules). An example of the second situation would occur if appraisal statutes allowed dissenting shareholders an appraised "value" for their shares which exceeded the premium price paid in the merger or tender offer. See infra notes 299-300 and accompanying text.

203. If so, those two market distortions are an example of the economists' "theory of the second best"-two sets of inefficient rules that, by virtue of their counteraction, produce a result more satisfactory than if either one were "reformed" alone. See Lipsey \& Lancaster, The General Theory of the Second Best, 24 Rev. Econ. Stud. 11 (1956-57).

204. Because the slope of the demand function is uncertain and may change over different por- 
not tell us whether a target's shareholders, on average, "gain" from selling at a premium. ${ }^{205}$

The task of determining whether takeovers are productive or destructive is made still more difficult by the fact that the subjective gains of bidders and target shareholders, as measured by the difference between their reservation prices for the target's shares and the price they actually pay or receive, may bear an uncertain relationship to "real" gains in productivity. ${ }^{208}$ In a world of rational, homogeneous beliefs, a bidder would only value a target's stock more highly than its current owners if the bidder expected to increase the target's earnings. ${ }^{207}$ In the real world, the bidder who values a target more highly may simply be mistaken. Because a successful acquirer has, in effect, won an auction, bidder error is skewed towards over-optimism - the proverbial "winner's curse."208 Takeovers in which the bidder pays a total price exceeding the aggregate value that the target's current stockholders attach to their shares thus may create "value" without actually improving earnings or productivity. ${ }^{209}$

The phenomenon of takeover premiums, alone, therefore tells us almost nothing about whether takeovers produce gains or losses for society in general or target shareholders in particular. ${ }^{210}$ And once premiums are rejected as unreliable evidence, there is no longer an easy answer to the questions of whether takeover reform is desirable or what direction it should take. Other evidence on the social value of acquisitions is far more equivocal. Accounting studies examining targets' reported earnings have failed to find any indication that acquisitions on average improve the performance of target firms. ${ }^{211}$ Similarly, tests of the impact of acquisition announcements on bidder share price suggest that acquiring firms' share-

tions of the demand curve, there is no way to be sure of the relationship between surplus and loss. Carney, supra note 26, at 354-55 \& n.60. But see Booth, supra note 39, at 654-55 n.82 (assuming "idealized" demand function as straight line so that surplus and loss cancel out).

205. Of course, the bidding firm must anticipate that the value of the target exceeds the merger price, or the acquisition would not be pursued. But if target shareholders suffer an overall subjective loss that outweighs the bidder's anticipated subjective gains, the transaction is value-destructive.

206. See Coffee, supra note 5 , at 1230 (bidder's premium offer may mean only that bidder "thinks it can do better than the incumbent management"; this is "individual and potentially idiosyncratic judgment" (emphasis in original)).

207. See supra notes 29-36, 132-33 and accompanying text.

208. A bidder will succeed only if he values a firm more highly (and therefore is willing to pay a higher price) than competing bidders and the investors who already hold it. See Flamm v. Eberstadt, 814 F.2d 1169, 1176 (7th Cir. 1987), cert. denied, 484 U.S. 853 (1988) ("winner's curse" of bidder who wins auction because he alone placed unrealistically high value on auctioned assets).

209. See Coffee, supra note 5, at 1167-68 (if bidders pay high prices out of over-optimism, net result is not efficiency gain but only wealth transfer to target shareholders).

210. Premium offers provide subjective gains to those target shareholders who approve them and subjective losses to those who dissent. There is no way to determine, a priori, whether the gains outweigh the losses or the losses outweigh the gains. Bidders almost surely anticipate gains from acquisitions, or they would not pursue them. But in the long run, anticipated gains may never materialize in the form of real earnings and profits.

211. See supra note 143 and accompanying text. 
holders do not consistently view acquisitions as either helpful or harmful. ${ }^{212}$

The heterogeneous beliefs hypothesis consequently recommends a far greater degree of agnosticism on the subject of the social value of acquisitions than has characterized the takeover debate thus far. ${ }^{213}$ Takeover premiums that reflect nothing more than the natural consequence of a downward-sloping demand function tell us little about the efficiency implications of takeovers in general or any individual transaction in particular. If the heterogeneous beliefs hypothesis is correct, the current debate over whether and how takeover bids and defenses should be regulated badly needs a new focus. Corporate acquisitions may or may not produce gains for shareholders and society. But policymakers who look to the existence of takeover premiums to answer that crucial question risk being sorely misled.

\section{B. Insider Trading}

A second area of corporation law in which assumptions of demand elasticity play a fundamental role is the regulation of "insider trading" on the basis of nonpublic information. Price pressure is the key to the controversial argument that insider trading improves the efficiency of the stock market. That argument has inspired academics to propose that insider trading be legalized ${ }^{214}$ and the Supreme Court to narrow the scope of insider liability. ${ }^{215}$ The ability of large transactions to move prices is also important in determining who is harmed by, and therefore who may bring suit against, insider traders. The potential civil liability of insiders for

212. Ste authorities cited supra note 1. There is a fair amount of dispersion in the data. See Black, supra note 1, at 603 (average returns to bidders in recent years appear to be zero; however, great deal of "scatter" suggests that average is result of both "good" and "bad" takeovers cancelling each other out).

213. The difficulty of assessing the economic impact of takeovers is increased because takeovers and takeover bids carry efficiency consequences beyond the outcome of individual transactions. For example, neither financial accounting nor bidder share price studies tell us much about the economic importance of a credible threat of a takeover: that threat may keep target management on its toes, or simply distract and demoralize it. Compare Coffee, supra note 5, at 1238-43 (describing "excess" deterrence and problem of demoralization) with Easterbrook \& Fischel, Proper Role, supra note 6, at 1174 (target shareholders benefit even if takeover never occurs because threat of takeover improves management performance).

214. Macey, From Faimess to Contract: The New Direction of the Rules Against Insider Trading, 13 Hofstra L. Rev. 9, 31 n.110 (1984); see, e.g., H. Manne, Insider Trading and the STOCK MARKeT 80-90 (1966); Fischel, Insider Trading and Invesiment Analysts: An Economic Analysis of Dirks v. Securities Exchange Commission, 13 Hofstra L. Rev. 127, 133 (1984); Manne, Insider Trading and the Law Professors, 23 VAND. L. Rev. 547, 565 (1970); Wu, An Economist Lonks at Section 16 of the Securities Exchange Act of 1934, 68 Colum. L. REv. 260, 265-69 (1968).

215. Ste Dirks v. SEC, 463 U.S. 646, 658 (1983) (narrow rule of tipper-tippee liability necessary to protect market efficiency); Freeman v. Decio, 584 F.2d 186, 190, 196 (7th Gir. 1978) (declining to recognize state law claim for insider trading and noting that prohibition causes loss in market efficiency); ste also Stout, supra note 3, at 624-27 (concern for efficiency has influenced scope of insider trading prohibition). 
price shifts resulting from their trading matters not only to the parties involved in such actions but also to regulators who must rely on civil lawsuits as a supplement to criminal enforcement. ${ }^{216}$

Insider trading in a stock is often accompanied by a significant change in its market price. ${ }^{217}$ At first blush, such changes appear to evidence price pressure. According to the horizontal-demand hypothesis, however, even massive transactions by insiders should not affect market quotations. If the demand for stock is perfectly elastic, insider buying or selling, alone, is incapable of shifting prices. ${ }^{218}$

Scholars who rely on the CAPM consequently have been pressed to find other explanations for price movements that appear to be caused by insider trading. Some argue that price changes occur because the nonpublic information upon which the insider trades has somehow leaked into the public domain. ${ }^{219}$ The question then arises: Who is the source of the leak? The insider who hopes to profit from nonpublic information has obvious incentives to conceal it, at least until he has finished trading on it. ${ }^{220}$ Other sources within the corporation may be at fault. But unless firms are virtual sieves for information, it seems curious that insider trading activity should be so consistently matched by leaks from unrelated sources. ${ }^{221}$

A recent SEG-sponsored study of the price run-ups commonly associated with takeover bids provides evidence that information leaks alone

216. See H.R. Rep. No. 910, 100th Cong., 2d Sess. 26 (1988) (private rights of action are important enforcement supplement).

217. See, e.g., Dirks, 463 U.S. at $649-50$ (insider's tip led to sales of $\$ 16$ million, while stock price dropped from $\$ 26$ to $\$ 15$ ); SEC v. Texas Gulf Sulphur Co., 401 F.2d 833, 840, 847 (2d Cir. 1968), cert. denied, 394 U.S. 976 (1969) (extensive insider purchases accompanied by price increase). See generally Stout, supra note 3, at 622-27 (role of insider trading in improving efficiency of prices).

218. See Carney, supra note 10, at 877 (increase in trading volume of insiders or others should not influence market); Easterbrook, supra note 10, at 335-36 (because supply of stock highly elastic, insider trading should not move prices); Note, Toward a Definition of Insider Trading, 41 STaN. L. REv. 377, 395 (1989) (insider trading should not move prices).

219. In other words, the cause of the change is not price pressure but rumors which spur the market to reevaluate the stock. See Easterbrook, supra note 10, at 336 (insider trading leads to price adjustments only to extent that insider's secret has leaked to market); Garten, supra note 124, at 630 (leaks and speculation are more likely causes of price shifts before takeover bid than price pressure from insider trading).

220. See Carney, supra note 10, at 886 (insiders "have every reason" to conceal their presence in market); $c f$. Garten, supra note 124, at 630 n.258 (because insiders hope to profit from secret information, they will avoid inducing price change).

Where the insider is purchasing on nonpublic good news (as opposed to selling on bad news), the insider may have an incentive to leak the information to raise market prices and sell at a profit. Where the news is due to be disclosed in any event, however, the insider has little reason to draw attention to herself and her apparent prescience by passing the information along. See, e.g., Note, Insider Trading and the Corporate Acquirer: Private Actions Under Rule 10b-5 Against Agents Who Trade on Misappropriated Information, 56 GEo. WASH. L. REv. 600, 601 (1988) (describing investment banker Dennis Levine's insider trading in stock of takeover target; to avoid detection, Levine scattered purchases over five-week period preceding tender offer and then sold on day tender offer was announced).

221. Especially in the case of a firm contemplating a takeover bid, there is every incentive to prevent a leak that would put target management on notice and raise the cost of acquiring a tochold position in the target's stock. But see Garten, supra note 124, at 637 (firms' apparent carelessness in transmitting sensitive information). 
cannot explain the changes in stock price that accompany insider trading. ${ }^{222}$ The announcement of a merger or tender offer at a premium price is often preceded by a substantial increase in the market quotation for the target's stock. Those increases are perceived as evidence that insider trading on the news of forthcoming bids is common and that it does move stock prices. ${ }^{23}$ The SEC study sought to test the proposition that pre-bid price increases result not from insider trading, but from the market's anticipation of the upcoming bid and incorporation of that information into stock prices. It identified a number of potential information sources, including media reports of rumors and potential bidders' purchases of toehold positions in the target's stock. ${ }^{24}$ While those factors were found to be associated with price run-ups, ${ }^{225}$ the study concluded that the information-carrying signals examined were "unable to explain a great deal of the pre-bid trading." 226 That finding suggests there is more to the phenomenon of pre-bid run-ups than the simple leak of information.

Some commentators supplement the information hypothesis by arguing that insider trading also moves prices because observant investors "decode" information from the fact of the trading itself. ${ }^{227}$ A sudden increase in trading volume, an unexplained price shift, or the trader's identity may signal the market that the game is afoot. The flaw in the signaling theory is that insiders and their tippees have strong incentives to hide the fact of their illegal trading as well as the nonpublic information that motivates it. ${ }^{228}$ Anonymous trading through a broker or other surrogate easily ob-

222. SeP OCE REPORT, supra note 159, at 33.

223. Id. at $1-2$.

224. Id. at 5-7. Of course, if demand is not perfectly elastic, the acquisition of a toehold will drive price upward not only because it carries information to the market, but also because such large purchases exert price pressure. See Coffee, supra note 5, at 1187 n.117 (if target's price rises while bidder acquires toehold, this is either because supply curve is upward-sloping or because news is leaking; "both seem likely"). However, if stocks on average demonstrate a degree of elasticity that approximates unit elasticity, see supra notes 105-07 and accompanying text, it seems unlikely that toehold purchases averaging a small percentage of the target's stock explain the much larger average price increases documented in the SEC study. See OCE REPORT, supra note 159, at table 4 (toehold purchases averaging eight percent accompanied by pre-bid run-up averaging $43 \%$ of eventual premium; run-up occurred even where bidder made no toehold acquisition).

225. Takeover bids preceded by media speculation experienced price run-ups averaging $50 \%$ of the offered premium on the day before announcement, while bids with no rumors saw a $33 \%$ run-up. The study concluded that speculation accounted for roughly one-third of the price increases observed. Foothold acquisitions were also found to be slightly correlated with the degree of run-up experienced. OCE REPORT, supra note 159 , at 3 .

226. Id, at 33 .

227. See, e.g., Carney, supra note 10, at 889-91 ("detected" trading); Gilson \& Kraakman, supra note 3 , at 629-35 ("derivatively informed" trading through "decoding").

228. Because insider trading prosecutions often begin when authorities detect unusual trading patterns, insider traders have great motivation to hide their purchases. See Easterbrook, supra note 10, at 314 (large trades invite attention and prosecution). Moreover, if other traders learn of the information upon which the insider is trading, whether through a direct leak or signaling, the market price will adjust and the insider's opportunity for profit is diminished. See Garten, supra note 124, at $630 \mathrm{n} .258$ (insiders want to avoid detection of their trading to preserve profits and avoid arousing suspicions of SEC); see also Carlton \& Fischel, The Regulation of Insider Trading, 35 STAN. L. REv. 857, 868 (1983) (insider traders camouflage trading). 
scures the identity of the trader. ${ }^{228}$ And an increase in trading volume, alone, carries little information. In the absence of a price shift, observers are unable to determine even whether an increase in volume is sparked by heavy selling or heavy buying. ${ }^{230}$ Finally, while a price shift may carry information to the market, in the absence of price pressure there is no reason for an insider's transactions to move prices significantly. ${ }^{231}$ It therefore seems unlikely that investors can "decode" much information from transactions that may, or may not, be illegal insider trading. ${ }^{\mathbf{2 3 2}}$

The information and signaling hypotheses provide only partial and unsatisfactory solutions to the price movements associated with insider trading. Once the possibility of price pressure is added to those theories, however, the problem of explaining price changes becomes far more tractable.

When insiders learn of nonpublic information concerning a firm, they become interested in buying or selling its shares. Their interest may be substantial. In some cases, transactions by insiders and their tippees have more than doubled the volume of trading in a particular stock. ${ }^{233}$ The downward-sloping demand hypothesis predicts that when the demand of insiders and tippees is added to or subtracted from preexisting investor demand, the aggregate demand function shifts outward or inward. Trading by insiders and tippees thus changes equilibrium price. ${ }^{234}$

The price shift is amplified if insider purchases or sales move price so significantly that other investors observe the price change and decode in-

229. See Carney, supra note 10, at 887 (insiders trade anonymously); Garten, supra note 124, at 581 n.33 (questioning belief that outsiders can identify who and why of insider trading, as even SEC has difficulty); Gilson \& Kraakman, supra note 3, at 574 ("trade decoding" limited by ability of uninformed traders to identify informed traders).

230. For every transaction there is both a buyer and a seller. If an insider has sufficient time to space out his trades so that liquidity costs do not shift prices significantly, see supra note 94 , observers will not be able to tell whether the heavy volume is due to buying or selling. See Carney, supra note 10 , at 888 (if increase in volume does not move price, insider trading does not signal market); see also Seligman, The Reformulation of Federal Securities Law Concerning Nonpublic Infornation, 73 GEo. L.J. 1083, 1096-97 (1985) (large transactions by insiders may communicate information to market, but because who is buying or why remains unknown, market's ability to infer information from trading is impaired).

231. See Gilson \& Kraakman, supra note 3, at 574-76 (describing "price decoding"). The usefulness of price-decoding is also limited by investor uncertainty as to why price might be changing. A price increase could be due to the market receiving new information, or to a buying spree by some foolish investor, as well as to insider trading. See Cox, Insider Trading and Contracting: A Critical Response to the "Chicago School", 1986 Duke L.J. 628, 647-48 (even if insider trading moves price, other investors may attribute change to efforts of outside analysts).

232. See Carney, supra note 10 , at $886-89$ (insider trading generally fails to signal market); Cox, supra note 231, at 646 (insider trading has too much "noise" to be good signal); Gilson \& Kraakman, supra note 3, at 630-32 (insider trading provides poor and ambiguous signals).

233. See FMC Corp. v. Boesky, 852 F.2d 981, 984 (7th Cir. 1988) (trading by Ivan Boesky accounted for more than half of volume during period when stock price rose "sharply"); see also Dirks v. SEC, 463 U.S. 646, 649 (1983) (tippee sales of $\$ 16$ million); Litton Indus. v. Lehman Bros. Kuhn Loeb, 709 .F. Supp. 438, 441 (S.D.N.Y. 1989) (Dennis Levine's "massive" insider trading in takeover target); Keown \& Pinkerton, Merger Announcements and Insider Trading Activity: An Empirical Investigation, $36 \mathrm{~J}$. FIN. 855, 863 (1981) (weekly volume of trading in targets $247 \%$ higher in week before acquisition announcement than three months prior).

234. FIGURE 4: 
formation from it. ${ }^{238}$ Thus, under the downward-sloping demand hypothesis, insider transactions significantly change prevailing market prices both because the transactions themselves exert price pressure and because the resulting price movement reinforces the signaling effects of insider buying or selling.

That possibility carries at least two significant consequences for the regulation of insider trading. First, it lays a theoretical foundation for the claim, first raised by Professor Manne, that trading on nonpublic information is beneficial because it improves the efficiency of the stock market by moving prices in the "correct" direction. ${ }^{236}$ That claim has fueled two

FIGURE 4

SHIFT IN MARKET PRICE RESULTING FROM INSIDER

TRADING

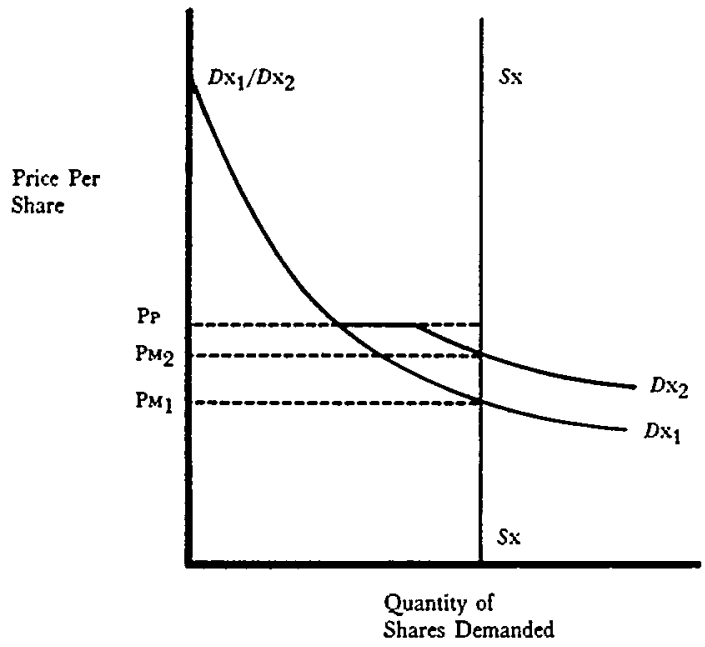

Before insider trading, an equilibrium price of $\mathrm{PM}_{1}$ is set by the intersection between a fixed supply function $S \mathrm{X}-S \mathrm{x}$ for the outstanding stock of firm $\mathrm{X}$ and downward-sloping demand function $D \mathrm{x}_{1}-D \mathrm{x}_{1}$. When insiders learn that the firm may be the subject of a takeover bid at premium price PP, they become interested in buying stock in $\mathrm{X}$. The new demand of insider traders is added to existing demand, shifting the aggregate demand function from $D \mathrm{x}_{1}-D \mathrm{x}_{1}$ to $D \mathrm{x}_{2}-D \mathrm{x}_{2}$. This shifts the equilibrium market price from $\mathrm{PM}_{2}$ up to $\mathrm{PM}_{2}$ per share.

The new demand curve $D \mathrm{x}_{2}-D \mathrm{x}_{2}$ is kinked because insider traders are only interested in buying shares of $\mathrm{X}$ at prices between $\mathrm{PM}_{1}$ and the anticipated premium price of $\mathrm{PP}$. The curve remains downward-sloping on the assumption that insider traders, like other investors, are risk-averse and have downward-sloping individual demand functions.

235. See supra notes $227-32$ and accompanying text. The possibility of successful price-decading explains how insider trading can induce disproportionate price changes that exceed the volume of insider purchases of outstanding stock. See supra notes 105-06 and accompanying text (average unit inelasticity).

236. Sep H. MANNE, supra note 214 , at $80-90$. Improved accuracy in stock prices is perceived as 
decades of debate over the wisdom of legalizing insider trading. ${ }^{237}$ Contemporary scholars criticize Manne's thesis on the ground that the demand for stock should be perfectly elastic. ${ }^{238}$ The wisdom of legalizing insider trading may be challenged on the ground that such trading creates perverse incentives ${ }^{\mathbf{2 3 9}}$ or that improved stock market efficiency is unimportant as a policy goal. ${ }^{240}$ But a downward-sloping demand function provides ample theoretical support for a causal link between insider trading and "efficient" price changes.

Second, the existence of price pressure is important in determining who is harmed when an insider trades on nonpublic information. In addition to the investors who actually buy from or sell to the insider, ${ }^{241}$ the potential victims of insider trading include third parties whose transactions are affected by the insider's activity. ${ }^{\mathbf{2 4 2}}$ The paradigmatic example is a takeover bidder who pays more for an acquisition because insider buying has driven up the target's market price. ${ }^{243}$ A flurry of recent prosecutions against insiders who allegedly traded in the stock of takeover targets on the basis of confidential news of premium bids has created a new sensitivity to the effects of insider trading on acquiring firms. ${ }^{244}$ It has also in-

a desirable policy goal on the assumption that stock prices influence the allocation of capital and other scarce resources. The argument that insider trading improves the efficiency of the stock market is consequently viewed as one of the strongest arguments in support of legalizing such trading. Manne, supra note 214, at 565; Stout, supra note 3 , at 662,706 n.759.

237. See, e.g., Carlton \& Fischel, supra note 228, at 866-68 (insider trading benefits efficiency); Wu, supra note 214, at 265-69 (1968) (insider trading is efficient). But see Cox, supra note 231, at 646-48 (criticizing view that insider trading improves market accuracy); Schotland, Unsafe at Any Price: A Reply to Manne, 53 VA. L. Rev. 1425, 1448-49 (1967) (because insider trading creates incentive to withhold information, it harms efficiency).

238. See, e.g., Easterbrook, supra note 10, at 335-36 (perfectly elastic demand implies insider will not improve market efficiency unless insider's secret leaks out); Gilson \& Kraakman, supra note 3, at 629-34 (demand perfectly elastic, so insider trading a weak mechanism for price changes); Note, supra note 218, at 394-95 (insider trading can only improve efficiency through signaling; suggesting this does not occur); cf. Cox, supra note 231, at 647-48 (suggesting insider purchases may not significantly move price); Seligman, supra note 230, at 1083, 1096 (insider trading will not make market more efficient because it does not have significant impact on price).

239. See Levmore, Securities and Secrets: Insider Trading and the Law of Contracts, 68 VA. L. REv. 117, 149 (1982) (incentive to create bad news which provides trading opportunity); Schotland, supra note 237, at 1448-49 (incentives to withhold information from market, harming efficiency). Insider trading is also criticized as harming investor "confidence" in the market. See H.R. REP. No. 910 , supra note 216 , at 8 (insider trading harms confidence in market integrity).

240. See Stout, supra note 3, at 618 (increase in market efficiency produces little social benefit and should not be goal of securities policy).

241. See Wang, Trading on Material Nonpublic Information on Impersonal Stock Markets: Who Is Harmed and Who Can Sue Whom under SEC Rule 10b-5?, 54 S. CaL. L. Rev. 1217, 1232-36 (1981) (discussing potential harms to those in privity with insider).

242. See id. at 1239-40 (discussing effects of insider-induced price changes on parties transacting in securities markets at about same time).

243. See United States v. Newman, 664 F.2d 12, 17-18 (2d Cir. 1981), cert. denied, 464 U.S. 863 (1983) (artificial inflation of target's price due to insider trading harmful to offering company).

244. See, e.g., H.R. REP. No. 910, supra note 216, at 11-13, 28-29 (describing "high-profile" insider trading cases and noting that such trading may increase bidder's cost of takeover); Note, Insider Trading by Intermediaries: A Contract Remedy for Acquirers' Increased Costs of Takeot'ers, 97 YALE L.J. 115, 115-16 \& n.1 (1987) [hereinafter Note, Contract Remedy] (recent "series of scandals" involving more than a dozen government enforcement actions against insiders who traded and tipped on news of takeover bids; such trading can increase cost of bid); Note, supra note 220, at 603-04, 637 
spired ground-breaking civil lawsuits by acquiring firms seeking damages from insiders whose trading allegedly increased the cost of an acquisition. ${ }^{245}$

Litton Industries, Inc. v. Lehman Brothers Kuhn Loeb Inc. illustrates the novel causation questions raised by these types of actions. ${ }^{246}$ In November of 1982, Litton Industries decided to expand its defense electronics business by acquiring Itek, a firm specializing in electronic warfare. Litton retained Lehman Brothers as its investment banker and began negotiating with Itek over the price of the proposed sale. ${ }^{247}$ Unbeknownst to Litton, an employee of Lehman Brothers-Dennis Levine-conducted "massive amounts of trading" in Itek during the merger negotiations. ${ }^{248}$ According to Litton, Levine's buying spree drove the market price of Itek substantially higher, forcing Litton to revise its initial bid upward from forty to forty-eight dollars a share. ${ }^{248}$ The offer was accepted by Itek, and Levine sold his stock for a hefty profit.

In its complaint, Litton alleged that insider trading by Levine and related defendants artificially raised the market price for Itek, causing Litton to pay thirty million dollars more for the acquisition than it otherwise would have. ${ }^{250}$ Scholars who rely upon the CAPM would dismiss such claims as unfounded. If the demand for stock in a target firm is perfectly elastic, insider trading cannot, alone, increase market price. ${ }^{251}$

In contrast, the downward-sloping demand hypothesis provides a direct causal link between insider buying and increased acquisition costs. Substantial insider purchases shift the market price of the target's stock upward in a manner that signals other investors. Trade-decoding arbitrageurs enter the market and drive prices up still further. The resulting substantial increase in the market quotations for the target's shares can influence the terms of the bidder's offer. A rational bidder contemplating a merger or tender offer tries to estimate the minimum premium it must offer to induce a sufficient percentage of the target's shareholders to either

(noting increase in insider trading on news of tender offers and discussing harms to acquiring firms).

245. See FMC Corp. v. Boesky, 852 F.2d 981, 982 (7th Gir. 1988) (claim that insider traders who reaped alleged profits of $\$ 20$ million caused firm to pay $\$ 235$ million more in recapitalization); Anheuser-Busch Co., Inc. v. Thayer, CA3-85-0794-R (N.D. Tex. 1986) (cited in H.R. REP. No. 910 , supra note 216, at 28) (claim that insider Paul Thayer caused Anheuser-Busch to pay $\$ 80$ million more in acquisition); Note, supra note 220, at 602 \& n.22, 603 (describing similar lawsuits, suggesting numerous others likely to be brought in future).

246. 709 F. Supp. 438 (S.D.N.Y. 1989); sep Note, supra note 220, at 603 (Litton raises issue of insider trading liability to acquiring firm for first time).

247. Lehman Brothers Kuhn Loeb is now known as Shearson Lehman Brothers. 709 F. Supp. at 440.

248. Levine allegedly made $\$ 13$ million buying stock in at least 54 companies on the basis of confidential information concerning upcoming premium bids. H.R. REP. No. 910, supra note 216, at 12.

249. 709 F. Supp. at 448 . The sale took the form of a friendly tender offer at $\$ 48$ a share to be followed by a cash merger at the same price. Id. at 441 .

250. Note, supra note 220 , at 602 (citing complaint).

251. See authorities cited supra notes $218,232,238$. 
vote favorably (in the case of a merger) or to tender their shares (in the case of a tender offer) ${ }^{262}$ One of the factors relevant to that calculus is the current market price for the target's stock-that is, the reservation price of the least optimistic of the target's current shareholders. ${ }^{253}$ If the market price rises, the bidder may perceive this as evidence that the demand function for the stock has shifted outward. ${ }^{254}$ If the bidder believes the acquisition is still attractive, it will offer a higher premium, assuming this is necessary to acquire the requisite percentage of shares or votes. ${ }^{265}$

The heterogeneous beliefs hypothesis thus provides a causal link between insider purchases and bidder injury. That connection is crucial to an acquiring firm's ability to recover damages from insider traders under state or Federal law. ${ }^{250}$ And potential liability to acquiring firms is of interest not only to insiders weighing the risks and rewards of illegal trading, but also to regulators seeking to enforce the rules against insider trading.

The wave of recent insider trading scandals and the accompanying public perception that such trading is endemic reflect the failure of current law to deter insider trading. ${ }^{257}$ Limited public resources have hamstrung authorities charged with criminal enforcement of the prohibition against trading on nonpublic information. ${ }^{288}$ Civil suits brought by victims of in-

252. See supra notes 160-69 and accompanying text. Because the exact shape and slope of the demand function for the target's stock is unknown, the bidder cannot know with certainty what that minimum price would be.

253. See 709 F. Supp. at $448-49$ (one factor considered by investment bankers setting price for acquisition was market price of target's stock); Note, Contract Remedy, supra note 244, at 129 (bidders set offer at particular premium over market price). But see Litton, 709 F. Supp. at 446 (finding that Litton's offer price was not determined solely on basis of market price plus premium); Garten, supra note 124, at 631 (bidders may take account of likely insider trading in setting offer price).

254. If the least-optimistic shareholder has shifted her opinion of stock value upwards, a rational bidder might well conclude that she has received new information which would cause the subjective estimates of other shareholders to increase as well.

255. Alternatively, the bidder may abandon the acquisition, estimating that the cost of a successful offer would be too high.

256. Acquiring firms seeking damages from insider traders face a number of factual and procedural obstacles in addition to showing that price pressure affected the target's market price. For example, because there is no express Federal cause of action for acquiring firms, there is some question about whether an implied cause of action is available under Federal or state law. See Note, Contract Remedy, supra note 244, at 120-23 (discussing possible causes of action and obstacles to recovery). But see H.R. REP. No. 910, supra note 216, at 27-28 (House committee believes acquiring firms have implied cause of action under Rule 10b-5). Moreover, an acquirer must prove not only that insider trading increased the market price for the target's stock, but that the rise in market price increased the cost of the acquisition. See Litton, 709 F. Supp. 438, 439 (summary judgment granted on grounds that plaintiff had failed to show that alleged increase in market price affected terms of offer).

257. Sep H.R. REP. No. 910, supra note 216, at 11-14 (describing prosecutions against Ivan Boesky, Dennis Levine, Martin Siegel, "Yuppie Five" and others, and noting dramatic increase in insider trading scandals that are "far more than the transgressions of a few individuals"); Garten, supra note 124, at 573 (insider trading "is everywhere", media coverage and court cases suggest "epidemic").

258. See H.R. REP. No. 910 , supra note 216 , at 14 (greatest problem in battle against insider trading is lack of resources). 
sider trading have the potential to be an important supplement to those efforts. $^{258}$

Present law, however, limits the damages that can be recovered by individuals who stand on the opposite side of a transaction with an insider. Damages are limited to the difference between the price such persons paid or received and the price they would have paid or received had the insider disclosed to them his nonpublic information. ${ }^{260}$ In other words, the insider must return to the plaintiff the amount of loss the insider avoided by selling prematurely on the basis of undisclosed bad news or his profits from buying on unannounced good news. Requiring insiders to pay back their illegal profits if they are caught adds little incentive for individuals to conform their behavior to the requirements of the law. ${ }^{261}$

The limited damages awarded in traditional insider trading cases also reduce the utility of civil suits in encouraging investment banking firms, brokerage houses, law firms, and similar businesses to police against insider trading among their employees. ${ }^{262}$ Most insider traders gain access to nonpublic information through their employment in the securities industry. ${ }^{263}$ Federal law exposes employers to possible derivative civil liability for the insider trading of their employees, ${ }^{264}$ and the current regulatory scheme relies in great part upon in-house "compliance departments" to monitor employees' activities and guard against abuses. ${ }^{265}$ Recent scandals

259. Id. at 26; see Note, Contract Remedy, supra note 244, at 117-20 (describing importance of civil suits by acquirers as supplement to criminal enforcement). Civil suits help deter insider trading because the threat of liability for damages poses an additional disincentive to illegal conduct. Exposure to liability is especially important in encouraging securities firms to monitor their employees. See infra notes 262-68 and accompanying text.

260. Plaintiffs can recover damages limited to disgorgement of the insider's profits under both an implied civil cause of action under Rule 10b-5, 17 C.F.R. $\$ 240.10 b-5$ (1989), and an express remedy under the Insider Trading and Securities Fraud Enforcement Act of 1988, 15 U.S.C. $\$ 78 t-1$ (1989) (limiting private right of action to profit gained or loss avoided). See Elkind v. Liggett \& Myers, 635 F.2d 156, 172 (2d Cir. 1980) (damages under Rule 10b-5 limited to disgorgement of profits); Wilson v. Comtech Telecommunications Corp., 648 F.2d 88, 94-95 (2d Cir. 1981) (limiting 10b-5 claims to those plaintiffs who may have transacted with insider); see also Diamond v. Oreamuno, 24 N.Y.2d 494, 496, 248 N.E.2d 910, 912, 301 N.Y.S.2d 78, 79 (1969) (upholding shareholder derivative suit under state law for disgorgement of profits made and losses avoided by insider traders); Note, supra note 220, at 641 (damages under 10b-5 are limited).

261. The limitations of the disgorgement remedy prompted Congress to provide for treble-damage fines under the Insider Trading Sanctions Act of 1984, 15 U.S.C. $\$ 78$ u-1 (1989) (treble fines). See H.R. REP. No. 910, supra note 216, at 11.

262. See Note, Contract Remedy, supra note 244, at 119 (disgorgement of employee's profits does not place much pressure on employers to prevent insider trading).

263. Recent scandals have involved the managing director of a large investment banking house, the head of mergers and acquisitions at the same house, an investment analyst, and a stockbroker. Each of these defendants traded on information which they either obtained in their own employment or received from someone else who had received it in the course of employment. See H.R. REP. No. 910, supra note 216 , at 12-13 (describing cases).

264. See 15 U.S.C. \& 78t (1989) ("controlling persons" jointly and severally liable for damages under Federal securities laws if they know or recklessly disregard facts indicating that employee is insider trading, or fail to establish procedures to prevent violations).

265. Set id.; H.R. REP. No. 910, supra note 216, at 14-15 (clear need for institutional response to insider trading problem; many securities firms have internal departments charged with policing against insider trading). 
suggest that so far such self-regulatory efforts have been largely ineffective. ${ }^{286}$

Civil liability to acquiring firms can increase the penalty for insider trading in the stock of takeover targets by an order of magnitude. Insider traders usually purchase only a fraction of a potential target's outstanding stock. Their profit opportunities are correspondingly limited. By driving up the market price for marginal shares in a target firm, however, an insider trader can increase the premium the acquirer pays for all the target firm's shares. For example, in the Litton case, the defendants' activities brought them profits of just under one million dollars while allegedly increasing the cost of the Itek acquisition by thirty million dollars. ${ }^{267}$ Potential liability for the damage suffered by acquiring firms-damage measured in millions of dollars-can not only deter individuals from illegal behavior but can increase the interest of securities firms in effectively supervising their employees to ensure that they comply with the law. ${ }^{268}$ In this fashion, the notion of price pressure can serve as a potent weapon in the ongoing battle against insider trading.

The question of who is harmed and who is helped by insider trading is inevitably difficult and complex. But as the above discussion demonstrates, an understanding of pricing mechanisms and their response to large transactions is essential to any thoughtful analysis. By supplying such an understanding, the heterogeneous beliefs hypothesis provides a valuable tool for policymakers and practioners who seek to unravel the individual and social consequences of insider trading.

\section{Shareholders' Appraisal Rights}

Corporate scholars have shown an enduring fascination for insider trading and corporate takeovers. ${ }^{269}$ In comparison, the appraisal remedy has been largely neglected. ${ }^{270}$ When viewed from the perspective of the downward-sloping demand hypothesis, however, appraisal doctrine raises some of the most interesting and important problems in corporate law.

The appraisal remedy available to shareholders who dissent from a

266. See H.R. REP. No. 910 , supra note 216 , at 15 (recent cases cast doubt on effectiveness of firm's supervisory procedures).

267. Note, supra note 220, at 601-02. On first inspection such damages may seem excessive. However, those damages reflect the actual harm imposed on acquiring firms by insider traders. See H.R. REP. No. 910, supra note 216 , at 28 (bidder damages in such cases are directly caused by insider's trading, and limiting recovery to disgorgement is inappropriate).

268. Liability to acquiring firms may add little to the incentives faced by individuals who already risk incarceration if convicted of insider trading. However, damages in such huge amounts may have great meaning to the "deep pocket" firms involved in the securities industry. See H.R. REP. No. 910, supra note 216, at 17 (broadening liability of "controlling persons" increases economic incentives to police potential inside traders).

269. See sources cited supra notes 5, 6, 214, 218.

270. But see Kanda \& Levmore, The Appraisal Remedy and the Goals of Corporate Law', 32 UCLA L. Rev. 429 (1985); Seligman, supra note 40. 
merger or other organic corporate change is fundamentally concerned with the relationship between the market price for a stock and its intrinsic value. ${ }^{271}$ That relationship is important not only to investors who hope to profit from their investments, but to judges, regulators, and scholars who increasingly rely on the presumption that in an efficient stock market, market price and value are one and the same. ${ }^{272}$ The modern "stock market exception" denying appraisal rights to shareholders whose stock is traded on a national exchange provides a powerful example of how notions of perfectly elastic demand and homogeneous investor opinion have altered the structure of corporate law.

Appraisal was unnecessary under the nineteenth-century common-law rule that required unanimous shareholder approval for organic corporate changes. ${ }^{273}$ The "rule of unanimity" effectively ensured that no shareholder ever suffered a subjective loss as a result of a merger or liquidating event: Would-be acquirers could only gain control of a target by paying a price high enough to satisfy each and every one of its shareholders. But while the rule of unanimity protected minority shareholders from being "frozen out" at prices they deemed inadequate, it posed another danger. Because a single dissenting vote could block even the most attractive merger, shareholders had an incentive to behave strategically and "hold out" to extract extra payment for their shares. ${ }^{274}$

As corporations became larger and more economically important organizations, the common law evolved to promote ease and flexibility in transfers of corporate assets by allowing majority shareholder approval of fundamental corporate changes. ${ }^{275}$ Of course, this development created new risks for minority shareholders. To compensate, the adoption of majority rule was accompanied by the legislative creation of appraisal rights in favor of those shareholders who voted against certain transactions. ${ }^{276}$ The typical appraisal statute entitles shareholders who dissent from a merger, reorganization, or sale of substantially all the corporation's assets to reject the express terms of the transaction approved by the majority and

271. Ser, e.g., DEL. CODE ANN. tit. 8, $\$ 262$ (1989) (shareholders who dissent from merger or conculidation entitled to receive fair value of shares); REviSED MODEL Business Corporation ACT $\$ 1302$ (1989) (shareholder who dissents from merger, share exchange, sale of substantially all assets, or arnendment to articles which materially and adversely affects dissenter's rights, entitled to fair value of stock).

272. S'r infra notes 311-17 and accompanying text.

273. R. Clark, supra note 158, at 443-44; L. Solomon, D. Schwartz \& J. Bauman, CorpoRations: Law and Policy 955-56 (2d ed. 1988) [hereinafter Corporations].

27.4. Comment, Valuation, supra note 40 . A second disadvantage of the rule of unanimity is that, to the extent acquisitions are made at uniform prices, the cost of acquisitions is increased to the point where many value-creating transactions may not occur. See supra notes 162-65 and accompanying text (uniform price requires payment of consumer surplus in acquisitions).

275. R. CLARK, supra note 158, at 443-44; CoRPORATIONS, supra note 273 , at 955-56.

276. CoRPorations, supra note 273 , at 955-56. 
demand payment from the corporation of the "fair value" of their shares as determined in a judicial proceeding. ${ }^{277}$

Modern financial theory has struck a direct and debilitating blow to shareholders' appraisal rights. According to the CAPM, in an efficient market the market price for a stock reflects investors' uniform estimates of its intrinsic value in terms of likely risk and return. Investors whose stock is traded in a well-developed market therefore should have no need of appraisal. They can obtain the true value of their shares by simply selling in an efficient market where the "price is right."278

State legislatures have found that argument quite persuasive. ${ }^{278}$ Beginning with Delaware in 1967, a number of states have adopted "stock market exceptions" that make appraisal available only to investors whose shares are not listed on a national exchange. ${ }^{280}$ The rationale of the stock market exception is that appraisal is an unnecessary protection for investors whose shares are traded in such well-organized, and presumably efficient, markets. ${ }^{281}$ Approximately half of all states now deny appraisal to shareholders of exchange-listed firms, and the majority of companies are incorporated in those states. ${ }^{282}$ The belief that market prices are an accurate benchmark of intrinsic value-a belief premised on the CAPM's assumptions of homogeneous investor opinion and a horizontal demand function-has therefore led to a direct and profound restriction on the ability of dissenting shareholders to seek appraisal..$^{\mathbf{2 8 3}}$

In contrast, the downward-sloping demand hypothesis provides support for traditional appraisal doctrine. First, it provides a rationale for having

277. R. Clark, supra note 158, at 443; see Seligman, supra note 40, at 831-33 (describing state appraisal statutes).

278. Sep R. ClaRk, supra note 158, at 447-48 (if market price reflects value of shares, no need for appraisal); Comment, supra note 44, at 1028, 1030 (in mid-1960's appraisal remedy came under attack by those who argued, inter alia, that appraisal gave no benefit not already available to shareholders who could sell in efficient market); Comment, Valuation, supra note 40, at 145-46 (stock market price should be basis for valuation, as efficient market prices shares at exactly their expected present value; no appraiser could do better).

279. See Note, supra note 44 , at 1032 (when states first began adopting stock market exception, argument that shareholder could receive fair value by simply selling shares in efficient market was "most persuasive" to legislatures).

280. R. ClaRK, supra note 158, at 447. The Delaware stock market exception does not apply where the dissenter would receive anything other than cash, shares in the surviving firm or other exchange-listed shares in the merger. Id. at $448 \mathrm{n} .5$.

281. Id. at 448; Seligman, supra note 40, at 844; Steinberg, Stock Exchange Exception to Appraisal and Its Ramifications for the Constitutionality of State Takeover Statules, 15 SEC. REG. L.J. 105, 105 (1987).

282. See Seligman, supra note 40, at 834-35 (25 state appraisal statutes exclude shareholders of listed firms; most firms are incorporated in those states); Note, supra note 44, at 1031-32 (two-thirds of NYSE-listed firms are incorporated in states that deny appraisal to their shareholders).

283. Interestingly, some observers have argued that the stock market exception may create an additional dilemma for dissenters who own a large block of shares, because any attempt to liquidate their holdings in the market will cause share price to decline still further. In other words, dissenters with large holdings may in fact receive less than market if they try to sell. See Seligman, supra note 40 , at 838 (noting and questioning view that dissenters' sales may depress price); Note, supra note 44, at 1044-45 (stock market exception is inadequate protection if large sales drive prices downward). That view appears to be premised on substantial demand inelasticity. 
such a remedy. ${ }^{284}$ Appraisal would be both unnecessary and irrelevant if all investors shared identical estimates of stock value: Any merger offer that met with the approval of a majority of shareholders would meet with the approval of all. ${ }^{285}$ But if shareholders hold differing opinions of the value of their stock, they can be expected to disagree on the merits of even a premium offer. Appraisal makes sense as a means of recognizing and protecting the interests of those dissenting shareholders who believe that the merger price approved by the majority is less than the actual value of their shares. ${ }^{288}$

The heterogeneous beliefs hypothesis therefore implies that the popular stock market exception to appraisal is an unwise doctrinal development. ${ }^{287}$

284. The goal of appraisal is far from apparent. See R. CLARK, supra note 158, at 444 (defeated expectations rationale for appraisal "is fraught with difficulties"); Kanda \& Levmore, supra note 270 , at 432 (conventional views of goals of appraisal are inadequate). Appraisal was traditionally justified as a means of allowing shareholders who dissent from a major corporate change to "opt out" of such developments by liquidating their interest in the corporate entity. That rationale has long since fallen into disfavor, largely because the modern shareholder is not viewed as an active participant with an interest in the detailed operations of the firm. See R. CLARK, supra note 158, at 444, 446-47 (noting arguments against appraisal in general and historical rationale in particular); Kanda \& Levmore, supra note 270 , at 434 (citing common criticisms of conventional view).

285. The exception to this rule would be the case in which a single shareholder controlled a majority interest and so would be able to force a merger at a price both majority and minority deemed inadequate. However, the appraisal remedy is not limited to this context. Indeed, the stock market exception makes appraisal unavailable to shareholders of exchange-listed firms without regard to whether merger terms are set at arms-length or by a controlling shareholder. Seligman, supra note 40 , at 836 .

286. The modern justification for appraisal is that it protects shareholders from mergers and sales at "unfairly" low prices. R. ClaRK, supra note 158, at 445; see Kanda \& Levmore, supra note 270 at 437-45 (appraisal useful where dissenting shareholders forced to sell at too low prices); supra note 284 (inadequacy of traditional justifications). This answer is troubling to efficient market theorists. If market prices are accurate, how can a merger at a premium above market be unfair? Scholars argue that merger prices may be inadequate if they do not reflect information witheld from passive shareholders, or if target management has urged shareholders to approve a sale at a low price in return for perquisites such as higher salaries or generous severance provisions. See R. CLARK, supra note 158, at 445 (management may divert part of merger price to themselves as perquisites); Brudney, supra note 54, at 66-67 ("clogged information" may lead to artificially low price); Kanda \& Levmore, supra note 270 , at 443-44 (merger price too low if management serves self-interest or does not disclose information indicating that firm has higher value). The downward-sloping demand hypothesis adds the possibility that the price paid dissenters to a merger is "too low" because it fails to reflect their more-optimistic, subjective estimate of stock value. See infra notes 296-99 and accompanying text ("fair value" as dissenter's subjective value); Kanda \& Levmore, supra note 270, at 437-41 (appraisal may serve goal of compensating more-optimistic "inframarginal" dissenting shareholders for subjective loss in merger).

Whether appraisal statutes are designed for compensating dissenting shareholders for subjective losses or for mergers tainted by undisclosed information or management misconduct, the stock market exception makes little sense unless one believes that investors in exchange-listed firms suffer smaller losses and are less likely to experience information "blockages" or management knavery. See Seligman, supra note 40 , at 841 (suggesting that appraisal be available to shareholders in exchange-listed firms when there is reason to believe that market price does not reflect value because of information shortages or management misbehavior). But see Kanda \& Levmore, supra note 270 , at 439-40, 459 (stock market exception justified as exchange-listed firms are more closely monitored for management misbehavior and have more elastic demand).

287. See infra notes 290-95 and accompanying text (commentators who critique stock market exception on the theory that market price is inaccurate measure of value); spe also Wang, supra note 2 , at $440-41 \& n .190$ (inefficiency that causes price to depart from value undermines stock market exception). 
In a world of heterogeneous beliefs, the value of the corporation's shares (as measured by their owners' subjective reservation prices) varies from shareholder to shareholder. No single shareholder's estimate can, on its face, be said to be more valid than any other's. Market price is nothing more than the equilibrium intersection of a fixed supply function with a downward-sloping demand function at that point where the leastoptimistic of the firm's current shareholders values her stock. ${ }^{288}$ That marginal shareholder's estimate may be accurate; it also may be widely off the mark. ${ }^{289}$ As a result, market price becomes an unreliable surrogate for value if demand for stock is downward-sloping. ${ }^{280}$ Certainly market price will be perceived as inadequate compensation by those shareholders who value their stock so highly that they chose to dissent to a merger at a premium above market.

The claim that market price bears no necessary relationship to actual value if investors have differing beliefs is in harmony with the reluctance of state courts to rely on market prices in appraisal cases. ${ }^{291}$ In contrast to the legislatures which adopted stock market exceptions to their appraisal statutes on the theory that market price was a reliable measure of value, state courts traditionally have turned a cold shoulder to that notion. ${ }^{282}$ That hostility is clearly evident in the Delaware Chancery's opinion in the classic 1934 case of Chicago Corp. v. Munds: ${ }^{293}$

When it is said that the appraisal which the market puts upon the value of the stock of an active corporation as evidenced by its daily quotations, is an accurate, fair reflection of its intrinsic value, no more than a moment's reflection is needed to refute it. . . . [M]arket quotations are not safe to accept as unerring expressions of value. The relation of supply to demand on a given day as truly affects the market value of a stock as it does of a commodity; and temporary

288. See supra notes $75,151-55$ and accompanying text (equilibrium market price).

289. Because short-selling is very rare, any particular stock will tend to be held by those individuals who value it most highly. See supra notes 66-73 and accompanying text. Those optimists may be insiders or skilled analysts who have superior information and superior estimates of value; alternatively, they may be overly optimistic and uninformed lay investors whose estimates of value are high simply because they are mistaken. It is difficult to tell a priori whether any particular stock's price is determined by one sort of investor or the other, much less gauge the accuracy of the price set by the least-optimistic member of this subset.

290. See Kraakman, supra note 1, at 899 n.25 (share price not equivalent to true value if investors have heterogeneous beliefs); Mayshar, supra note 56, at 127 (if investors have heterogeneous opinions and not all investors trade, it is "no longer clear what information is reflected or conveyed by equilibrium prices"; perhaps equilibrium prices reflect only the subjective valuation of marginal investors).

291. See Brudney, supra note 54, at 63-64, 78 (prevailing skepticism of Delaware courts and other tribunals concerning reliability of market price); Seligman, supra note 40, at 842 (Delaware courts "hostile" to market price as exclusive indication of value); see also Kraakman, supra note 1, at 892 ("intuition, deeply rooted in corporate law and business practice, that share prices often diverge from asset values").

292. Note, supra note 44, at 1058 (while legislators adopting stock market exception appear willing to rely on market price, courts have been reluctant).

293. 20 Del. Ch. 142, 172 A. 452 (1934). 
supply and demand are in turn affected by numerous circumstances which are wholly disconnected from considerations having to do with the stock's inherent worth. ${ }^{284}$

To scholars who rely on modern financial theory, such statements must seem archaic fallacy. But the heterogeneous beliefs hypothesis provides a theoretical foundation for the claim that stock market prices may be an unreliable measure of value. That claim seriously undermines the rationale of the modern stock market exception to appraisal..$^{205}$

In many ways, however, a downward-sloping demand function for stocks raises as many questions about the appraisal remedy as it answers. The most significant of these may be the question of what the "fair value" of a corporation's shares is. Once market price is rejected as a common standard, the concept of value becomes elusive. In a world where investors disagree sharply in their estimates of the likely return and risk of particular stocks, they cannot all be correct. But which investors are right, and which wrong? ?28 $^{28}$

One possibility is that appraisal should measure value as the subjective value each dissenting shareholder attaches to her shares. The dissenter may be a better informed or more experienced judge of intrinsic value than the shareholders who approved the transaction. For example, in a bear market dissenters may be those investors with cooler heads who can objectively estimate earnings without being swayed by market pessi-

294. Id. at 150-51, 172 A. at 455; see Paramount Communications, Inc. v. Time, Fed. Sec. L. Rep. (CCH) 194,514 at p. 93,277 (Del. Ch. July 14, 1989), affd 565 A.2d 280 (Del. July 24, 1989) (stock may have intrinsic value that differs from efficient market valuation). A similar view has been expressed by the Council of the Stock Exchange, London, which has stated that stock prices are determined by:

the actions and opinions of private and institutional investors all over the country ....

[which] are the result of hope, fear, guesswork, intelligent or otherwise, good or bad investment

policy, and many other considerations. The quotations that result definitely do not represent a

valuation of a company by reference to its assets and earnings potential.

T. Baynes, Share Valuations 22 (1973), quoled in Note, supra note 44, at 1038 n.61.

295. Uneasiness about the reliability of efficient market prices has sparked criticism of the stock market exception. See Brudney, supra note 54, at 67-68 (unexplained instances where market apparently has not reflected value undermine stock market exception); Note, supra note 44, at 1038 (market price based on unreliable information and investor irrationality). The drafters of the Model Business Corporation Act have concluded that an exception for listed stock is unwise because the market does not always accurately reflect the value of even exchange-listed stocks. See Corporations, supra note 273, at 953-54; Steinberg, supra note 281, at 105-06.

Professors Kanda and Levmore have argued that the stock market exception may reflect legislative recognition that demand for the stock of large, well-capitalized firms of the sort typically listed on national exchanges is more elastic than demand for smaller firms. Thus, a freeze-out of a dissenting minority of a large firm imposes less welfare loss than a frecze-out of minority shareholders in a smaller firm. Kanda \& Levmore, supra note 270, at 439-40; see supra notes 83-86 and accompanying text (discussing factors that influence demand elasticity). However, average takeover premiums of $50 \%$ or more are evidence of substantial inelasticity even among larger firms. See supra notes 105-06 and accompanying text. Thus, mergers of exchange-listed firms may impose large welfare losses on dissenting shareholders.

296. See Note, "Fair Value" Deternination in Corporate "Freeze-Outs," and in Security and Exchange Act Suils: Weinberger, Other, and Better Methods, 19 VAL. U.L. REv. 521, 566-70 (1985) (noting range of possible "true values" for stock, depending on who is buying and selling it). 
mism. ${ }^{297}$ A second reason to compensate dissenters for their subjective loss is that the shareholders who voted in favor of the merger or sale received payment that met or exceeded their subjective reservation prices. Perhaps the more-optimistic shareholders who comprise the upper portion of the demand function should be fully compensated as well.

Upon thoughtful consideration, however, the notion of an appraisal remedy designed to compensate dissenting shareholders fully for their perceived losses seems both undesirable and unworkable. Shareholders who believe that the value of their stock substantially exceeds both the market and a premium merger price obviously cannot expect to realize that perceived value by selling the stock in the near future. Presumably, optimists hope to profit from their opinions by holding their stock until the day their bright expectations for the firm's future are realized, either because the market price comes to agree with their assessment of the firm's value or because their optimistic expectations for dividends and other payments are met. That day may come soon, late, or not at all. An appraisal remedy that grants dissenters their subjective expectations without the slightest regard for the reasonableness of those expectations seems somehow unrealistic. ${ }^{298}$ Allowing dissenting shareholders to demand their subjective estimates of stock value also provides an incentive for virtually all shareholders dissenting from a merger to seek appraisal, creating a risk that some acquisitions might not take place even though the bidder is willing to pay a price that exceeds the aggregate the target's shareholders would demand in individually negotiated transactions. ${ }^{299}$ Finally, and perhaps most significantly, there is no reliable way to determine investors' subjective reservation prices. Direct inquiries for obvious reasons are

297. See Conard, Amendments of Model Business Corporation Act Affecting Dissenters' Rights (Sections 73, 74, 80, and 81), 33 Bus. LAw. 2587, 2595 (1978) (drafters of MBA have eliminated stock market exception on the ground that 1970's "have demonstrated again the possibility of a demoralized market in which fair prices are not available, and in which many companies publicly offer to buy their own shares because the market grossly undervalues them"); Note, supra note 44, at 1026 (bull market of 1960's persuaded many state legislators that appraisal was unnecessary protection, but low market prices of early 1970's suggest need to reconsider desirability of stock market exception).

298. See Kanda \& Levmore, supra note 270 , at 451 ("Io]ne hardly would expect an appraisal statute to call for a measurement of dissenters' idiosyncratic estimation of the corporation's future"); Seligman, supra note 40, at 844 (award of intrinsic value in excess of market value is "judicial gift" dissenter would not have received but for appraisal).

299. A virtual guarantee that dissenting shareholders could receive more for their shares in appraisal than in the merger would raise the risk that extensive (and expensive) appraisal payments would drain cash from merging firms. See R. CLARK, supra note 158, at 446 (cash drain problem). Moreover, where legal and practical considerations force bidders to make large acquisitions at a uniform price, an appraisal remedy designed to meet the subjective expectations of the most-optimistic of the target's shareholders also would increase the cost of acquisitions to the point where many efficiency-enhancing transactions might not take place. See supra notes 162-65 and accompanying text (uniform payment to shareholders creates consumer surplus and risk that value-positive takeovers will not occur). Because such efficient transactions increase overall shareholder wealth, from an ex ante perspective potential investors may prefer a "minimalist" appraisal remedy that functions as a safety net against unfair merger terms and unreliable market prices rather than one which guarantees each shareholder's hopes are met, no matter how wildly optimistic these may be. See infra notes 305-08 and accompanying text (dissenters entitled to expert rather than subjective valuation). 
likely to lead to inflated claims of value: Appraisal makes the heart grow fonder.

Perhaps appraisals of stock value should be based not on the opinions of individual dissenting shareholders, but upon some "average" investor opinion. Courts could attempt to calculate the average estimates of value held by those relatively optimistic investors who are the firm's current shareholders. ${ }^{300}$ Alternatively, courts could attempt to compute the average valuation not just of those investors who have actually purchased the stock, but of all potential investors. That group would include those individuals who have expressed their pessimistic views of the company's prospects by declining to own it.

The court determined to calculate such average valuations faces obvious practical obstacles. ${ }^{301}$ More important, there is no inherent reason why "average" opinion (whether the average of all potential investors or only current shareholders) should be more accurate than any individual dissenting shareholder's opinion. ${ }^{302}$ An average valuation culled from the opinions of many uninformed, unexperienced lay investors and relatively few informed experts may differ substantially from the best estimate of share value. ${ }^{303}$ Especially in the wake of the 1987 market crash, one can-

300. Stocks tend to be owned by those individuals who have the most optimistic opinions of the stocks' values. Thus, a firm's current shareholders are likely to overvalue their company relative to the estimates of other investors. See Miller, supra note 47, at 1154 ("Given the low level of short selling, a badly informed or excessively optimistic small group of investors can bid a stock up to a value that most investors regard as unreasonable."); supra notes 66-73 and accompanying text. The willingness of courts to grant appraisal awards in excess of market price raises the possibility that they are implicitly recognizing that the stock should be valued from the optimistic perspective of only those shareholders who would be willing to buy it. See Seligman, supra note 40, at 855 (appraisal awards almost always exceed market price for firm's stock); Comment, Valuation, supra note 40, at 135 n.65 (some courts view "fair" appraisal price as that set by "willing buyer and willing seller"). Of course, a dissenting shareholder is not likely to seek appraisal unless she believes that the merger or market price of her stock so underestimates its intrinsic value that the expense and trouble of seeking appraisal is worthwhile. Appraisal awards are therefore likely to exceed stock price.

301. Calculation of average shareholder valuation requires an accurate and truthful poll of each shareholder's subjective estimates of value. And the difficulties of polling each of the firm's actual shareholders pale in comparison to the problem of polling all potential shareholders.

302. See Verrecchia, Consensus Beliefs, Information Acquisition, and Market Information Efficikncy, 70 AM. ECON. REv. 874, 875 (1980) (no intrinsic reason why expert opinion should not be more accurate than consensus beliefs of laypersons).

303. Robert Verrecchia has developed a market model in which an efficient market incorporates differing investor opinions into a single "average" market price that is a better approximation of value than the estimate of any individual investor is likely to be. See id. at 874 (market is informationally efficient when consensus belief is at least as correct as any individual assessment). However, this model relies on at least two unrealistic assumptions. First, Verrecchia appears to assume unlimited short sales. See $2 d$. at 876 (assuming investors have unrestricted ability to buy any quantity of risky security, including, presumably, a negative quantity). Second, Verrecchia assumes that the deviation of lay opinion from the most-accurate and best-informed expert opinion is random and unbiased. Gilson \& Kraakman, supra note 3, at 584 ("no-bias" condition). In fact, investor mistake due to lay ignorance of information known to experts, or shared optimism or pessimism, is likely to be biased. See Akerlof, The Markel For "Lemons": Quality Uncertainty and the Market Mechanism, 84 Q.J. ECON. 488 (1970) (in markets where buyers are asymmetrically uninformed relative to sellers with regard to quality of goods, buyers will discount price of even high-quality goods to average value of all goods). In such a case, there is no reason to believe that an expert's opinion will not be more accurate than the market's. Gilson \& Kraakman, supra note 3, at 585. 
not avoid the suspicion that, on occasion, average lay opinion departs significantly from rational estimates of value..$^{304}$

A remaining possibility is that appraisal valuation should focus not on the opinions of lay investors or some subset of lay investors, but on the objective estimates of experts who study all available financial information. ${ }^{305}$ That appears to be the approach of many state courts in appraisal proceedings. The typical appraisal statute entitles dissenting shareholders to the "intrinsic" or "fair" value of their shares. ${ }^{306}$ Courts attempting to follow that mandate pay little attention to market prices or polls of investor opinion. Instead, they defer to professional appraisers ${ }^{307}$ who are directed to use those valuation techniques "generally considered acceptable in the financial community." ${ }^{308}$ That approach implies that stock has an intrinsic value that can differ from the merger price approved by a controlling majority, the prevailing market price, and the subjective expectations of shareholders. It is this "fair"-that is to say, expert-valuation to which dissenting shareholders are entitled.

As the question of appraisal amply illustrates, under the downwardsloping demand hypothesis the concept of stock "value" becomes problematic. Candidates for "value" include the market price at which marginal shareholders are willing to buy or sell; the varying subjective estimates attached by different shareholders; the average estimates of either existing shareholders or all potential investors; and the informed estimate of the financial expert. ${ }^{309}$ Each and every one of these may be the "correct"

304. On October 19,1987 , the Dow Jones Industrial average lost $22.6 \%$ of its value in a single day of trading. Stout, supra note 3, at 617; $c f$. Chicago Corp. v. Munds, 20 Del. Ch. 142, 150, 172 A. 452,455 (1934) ("The experience of recent years is enough to convince the most casual observer that the market in its appraisal of values must have been woefully wrong in its estimates at one time or another within the interval of a space of time so brief that fundamental conditions could not possibly have become so altered as to affect true worth. Markets are known to gyrate in a single day."). Sometimes, as in the case of market "bubbles," lay estimates of stock value seem excessively optimistic; other times, excessively pessimistic. See Kraakman, supra note 1, at 892, 899-900, 907 (market may irrationally discount value of firm's assets and uninformed traders introduce "noise" into market prices so that they depart from value; citing evidence that market values of corporations have ranged from $50 \%$ of their asset replacement costs to $105 \%$ in bull markets); Wang, supra note 2, at 361-62, 376 (suggesting that irrational markets may grossly over- or under-value stocks and that there is "fair amount of evidence" that market price departs from fundamental value; citing studies claiming that during late 1960's and early 1970's market irrationally underpriced stocks at one-half their actual value).

305. See Toms, supra note 156, at $554 \mathrm{n} .18$ (suggesting objective intrinsic value for shares that differs from subjective estimates of shareholders).

306. See Note, supra note 296, at 527 (typical statute grants intrinsic or fair value); Comment, Valuation, supra note 40 , at 134 (true or intrinsic value).

307. See Seligman, supra note 40 , at 830 (many jurisdictions use professional appraisers); Comment, Valuation, supra note 40, at 122 (Delaware courts appoint professional appraisers).

308. Weinberger v. UOP, Inc., 457 A.2d 701, 713 (Del. 1983); see Seligman, supra note 40, at 842 (Delaware by case law and New York by statute direct courts to use customary valuation methods of financial community). See generally id. at 844, 841-56 (discussing evolution of state court valuation methods, which for the most part give little weight to market price); Note, supra note 296, at $527-54$ (same).

309. Each of these estimates of value may be based on different considerations. For example, some investors may value stock according to their predictions of likely short-term changes in market price, 
value under differing circumstances. None can claim to be the only "true" value. ${ }^{310}$

That observation carries implications that go far beyond the appraisal remedy. While the heterogeneous beliefs hypothesis recognizes a range of potential values (and potentially fair prices) for a stock, the CAPM recognizes only one-the price set by an efficient market. ${ }^{311}$ The modern notion that market price and intrinsic value are identical has exerted enormous influence on both legal rules and business practice. ${ }^{312}$ For example, the proposition that no rational investor can hope to beat the market has spawned a variety of "passive" investment strategies that don't even try. ${ }^{\mathbf{3 1 3}}$ As the stock market exception to appraisal demonstrates, state law also has begun to rely on efficient market prices as adequate investor protection. ${ }^{314}$ And a similar trend is evident in the SEC's administration of the

possibly due to investor irrationality. See Stout, supra note 3, at 696-98 (speculative pricing based on short-term market changes); Wang, supra note 2, at 344 \& n.9, 346 (same). Alternatively, some investors may use orthodox portfolio theory and differ in their estimates of stock value because they differ in their estimates of future risk-discounted earnings. See supra notes 29-36 and accompanying text (portfolio theory and CAPM). Some investors may also value stock by looking to the underlying value of the firm's assets rather than current earnings. See Kraakman, supra note 1, at 901-08 (asset value of firm compared with market value).

310. Sex also Booth, supra note 39, at 638 (if shareholders have differing opinions of value, there is no single fair price for a share of stock).

311. See supra notes 27-36 and accompanying text; Gilson, supra note 15, at 858 (capital market theory says that market price is best unbiased estimate of stock value).

312. See Gordon \& Kornhauser, supra note 23, at 763 (efficient market prediction that price is equivalent to value lies at center of theoretical basis of much of corporate law); Levmore, supra note 39 , at 651 (while some areas of securities regulation appear to ignore implications of CAPM, assumption of market efficiency is "profoundly important to a variety of legal rules and requirements that govern" valuation of stocks); Wang, supra note 2, at 396-98 (describing legal commentary and rules that presume market is "fundamental-value efficient").

313. Set, p.g., supra note 101 and accompanying text (index funds). Commentators also have suggested that the CAPM's prediction that stocks are correctly priced in terms of risk and return should be incorporated into the legal rules concerning the duty of care imposed on investment managers. Sie Bines, Modern Portfolio Theory and Investment Management Law: Refinement of Legal Doctrine, 76 Colum. L. REv. 721, 763-97 (1976) (CAPM justifies wider spectrum of investment behavior than is recognized as prudent under current law); Pozen, Money Managers and Securities Rrsearch, 51 N.Y.U. L. REv. 923, 927-28 (1976) (modern financial theory supports tightening legal rules permitting fund managers to spend money on securities research); see also Note, Broker Int'estment Recommendations and the Efficient Capital Market Hypothesis: A Proposed Cautionary Legpnd, 29 STAN. L. REv. 1077 (1977) (suggesting SEC require cautionary legend on broker's confirmation notices to effect that modern financial theory suggests that securities prices already reflect all available information on value).

314. Ser supra notes 278-83 and accompanying text; see also Mills v. Electric Auto-Lite Co., 552 F.2d. 1239, 1247 (7th Cir.), cert. denied, 434 U.S. 922 (1977) (reversing trial court's finding that terms of merger were unfair to minority shareholders because consideration received exceeded market price and "when market value is available and reliable, other factors should not be utilized in determining whether the terms of a merger were fair").

The Federal "fraud on the market" doctrine also relies on the efficient market theory in predicting that fraudulent disclosure distorts market price. That theory may presume informational efficiency rather than the fundamental value efficiency of the CAPM. See supra note 33 (informational and fundamental value efficiency); In Re LTV Securities, 88 F.R.D. 134, 144 (N.D. Tex. 1980) (market price of stock reflects all available public information and therefore any material misrepresentations as well). But sex Basic, Inc. v. Levinson, 485 U.S. 224 (1988) (investors should be able to rely on market prices as indices of inherent value); id. at 251 (White, J., dissenting) (investors do not always share market's valuation). 
Federal disclosure system. The most obvious example may be the adoption of "integrated disclosure" that reduces the obligations of large, publicly held firms to provide information directly to lay investors. ${ }^{315}$ The rationale of integrated disclosure is that so long as information is made available to the experts, it will be incorporated into an efficient market price. ${ }^{316}$ Providing such information directly to shareholders is not only unnecessary-it is a waste of time. . $^{\mathbf{3 1 7}}$

In contrast, the heterogeneous beliefs hypothesis holds that market price reflects nothing more than the subjective valuation of the least-optimistic of a firm's current shareholders. ${ }^{318}$ That shareholder could be ignorant, irrational, or misinformed. Investors willing to undertake careful investigation and analysis therefore can hope to make better estimates of firms' future earnings than the estimates reflected in prevailing market prices. ${ }^{\mathbf{3 1}}$ A system of mandatory disclosure that provides information directly to individual investors can aid them in doing so; appraisal and similar doc-

315. See Proposed Amendments to Annual Report Form: Integration of Securities Acts Disclosure System, Securities Exchange Act Release No. 6,176, Exchange Act Release No. 16,496, [1980 Transfer Binder] Fed. Sec. L. Rep. (CGH) II 82,422 (Jan. 15, 1980) [hereinafter SEA Release No. 6,176]. Under the integrated disclosure system, large publicly held firms whose stock is traded in a presumably efficient market are excused from providing a great deal of information directly to investors and are permitted instead to "incorporate by reference" information contained in SEC filings of much more limited circulation. See R. Clark, supra note 158, at 750-51; L. Loss, Fundamentals of SECURITIES REGULATION 143-59 (1983).

316. Sep SEA Release No. 6,167, supra note 315 (while incorporation by reference does not ensure that investors receive information in prospectus, this is of no concern for companies whose stock prices efficiently reflect that information); Proposed Comprehensive Revision to System for Registration of Securities Offerings, Securities Act Release No. 6,235, reprinted in 20 SEC Docket 1175,1177 (Sept. 16, 1980) (investors adequately protected by efficient market price which analyzes all relevant information); see also Gordon \& Kornhauser, supra note 23, at 762-63, 810-14 (SEC's integrated disclosure premised on belief that market price reflects all available information and analysis); Wang, supra note 2, at 397 (that efficient prices reflect fundamental value of securities is underlying premise of integrated disclosure).

317. A similar assumption underlies the SEC's allowance of "shelf registration" for large issuers. Gordon \& Kornhauser, supra note 23, at 818-23.

318. See supra note 289 and accompanying text.

319. By investigating the merits of firms, investors may be able to make better estimates of stock value than the estimate reflected in current market price. See Miller, supra note 47, at 1154 (if demand is downward-sloping, investors who use skilled analysis can improve portfolio performance). At first blush, this statement may appear to be inconsistent with empirical studies in which researchers have been unable to identify short-term trading strategies that produce consistent profits. See Gilson \& Kraakman, supra note 3, at nn.24-27 (describing standard tests of ECMH). There are at least two reasons, however, why market mispricing due to heterogeneous demand may not be inconsistent with those findings. First, such tests only demonstrate that academic researchers have been unable to devise successful short-term investing strategies. That observation hardly proves that others are unable to do so. See R. BREALEY \& S. MYERS, supra note 9, at 288 (NYSE specialists and corporate managers make consistent profits); Dorfman, Pros Hit Theorists Right Where It Hurts, Wall St. J., Oct. 3, 1989 , at C1, col. 3 (investment professionals selected in special contest earned $67 \%$ over year when Dow Jones average increased $13 \%$ and portfolio selected by throwing darts returned $12 \%$ ). Second, the downward-sloping demand hypothesis suggests that investors who want to profit from fundamental analysis must be prepared to wait long enough for their predictions to be borne out in improved earnings and dividends. In the short run, there is no reason to believe that a market that over- or underestimates stock value will suddenly recognize this and adjust prices to the correct level. See Miller, supra note 47, at 1154 (profit opportunity from research increases with holding period); supra note 298 and accompanying text. 
trines that protect them from being involuntarily squeezed out at prices they deem inadequate can help them keep the fruits of their labor. But a regulatory scheme that relies on efficient stock prices as an adequate safeguard for investors provides little safety indeed. ${ }^{320}$ If investor beliefs are heterogeneous and the demand for stock is downward-sloping, state and Federal lawmakers who increasingly depend upon an efficient stock market for "investor protection" are deeply mistaken.

\section{CONCLUSION}

The participants who create securities markets, the regulators who police them, and the scholars who theorize about them must all make assumptions about stock demand elasticity and the nature of the demand function for stocks. Those assumptions often differ. Historically, investors, judges, and the SEC alike appear to have assumed that large stock transactions exerted price pressure. But with the growing acceptance of modern financial theory in general and the CAPM in particular, the notion of a horizontal demand function has exerted an influence that has changed the shape of corporate law.

While the CAPM is the dominant pricing model in corporate finance today, it is premised on the artificial assumption that all investors share the same opinion of the relative merits of different securities. This article has presented a competing model of stock pricing-the heterogeneous beliefs hypothesis-which recognizes that investors make differing estimates of stock values. In contrast to the CAPM, the heterogeneous beliefs hypothesis predicts that demand for stock should be inelastic, and the demand function, downward-sloping. Empirical evidence supports that claim.

The possibility that investor demand for stock is significantly inelastic has direct and substantial implications for corporate policy. For example, a downward-sloping demand function implies that takeover premiums may be natural market phenomena rather than evidence of efficiency gains from acquisitions. The heterogeneous beliefs hypothesis thus provides support for traditional doctrine granting target management the discretion to defend against an "inadequate" premium bid. Similarly, it undermines proposed reforms, such as a rule of managerial passivity, premised on the assumption of gains. A downward-sloping demand curve also contradicts the influential claim of efficient market theory that market prices accu-

320. Some commentators go so far as to suggest that in an efficient market any form of mandatory disclosure is unnecessary, and the existing scheme of Federal disclosure regulation should be completely dismantled. Ser Stout, supra note 3, at 639-40 (describing revisionist critique of mandatory disclosure); of. Fischel, Labor Markets and Labor Law Compared with Capital Markets and Corporatt Lau", 51 U. CHI. L. Rev. 1061, 1066 (1984) ("So long as market prices of securities reflect the relevant characteristics of particular firms-and the evidence indicates that they do-it is very hard for an investor to make what is ex ante a bad deal. By accepting the market price, investors are prolected."). 
rately reflect intrinsic value. If investor demand for stock is downwardsloping, legal rules premised on the accuracy of efficient market prices-including the stock market exception to state appraisal remedies and the SEC's integrated disclosure system-may be fundamentally unsound.

The question of whether the demand for stocks is horizontal or downward-sloping is far from answered. Additional theoretical development and empirical testing are necessary. But so long as assumptions concerning stock demand elasticity determine perspectives on appropriate regulation, the stakes are more than high enough to demand further inquiry. 